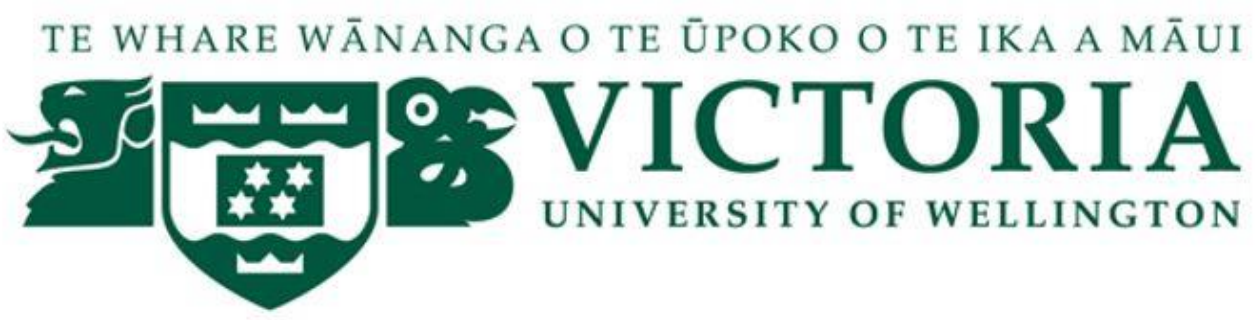

Firm Performance, Financial Constraints, and

Dual-Class Share Structure

by

Fatematuz Tamanna Ahamed

A thesis submitted to

Victoria University of Wellington

in fulfilment of the requirement for the degree of

Doctor of Philosophy in Accounting

Victoria University of Wellington

22 August 2021 


\title{
THESIS SUPERVISORS
}

\section{Tony van Zijl}

Professor of Accounting and Financial Management and Director, Centre for Accounting, Governance and Taxation Research School of Accounting and Commercial Law

Victoria University of Wellington

Wellington, New Zealand

\author{
Noor Houqe \\ Associate Professor of Accounting \\ School of Accountancy \\ Massey Business School \\ Massey University \\ Auckland, New Zealand
}




\section{DEDICATION}

This thesis is dedicated to my lovely family and my supervisors 


\section{ACKNOWLEDGEMENT}

At first, I am grateful to my creator, Almighty Allah SWT, for granting me this opportunity to enlighten myself. A Special thanks to my supervisors, Professor Tony van Zijl and Associate Professor Noor Houqe for their mentoring, patience and advice throughout the preparation of my thesis. The completion of my $\mathrm{PhD}$ journey would not have been possible without their support and guidance. I will be always grateful for the support they provided me during my hardship. My sincerest gratitude goes to the staff at SACL for providing the required resources for my study.

I am grateful for the financial support I received towards my $\mathrm{PhD}$ and my academic career. First, to Victoria University of Wellington for awarding me the Victoria Doctoral Scholarship and the submission scholarship to fund my $\mathrm{PhD}$ studies. I also thank Wellington School of Accounting and Commercial Law, for their generous conference funding and support.

I would like to thank my friends and colleagues in New Zealand. Special thanks to Fatema, Anju bhabi, Tanzila bhabi, and Shahina bhabi for not letting me feel lonely and feeding me delicious food. I am blessed to have friends like Solomon, Yinka, Jamy, Sharmistha and Sue for always encouraging me to achieve my goal and my life in Wellington would not have been so eventful and fun without them. I will always cherish those moments. 
I would also like to express my sincere gratitude to my parents, my father, Mir Hafez Ahamed and my mother Nasreen Sultana. They have supported me both spiritually and financially throughout my life and always motivated me to achieve my goals. I am blessed that my parents always gave priority to my education and tried to provide the best things for me. At last but not least, a special thanks to my dear husband (MD Asiful Alam) for giving me the shoulder to rest on whenever I needed support. 


\section{STATEMENT OF ORIGINAL AUTHORSHIP}

I hereby confirm that the work presented in this thesis is my own original work that has been carried out through the School of Accounting and Commercial Law, Victoria University of Wellington, during my candidature as a $\mathrm{PhD}$ student. I declare that the material of this thesis has not been submitted either in whole or in part for the award of any other degree or diploma at this or any other university. To the best of my knowledge and belief, it contains no material previously published or written by other persons or institutions except where due reference has been made.

\section{Fatematuz Tamanna Ahamed}




\begin{abstract}
This thesis addresses two aspects of financial constraints focusing, firstly, on the impact of financial constraints on firm performance and, secondly, on the impact of dual-class share structure on financial constraints. The first issue has been addressed in a large number of research studies, but the results are mixed. This study, therefore, conducts a meta-analysis of those earlier studies to provide a summary view of the results which, in contrast to narrative reviews of the empirical literature, provides an objective overview. The second issue examines the impact of dual-class share structures on financial constraints. The period of the global financial crisis is used to test the impact of the state of the economy on that relationship.
\end{abstract}

To examine the impact of financial constraints on firm performance, 26 empirical studies with 189 effect sizes representing listed firms have been analysed. The study finds that overall there is a positive relationship between financial constraints and firm performance. The study also shows that the set of marketbased measures of firm performance has a significant negative impact on the relationship, compared with the set of accounting-based measures. In terms of the financial constraints measure, the set of external financial constraints measures have a positive and highly significant impact on the relationship. The meta-regression analysis suggests that the choice of measure, regional difference, journal quality and publication status all have a significant impact on the relationship, and explain the variation in the association. 
To examine the impact of dual-class share structures on financial constraints the study analyses a sample of non-financial US firms over the period 2002-2018. Share structure is measured by the existence of a dual-class structure and also by excess voting rights and the proximity of the superior class shareholders ${ }^{1}$ in such structures. The study also shows that if financial constraints are measured by the WW index, irrespective of how dual-class share structure is measured, it increases the level of financial constraints. Similar results are obtained where financial constraints are measured by the $\mathrm{KZ}$ and $\mathrm{SA}$ indexes, except where dual-class share structure is measured by the proximity of superior class shareholders. The study also finds that if financial constraints are measured by the WW index, dual-class had a reduced impact during the period of the global financial crisis, thus, providing support for the propping theory. However, if financial constraint is measured by the SA index, dual-class share structure appears to have an increased impact during the GFC years.

Among the additional tests, the HM index has been used as a measure of financial constraints, and the findings show that the impact of dual-class structures on financial constraints appears to be driven by their effect on debt constraints. The study also shows that firm age moderates the impact of dualclass share structures if financial constraints are measured by the WW index. The KZ, WW, and SA indexes are based on firm characteristics and, therefore, the study also tests for an impact of dual-class structures when financial

\footnotetext{
${ }^{1}$ Superior class shareholders have greater voting rights than cash flow rights and therefore have a disproportionate influence on the major decisions of the firm.
} 
constraint is measured by a text-based index, the BLM index. However, the results do not provide evidence of an impact in that case. 


\section{TABLE OF CONTENTS}

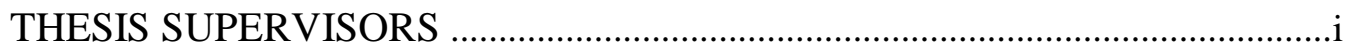

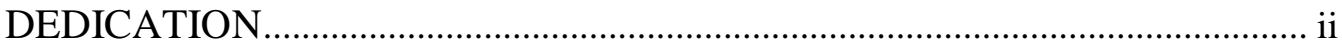

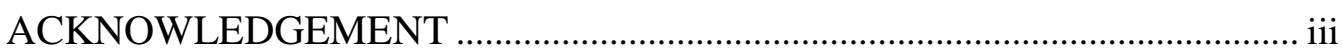

STATEMENT OF ORIGINAL AUTHORSHIP ...............................................

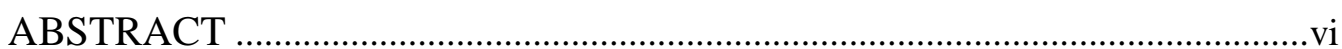

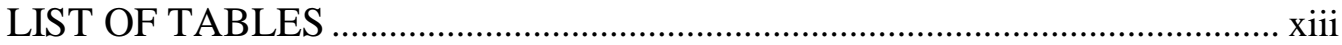

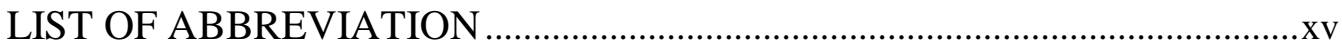

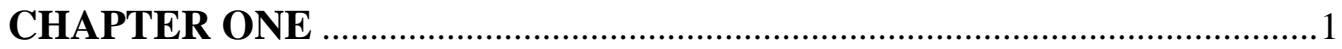

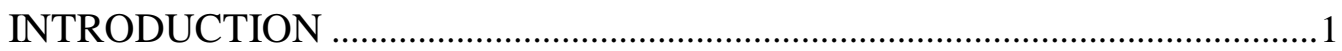

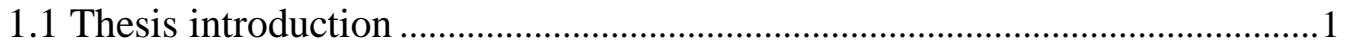

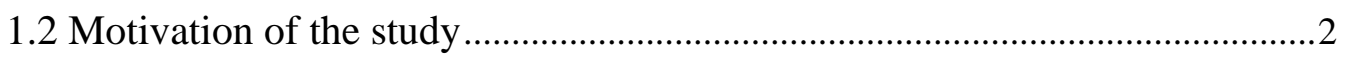

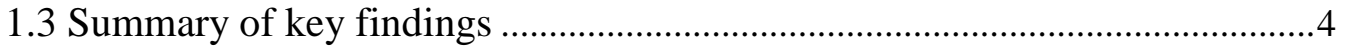

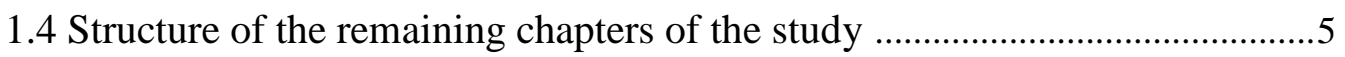

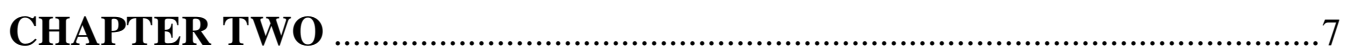

META-ANALYSIS OF THE IMPACT OF FINANCIAL CONSTRAINTS ON

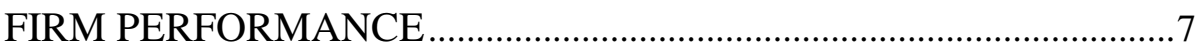

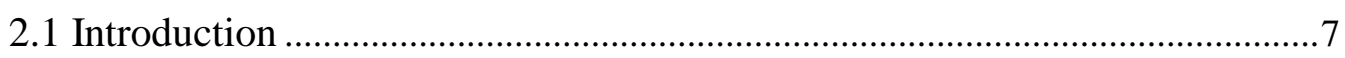

2.2 Prior research evidence and hypotheses .....................................................10

2.2.1 Impact of financial constraints ................................................................ 10

2.2.2 Development of financial constraints measure ....................................12

2.2.3 Common measures of firm performance …...........................................16

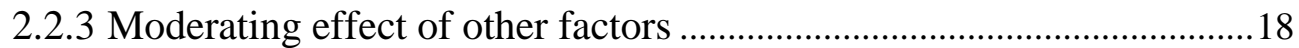

2.2.4 Association between financial constraints and firm performance.........18

2.3 Sampling procedure for meta-analysis .......................................................21

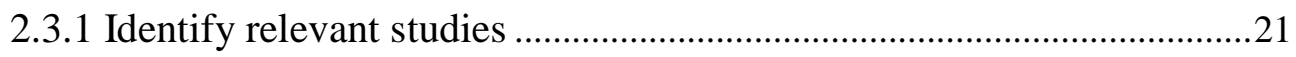

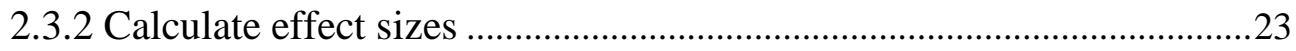


2.3.3 Estimate the weighted mean effect size and standard error. .25

2.3.4 Examine the heterogeneity of the effect sizes .......................................28

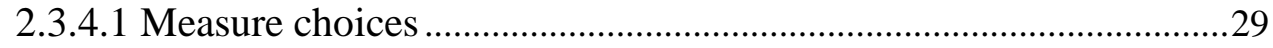

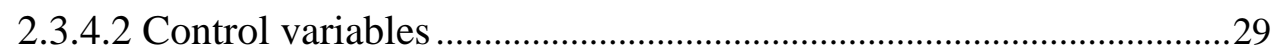

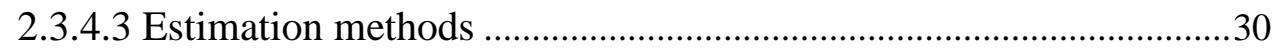

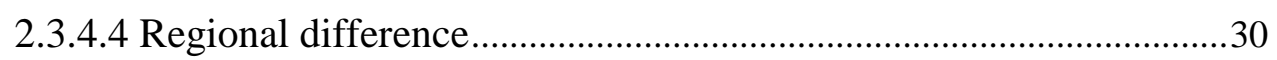

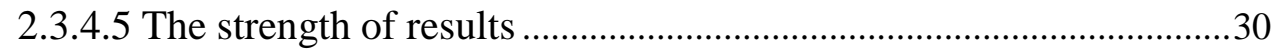

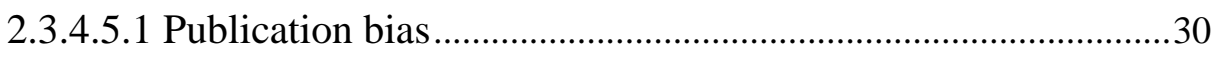

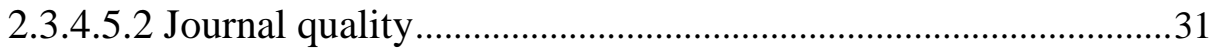

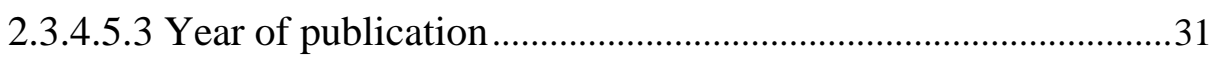

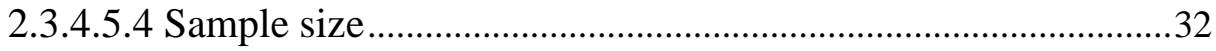

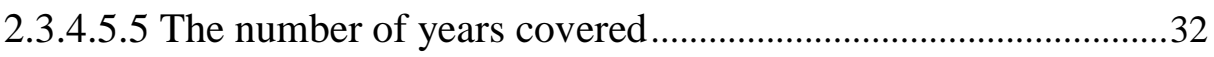

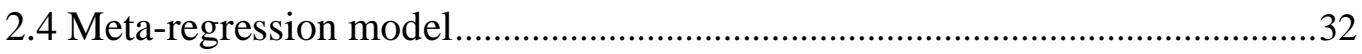

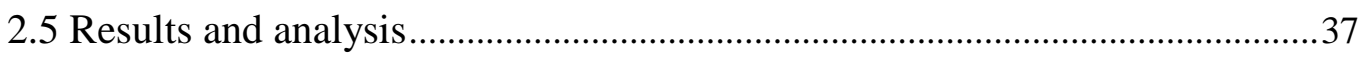

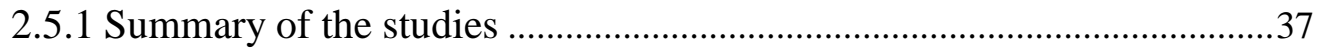

2.5.2 Distribution of effect size results by primary studies ..............................40

2.5.3 Distribution of effect size results by firm performance measure .............40

2.5.4 Distribution of effect size by financial constraints measure ....................40

2.5.5 Distribution of effect size by statistical model .........................................41

2.5.6 Distribution of effect size by different regional area ...............................41

2.5.7 Count of positive and negative effect sizes by subsections .....................41

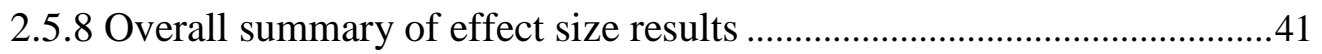

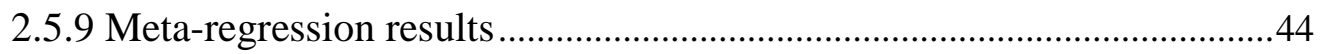

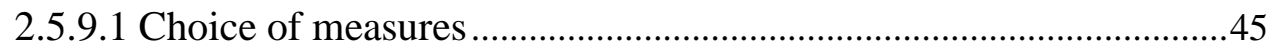

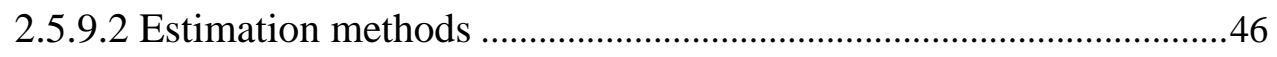

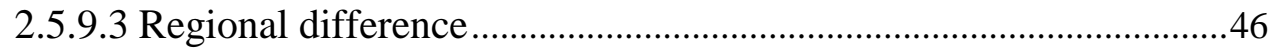

2.5.9.4 Control variables ............................................................................ 47

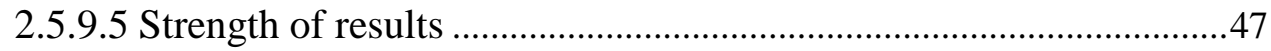

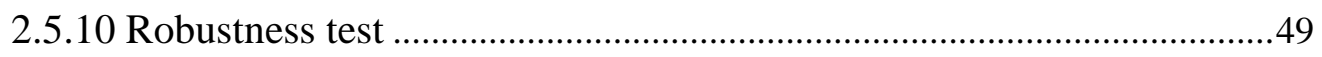

2.5.10.1 Grouping the measure choice .....................................................49 
CHAPTER THREE.

IMPACT OF DUAL CLASS SHARE STRUCTURE ON FINANCIAL CONSTRAINT .53

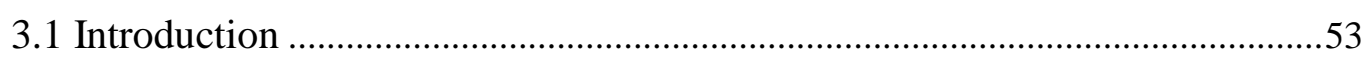

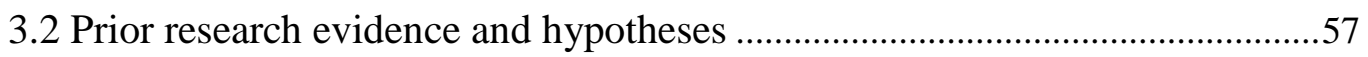

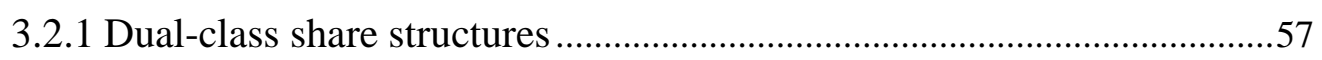

3.2.2 Global financial crisis and corporate finance .........................................61

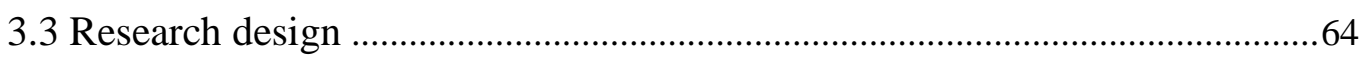

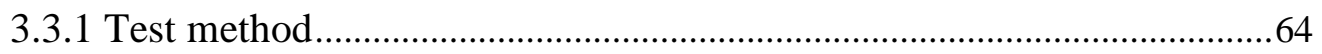

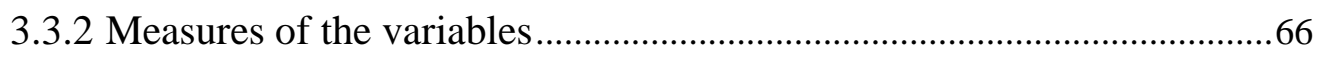

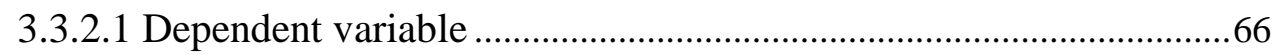

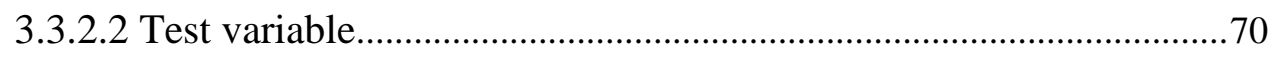

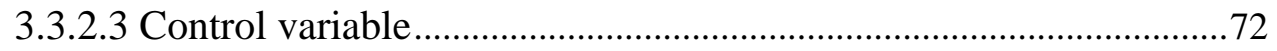

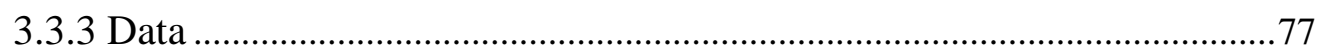

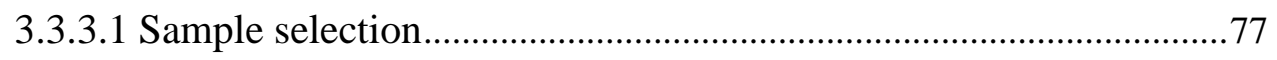

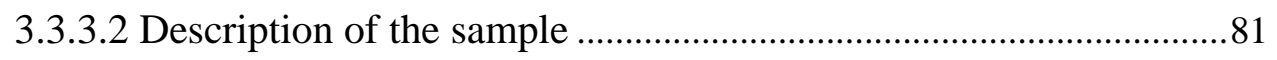

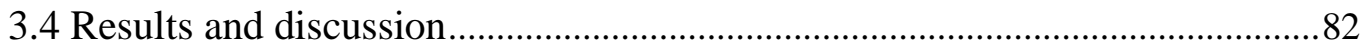

3.4.1 Descriptive statistics and correlation analysis ......................................... 82

3.4.2 Regression results for the tests of $\mathrm{H} 1, \mathrm{H} 2$, and $\mathrm{H} 3$ ….............................. 87

3.4.3 Regression results for the tests of $\mathrm{H} 4, \mathrm{H} 5$, and $\mathrm{H6}$..................................94

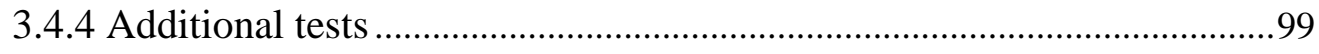

3.4.4.1 HM index as a measure of financial constraints ................................99

3.4.4.2 Moderating impact of firm age...........................................................106

3.4.4.3 BLM index as a measure of financial constraints ............................111

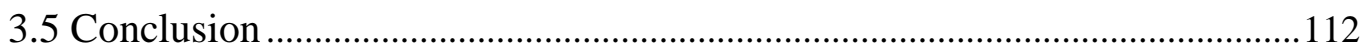

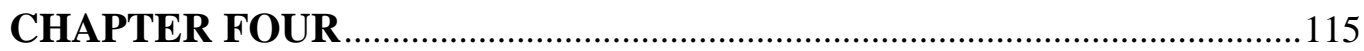


CONCLUSION TO THE THESIS

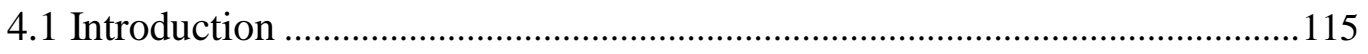

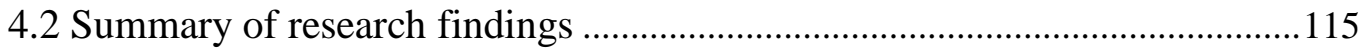

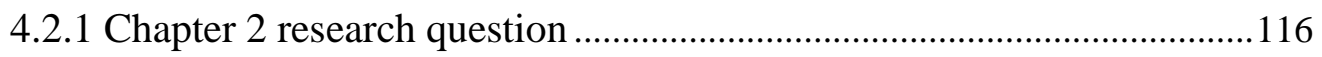

4.2.2 Chapter 3 research question ................................................................116

4.3 Contribution and implication of the thesis ...................................................118

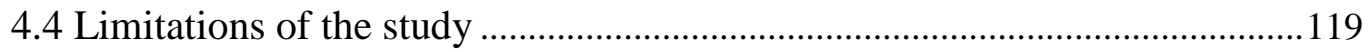

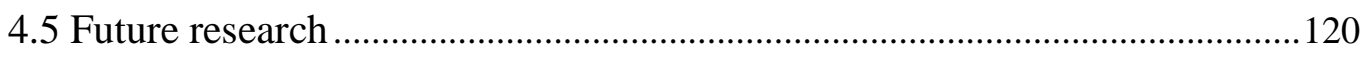

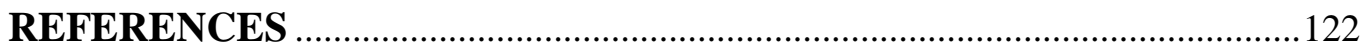




\section{LIST OF TABLES}

Table 2.1: Measurements of financial constraints used in the literature

Table 2.2 Panel A: Description of formulas for the meta-analysis assuming fixed effect model ........................................................... 26

Table 2.2 Panel B: Description of formulas for the meta-analysis assuming random effect model

Table 2.3: Variable definitions

Table 2.4 Panel A: Summary of studies included in the meta-analysis............ 38

Table 2.4 Panel B: Journal quality rankings included in meta-analysis ........... 39

Table 2.5 Panel A: Within study mean effect size (ES) by primary studies..... 42

Table 2.5 Panel B: Summary of ES results by measure of firm performance.. 43

Table 2.5 Panel C: Summary of ES results by measure of financial constraints

Table 2.5 Panel D: Summary of ES results by statistical model

Table 2.5 Panel E: Summary of ES results by regional difference

Table 2.5 Panel F: Count of positive and negative effect sizes by subsections 43

Table 2.5 Panel G: Summary of ES results and Publication biased test.......... 44

Table 2.6: Random effect meta-regression .................................................... 48

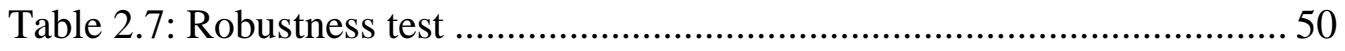

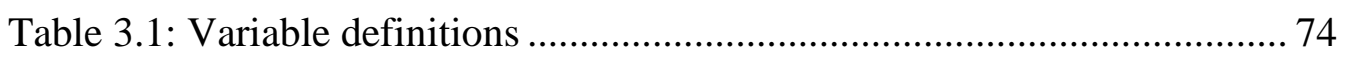

Table 3.2 Panel A: Sample selection procedure .......................................... 80

Table 3.2 Panel B: Distribution of sample by year....................................... 81

Table 3.2 Panel C: Distribution of sample by industry .................................. 82

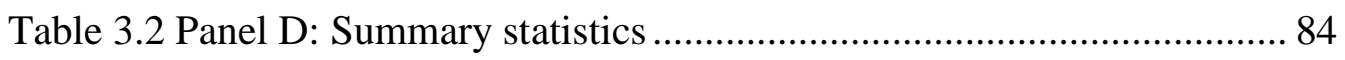

Table 3.2 Panel E: Summary statistics by dual-class ..................................... 85

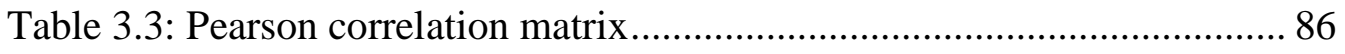

Table 3.4: Results for dual-class share structure on financial constraints ........ 91

Table 3.5: Results for the impact of voting wedge on financial constraints.... 92

Table 3.6: Results for the impact of the proximity of superior-class shareholder on financial constraints 93 
Table 3.7: Results for the impact of the global financial crisis on the association between financial constraints and dual class share structure

Table 3.8: Results for the impact of the global financial crisis on the association between financial constraints and voting wedge

Table 3.9: Results for the impact of the global financial crisis on the association between financial constraints and the proximity of superior class shareholder

Table 3.10: Results for the association between the dual class share structure and financial constraints using HM Index

Table 3.11: Results for the association between the voting wedge and financial constraints using HM Index 104

Table 3.12: Results for the association between the proximity of superior-class shareholder and financial constraints using HM Index 105

Table 3.13: Results for the moderating impact of the firm age on the relationship between dual class share structure and financial constraints

Table 3.14: Results for the moderating impact of the firm age on the relationship between voting wedge and financial constraints

Table 3.15: Results for the moderating impact of the firm age on the relationship between the proximity of superior shareholder and financial constraints. 


\section{LIST OF ABBREVIATION}

\begin{tabular}{|c|c|}
\hline Abbreviation & Meaning \\
\hline $\mathrm{ABDC}$ & Australian Business Deans Council \\
\hline ES & Effect Size \\
\hline $\mathrm{SE}$ & Standard Error \\
\hline GFC & Global Financial Crisis \\
\hline KZ INDEX & Kaplan and Zingale's index \\
\hline WW INDEX & Whited and Wu's index \\
\hline SA INDEX & Size and Age index \\
\hline HM INDEX & Hoberg and Maksimovic's index \\
\hline BLM INDEX & $\begin{array}{l}\text { Bodnaruk, Loughran and McDonald's } \\
\text { index }\end{array}$ \\
\hline ROA & Return on Asset \\
\hline ROE & Return on Equity \\
\hline GMM & Generalized Method of Moments \\
\hline $\mathrm{FE}$ & Fixed effect \\
\hline REMR & Random-Effects Meta-Regression \\
\hline PSM & Propensity Score Matching \\
\hline
\end{tabular}




\section{CHAPTER ONE}

\section{INTRODUCTION}

\subsection{Thesis Introduction}

This thesis examines the impact of financial constraints on firm performance using meta-analysis and also examines the impact of dual-class share structure on financial constraints.

A large number of empirical studies have addressed the effects of financial constraints on firm performance, but the results have been mixed. The first study, therefore, conducts a meta-analysis to provide an overall view of the results. In contrast to narrative reviews, meta-analysis provides an objective summary. The question addressed is:

What is the overall impact of financial constraints on firm performance?

The second study examines whether dual-class share structures affect financial constraints. Share structure is measured by the existence of a dual-class structure, and also by excess voting rights and the proximity of the superior class shareholders in such structures. In addition, the study examines the impact of the state of the economy on the relationship. To analyse these issues, the study uses a sample of non-financial US firms from the period 2002-2018, and uses the 
global financial crisis period as an example period to test the impact of the state of the economy.

Thus, the primary research questions for the second study are:

What is the impact of dual-class share structures on financial constraints? Does the impact change during the global financial crisis period?

\subsection{Motivation of the Study}

The motivation for the meta-analysis study derives from the variation in results obtained from the large body of empirical studies that has provided evidence on the impact of financial constraints on firm performance. Some researchers have found a positive relationship (for example, Kaplan and Zingles, 1997; Li, 2011; Livdan, Sapriza, and Zhang, 2009; Stikkelman, 2010; Whited and Wu, 2006; Zhao, 2016) but other researchers have found a negative relationship between financial constraints and firm performance (for example, Campello and Chen, 2010; Chan, Chang, Faff, and Wong, 2010; Chen and Wang, 2012; Hennessy, Levy, and Whited, 2007; Lamont Polk, and Saaá-Requejo, 2001). Therefore, it is important to use meta-analysis to summarize the research findings and to investigate the heterogeneous factors (such as; different measure choice, different selection of control variables, different estimation methods used in the studies, different regional areas investigated in the studies, and different strength of results) that influence the relationship between financial constraints and firm performance. 
The motivation for the second study stems from the emerging enquiry into the impact of dual-class share structures on financial constraints and the ongoing debate on the effects of the global financial crisis. Owing to the increase in the number of dual-class IPOs, the impact of dual-class structure on corporate governance and investor protection became an important topic for research. According to Ritter (2017), there were a total of 46 significant dual-class share IPOs in the US from 2006 to 2010, and this increased in later years ${ }^{2}$. Facebook's 2018 IPO $^{3,4}$, with uneven share structure, ignited significant popular interest in dual class structures. There are a number of studies that have argued against dual-class share structures, citing reduced investor protection resulting from the disproportionate share structure 5 .

Friedman, Johnson, and Mitton (2003) show that there is a positive change in the behaviour of superior shareholders during a crisis and this affects firm performance. However, a number of researchers find an overall negative impact on performance from the global financial crisis (Brunnermeier, 2009; Erkens, Hung, and Matos, 2012; Moore and Mirzaei, 2016). Thus, the study investigates the impact of the global financial crisis on the association between dual-class share structures and financial constraints.

2 Ritter (2018). Initial Public Offerings: Updated Statistics. Available at https://site.warrington. ufl.edu/ritter/files/2018/07/IPOs2017Statistics_July11_2018.docx

${ }^{3}$ Kerber (2018). "Outside Investors Rebuke Facebook Vote Structure, Tallies Show." Reuters, 5 June 2018

${ }^{4}$ In 2019, the founder of Facebook Inc held $58 \%$ of the voting rights by holding $75 \%$ of Superior class share.

${ }^{5}$ Further discussed in literature review. 


\subsection{Summary of Key Findings}

The meta-analysis of the association between financial constraints and firm performance shows that, overall, there is a positive relationship between financial constraints and firm performance. However, there is significant variation in effect size (both in sign and significance) for the relationship between financial constraints and firm performance. In addition, metaregression results suggest that choice of measure, regional difference, journal quality, and publication status have a significant impact on the relationship. The study also reveals that the set of market-based measures of firm performance has a negative and significant impact on the relationship, compared with the set of accounting-based measures. Among the financial constraints measures, external financial constraints-based measures have a positive and highly significant impact on the relationship. Additionally, the result is stronger for the cross country studies and those based on Asia and Europe.

The results of the study on the impact of dual-class share structures on financial constraints, shows that where dual class structure is measured by the existence of dual class or voting wedge, dual-class share structure increases financial constraints, whether financial constraints are measured by the KZ, WW or SA indexes. However, where proximity of the superior class shareholders is used as the measure of dual-class, then dual-class share structure increases financial constraints only if financial constraints are measured by the WW index. The study also find that if financial constraints is measured by the WW index, dualclass had a reduced impact on financial constraints during the period of the 
global financial crisis, thus, providing support for the propping theory. However, if financial constraints are measured by the SA index, dual-class share structure appears to have an increased impact on financial constraints during the GFC years.

Among the additional tests, the HM index is used as a measure of financial constraints and the findings show that the impact of dual-class structures on financial constraints appears to be driven by the effect on debt constraints. The study also provides evidence that firm age moderates the impact of dual-class share structures on financial constraints if financial constraints are measured by the WW index. The KZ, WW, and SA indexes are based on firm characteristics, and thus, the study also uses the BLM index, a text based index, to test for the impact of dual class structures on financial constraints. However, the results are not significant.

\subsection{Structure of the Remaining Chapters of the Study}

Chapter two reports on the meta-analysis of the association between financial constraints and firm performance. Section 2.1 provides the introduction to the chapter. Section 2.2 reviews the research evidence on the impact of financial constraints on firm performance and proposes the hypotheses. Sections 2.3 and 2.4 describes the meta-analysis procedure and the meta-regression model respectively. Section 2.5 provides the results and analysis of the study and Section 2.6 concludes the chapter. 
Chapter three reports on the impact of dual-class share structure on financial constraints. The chapter begins with an introduction in section 3.1. Section 3.2 reviews the research evidence and states the hypotheses. Sections 3.3 provides details of the test methodology and the study sample. Section 3.4 discusses the empirical results and presents additional tests. Finally, Section 3.5 concludes the chapter.

Chapter four provides the conclusion to the thesis. Section 4.1 provides the introduction to the chapter. Section 4.2 presents a summary of the research findings and section 4.3 sets out the contributions of the thesis. Section 4.4 discusses the limitations of the study. Finally, section 4.5 discusses the opportunities for future research. 


\title{
CHAPTER TWO
}

\section{Meta-analysis of the Impact of Financial Constraints on}

\author{
Firm Performance
}

\subsection{Introduction}

This study conducts a meta-analysis of the impact of financial constraints on firm performance. Some researchers have found a positive relationship between financial constraints and firm performance (for example, Kaplan and Zingales, 1997; Li, 2011; Livdan et al., 2009; Stikkelman, 2010; Whited and Wu, 2006; Zhao, 2016) while other researchers have found a negative relationship (for example, Campello and Chen, 2010; Chan et al., 2010; Chen and Wang, 2012; Hennessy et al., 2007; Lamont et al., 2001). The difficulty in interpretation of these varied results is compounded by the changes that have taken place over time in corporate financing behaviour, and the variation in results hampers progress in understanding the extent, relevance, and drivers of the relationship. Therefore, it is useful to attempt to reconcile the differences found across different studies and to provide an objective conclusion about the financial constraints - firm performance relationship. ${ }^{6}$

6 Khalif and Chalmers (2015) encourage accounting researchers to do a meta-analysis, as there is a scarcity of meta-analytic reviews in some accounting fields. 
As indicated above, numerous researchers have examined the effect of financial constraints on firm performance but, to date, the empirical evidence has been mixed. The studies have used different measures for the degree of financial constraints and for firm performance. Therefore, it is important to encode the statistical findings and, thus, to provide a consistent basis on which to compare the different studies. Lipsey and Wilson (2001), mention the following primary advantages of meta-analysis. Meta-analysis (1) is a useful technique for summarizing research findings; (2) it represents key study findings in a sophisticated manner by encoding the strength and direction of each study; (3) it allows an analytically precise examination of the relationship between study findings; and (4) it provides an organized way of handling detailed information from a large number of research findings under review.

This study uses meta-analysis to provide an overall view of the results found in the individual empirical studies. Meta-analysis pools the results reported in individual studies to enable a generalisation to be made and to improve both statistical power and validity that may be absent from individual studies. No paper has come to notice that has used meta-analysis to investigate the impact of financial constraints on firm performance. This is a significant gap in the literature as a number of studies have shown that the economic consequences of financial constraints influence investment policy, which in turn, may affect firm performance. As firm performance is a key interest for potential investors and policy makers it is important to investigate the factors influencing performance. 
Although many researchers have investigated the impact of financial constraints, the results of the studies have been mixed in terms of the direction of the impact of financial constraints on firm performance. Therefore, the findings of this study have the potential to indicate the impact of the access to finance on firm performance, and to investigate the factors that cause differences in results reported in empirical studies.

This study follows several meta-analysis papers, including those of Ahmed and Courtis (1999), Orlitzky, Schmidt, and Rynes, (2003), Ahmed, Chalmers and Khlif (2013), Wang and Shailer (2015), and van Essen, Carney, Gedajlovic, and Heugens (2015), Hay and Knechel (2017), Wang and Shailer (2018), and Opare, Houqe and van Zijl (2019). Based on these papers, the differences observed across the studies analysed may arise from a variety of factors, including population differences, sampling error, or bias. To investigate this, at first, the relevant theoretical papers are systematically reviewed. Then meta-analysis techniques are used to integrate the different empirical results and to analyse the relationship between financial constraints and firm performance. Finally, the study examines the differences in research design which may cause differences in the empirical results.

The rest of this study is structured as follows. The next section reviews the research evidence on the impact of financial constraints on firm performance and sets up the hypotheses. After that, the meta-analysis procedure and the meta- 
regression model is described. The next section presents the results and analysis of the findings. The final section concludes the study.

\subsection{Prior Research Evidence and Hypotheses}

This section reviews the literature related to the impact of financial constraints, discusses the different measures of financial constraints, and of firm performance, and also reviews the literature on the impact of financial constraints on firm performance.

\subsubsection{Impact of financial constraints}

Financial constraint refers to the accessibility of funding to undertake desired investments. According to Chen (2016), financial constraints reflect the difficulties a company faces when it has funding needs, but cannot successfully obtain funding. Financial constraints may occur owing to credit constraints, corporate tax, inability to borrow, inability to issue equity, unavailability of bank loans or illiquidity of assets (Cheng, Ioannou, and Serafeim, 2014; Hennessy and Whited, 2007; Lamont et al., 2001).

In a market with no frictions, investors and managers would have access to the same quality of information about firms' financial activities. However, in the real world, the cost of external financing could be higher than the costs of internal funding (Myers and Majluf, 1984; Pellicani and Moccellin, 2010), and 
some financial market frictions might prevent a firm from funding all desired investments. However, it is important to note that this study focuses on financial constraints, not financial distress. ${ }^{7}$

Prior research shows that financial constraints both influence, and are influenced by, investment decisions, financing, dividend policy, and corporate value (Chen, 2016). According to Musso and Schiavo (2008), financial constraints play a significant role in determining the probability of firm survival, as access to external funds increases firm growth in the short run. Similarly, Aghion, Fally, and Scarpetta (2007), show the impact of financial development on firm entry, size at entry, and post-entry performance of new firms. They find that access to external finance has a significant impact on the entry of small firms, and that it improves market selection by allowing small firms to compete on an equal footing. Winker (1999), and Becchetti and Trovato (2002) also demonstrate a similar result, and argue that the perceived credit constraint limits innovation expenditures and overall investment. In another study, Carpenter and Petersen (2002) analyse the growth of 1,600 small US firms, and find that the availability of internal finance certainly constrains asset growth. They argue that firms able to raise more external funds than others manage to grow faster. Thus, the level

\footnotetext{
${ }^{7}$ Senbet and Wang (2012) note that distressed firms are unable to keep the promises made to creditors. Therefore, financial distress refers to the inability of a company to meet its financial obligations as they mature (Beaver, Correia, and McNichols, 2011), whereas financial constraints refers to the unavailability of funding for desired investment.
} 
of attention that researchers have given to financial constraints over the past decade is to be expected.

\subsubsection{Development of financial constraints measures}

The traditional approach to identifying financially constrained firms dates back to the late 1980s. Fazzari, Hubbard, Petersen, Blinder, and Poterba (1988) demonstrate that investment spending varies with the availability of internal funding (cash flow) when firms face financial constraints. Some studies have identified several problems with the finding of Fazzari et al. (1988). In particular, Kaplan and Zingales (1997) express severe doubt about investment-cash flow sensitivity as a measure of financial constraints, and they introduce a new index to measure financial constraints, the $\mathrm{KZ}$ index, based on five factors, or indicators, of external funding barriers. The five factors are cash flow, Tobin's Q, debt to capital, dividends to book assets, and cash.

\footnotetext{
Almeida, Campello, and Weisbach (2004) construct an alternative index, the ACW index, based on a firm's payout ratio, size, bond rating, and commercial paper rating. Whited and $\mathrm{Wu}$ (2006) propose yet another index, the WW index, based on six firm characteristics associated with financial constraints, such as firm size, industry sales growth, firm sales growth, cash flow, dividends, and leverage.
} 
Hadlock and Pierce (2010) argue that only firm size and age should be considered. The authors dispute the validity of the $\mathrm{KZ}$ index and the $\mathrm{WW}$ index, and provide evidence that some of the factors included in the indexes are not significantly related to constraints. Although two of the factors, leverage and cash flow, from the $\mathrm{KZ}$ and the WW indexes, are significantly related to financial constraints, these variables may lead to under-detection of the presence of constraints in firms with low leverage or low cash flow. ${ }^{8}$ Hadlock and Pierce (2010), thus, propose a new index, the SA index, and show that small and young firms are more financially constrained compared with large firms and old firms.

Arguing for an entirely different approach, Hoberg and Maksimovic (2014) developed a text-based measure for financial constraints. The authors consider that use of words such as 'delay,' 'abandon,' 'curtail' and 'construction,' in the 10-K Liquidity and Capital Resources subsection of Management Discussion and Analysis indicates the presence of financial constraints. They construct four scores based on continuous constraint variables for each firm (hereafter, the "HM text-based measure"). These are the "Delay Investment Score", the "Equity Focus Delay Investment Score", the "Debt Focus Delay Investment Score", and the "Private Placement Focus Delay Investment Score."

The authors score delayed investment based on the average vocabulary (list of words mentioned above) used by firms, while controlling for the presence of

${ }^{8}$ See Hadlock and Pierce (2010) for more details. 
standard text. Bodnaruk, Loughran, and McDonald (2015) show that the more managers are concerned about future financial constraints, the more they will disclose through text in the 10-K filings and they, therefore, extend the HM textbased approach to compile a list of 184 constraint related words from all 10-K filings, from which the commonly used words are: 'required', 'obligations', 'impairment', 'covenants', 'requirements', 'permitted', 'comply', 'imposed'. The authors use the percentage of these words as a measure of financial constraints, the BLM index. However, the Hoberg and Maksimovic (2014) and the Bodnaruk et al. (2015) text-based measures of financial constraints are comparatively new and have not been commonly used. A summary of the proxies used for financial constraints in the literature is given in Table 2.1. 
Table 2.1: Measures of financial constraints used in the literature

\begin{tabular}{|c|c|}
\hline Paper & Measure of Financial Constraints \\
\hline Fazzari et al. (1988) & Dividend payout ratio \\
\hline $\begin{array}{l}\text { Devereux and Schiantarelli } \\
\text { (1990) }\end{array}$ & Age, Size \\
\hline Hoshi et al. (1991) & Group membership \\
\hline Bond and Meghir (1994) & Dividends over capital stock + share issues \\
\hline Chirinko and Schaller (1995) & Age, Concentration of Ownership, Group membership \\
\hline $\begin{array}{l}\text { Gilchrist and Himmelberg } \\
\text { (1995) }\end{array}$ & Dividend payout ratio, Size, Bond rating \\
\hline Kaplan and Zingales (1997) & $\begin{array}{l}\text { Cashflow ratio, Tobins' } \mathrm{Q} \text {, leverage, dividend payout } \\
\text { ratio, cash holding ratio (KZ index) }\end{array}$ \\
\hline Kadapakkam et al. (1998) & Size \\
\hline Lamont et al. (2001) & KZ index \\
\hline Becchetti and Trovato (2002) & Interest expenditure based on survey data \\
\hline Campa and Shaver (2002) & Group membership \\
\hline Baker et al. (2003) & KZ index \\
\hline Almeida et al. (2004) & $\begin{array}{l}\text { Dividend payout ratio, size, bond rating, commercial } \\
\text { paper rating (ACW index) }\end{array}$ \\
\hline Greenaway et al. (2005) & Liquidity, Credit rating \\
\hline Cleary (2006) & Size, dividend payout ratio \\
\hline Whited and Wu (2006) & $\begin{array}{l}\text { Cashflow, Dividend policy, Leverage, Size, Sales } \\
\text { growth }\end{array}$ \\
\hline Hennessy et al. (2007) & KZ index, WW index \\
\hline Hadlock and Pierce (2010) & SA index \\
\hline Chan et al. (2010) & $\begin{array}{l}\text { Current ratio, financial slack (Slack), leverage, fixed } \\
\text { charge coverage, net income, and sales growth (ZFC } \\
\text { index) }\end{array}$ \\
\hline $\begin{array}{l}\text { Campello and Chen (2010), } \\
\text { Stikkelman (2010), Chen and Wang } \\
\text { (2012) }\end{array}$ & $\mathrm{KZ}$ index, WW index \\
\hline Hoberg and Maksimovic (2014) & Text based measure (HM index) \\
\hline
\end{tabular}




\begin{tabular}{|l|l|}
\hline Caballero et al. (2014) & WW index \\
\hline Khatami et al. (2015) & KZ index \\
\hline Bodnaruk et al. (2015) & Text based measure ( BLM index) \\
\hline Zhao (2016) & KZ index \\
\hline Jin et al. (2018) & $\begin{array}{l}\text { Capital expenditure, cash flow to Capital expenditure, } \\
\text { asset tangibility }\end{array}$ \\
\hline
\end{tabular}

\subsubsection{Common Measures of Firm Performance}

Return on assets (ROA), return on equity (ROE), stock return, Tobin's Q, market to book, market value, and sales growth are the commonly used measures of firm performance in corporate finance studies (see, for example, Chari, Chen, and Dominguez, 2012; Firth et al., 2006; Kim and Yoon, 2007; Lin, Liao, and Chang, 2011c; O'connell and Cramer, 2010; Ting, 2008; Wei, 2007; Xu, Zhu, and Lin, 2005). Return on assets and return on equity are measures that indicate the earnings produced from capital investment and the earnings produced from equity, and are the most common accounting-based performance measures. Change in sales is another indicator of firm performance and shows the growth in sales over a particular period. Standard market performance measures include Tobin's Q, stock return, market to book, and market value. Tobin's Q is derived from the value maximisation problem of the firm, and the Q statistic captures the extra benefit the firm obtains from an additional unit of capital (Bond and Soderbom, 2013; Hennessy et al., 2007; Tobin, 1969) 
The stock market return is a market-based measure that shows the relative change in the market price of the stock over a period of time. Different types of stock return measure are used, for example, excess return, measures based on the Capital Asset Pricing Model, the Fama and French four and five factor models, buy and hold abnormal return, cumulative abnormal return, and Carhart abnormal return. Another measure, the market-to-book ratio, is calculated by dividing the current closing price of the stock by the current quarter's book value per share. Here, the market value is the current stock price of all outstanding shares and the book value is the amount of the firm's assets minus its liabilities. The market to book ratio is used to compare a business's net assets that are available, in relation to the market price of its stock. Market value also represents the firm's financial position and can provide an indication of investors' perceptions of the firm's prospects.

These different measures of firm performance can result in apparently different impacts of financial constraints on firm performance. Wang and Shailer (2015) note that accounting measures use historical data, and are subject to managerial manipulation and differences in accounting procedures, whereas market performance measures are more forward-looking and reflect investors' expectations. Demsetz and Villalonga (2001) argue that market performance measures are affected by investor sentiment but are, nevertheless, more likely to be reliable than historical accounting measures. Therefore, it is important to analyse the different measures separately and, also, to test whether the choice of 
accounting or market performance measures influences the relation between financial constraints and firm performance.

\subsubsection{Moderating Effect of other Factors}

In addition to the choice of measures for firm performance and financial constraints, there are other factors that demonstrate the variation across the studies on the impacts of financial constraints on firm performance. For example, different selection of control variables, different estimation methods used in the studies, different regional areas investigated in the studies, and different strength of results (publication status, journal quality, year of publication, sample size, and number of years covered) could be the reason for the mixed results across the studies. Therefore, it is important to investigate the moderating effect of all these variables in addition to the choice of measures for firm performance and financial constraints.

\subsubsection{Association between Financial Constraints and Firm}

\section{Performance}

Numerous prior studies provide substantial evidence that financial constraints have a significant role in strategic decision-making by affecting the firm's investment decisions directly (Cleary, 1999; Cleary, Povel, and Raith, 2007; Kaplan and Zingales, 1997; Stein, 2003). Kaplan and Zingales (1997) find that the investment and firm value relationship is more sensitive in constrained firms. 
Baker, Stein, and Wurgler (2003) split their sample into different quintiles according to the $\mathrm{KZ}$ index, and find extensive evidence that, compared with the least constrained firms, the most constrained firms are three times more sensitive in the investment to Q relationship. In contrast, Cooper and Ejarque (2003) show that financial frictions have no impact on the investment - profitability relationship. Almeida and Campello (2007), show that the degree of tangibility of constrained firms' assets increases the sensitivity of cash flow to investment.

Almeida et al. (2004) find that only financially constrained firms focus on liquidity to maximise firm value, which shows the direct link between financial constraints and firm value. Using the simulated method of moments, Hennessy and Whited (2007) provide evidence that, for both small and large firms, financial constraints have a negative impact on firm value. The authors argue that financially constrained firms face higher costs of equity and bankruptcy, and this limits a firm from achieving the desired capital structure. Financially constrained firms forego valuable investment opportunities, and this decreases firm value. In contrast to the Hennessy and Whited (2007) findings, Stikkelman (2010) finds that as financial constraints increase, so does firm value. The author investigates the effect of financial constraints on the value of non-financial publicly traded firms in France according to firm size. Stikkelman (2010) shows that the magnitude of the positive relationship between financial constraints and firm value is stronger for large firms compared with medium-sized firms. The 
author also argues that the relationship differs across countries owing to differences in the institutional characteristics of different countries.

There are also mixed results for the impact of financial constraints on stock return. The debate begins with Lamont et al. (2001), who find that financial constraints decrease stock returns for growing manufacturing firms. Chan et al. (2010) develop an index to measure financial constraints and provide evidence of a negative association between financial constraints and stock returns. Bavarsad, Sinaei, and Delavaripour (2013) and Campello and Chen (2010) find strong support for this finding. Bavarsad et al. (2013) also show that firm size is the primary driver of the negative relationship between financial constraints and stock return for firms listed on the Tehran stock exchange. In contrast, Whited and $\mathrm{Wu}$ (2006) find that more financially constrained firms earn higher stock returns on average. The authors argue that financial constraints have a positive influence on firm value. Livdan et al. (2009) find strong support for the findings of Whited and Wu (2006). However, in a recent paper, Li and Luo (2019) argue that the crucial driver of the relationship between financial constraints and stock returns is stock liquidity.

In summary, it can be concluded that there are conflicting findings on the impact of financial constraints on firm performance. However, a broad view of the findings suggests the following hypotheses for this study: 
$\boldsymbol{H}_{1}$ : Financial constraints have a significant impact on firm performance.

$\boldsymbol{H}_{2}$ : Measure choice, estimation methods, regional difference, control variable used, and the strength of results all have a significant moderating effect on the relationship between financial constraints and firm performance.

\subsection{Sampling Procedure for Meta-Analysis}

The analysis is divided into the following steps: (1) identify relevant studies with results that can be used as effect sizes; (2) categorise the papers according to the different measures of firm performance, and retain only the papers that analyse common measures of firm performance, such as, ROA, ROE, stock return, Tobin's Q, market to book, market value; and, similarly, measures of financial constraints such as, cash flow, size, the KZ, SA, WW, and ACW indexes, and external financing indexes; (3) calculate the effect sizes for the selected studies; (4) estimate the population mean effect size; (5) test the heterogeneity of the effect sizes; and (6) use meta-regressions to investigate potential sources of heterogeneity that can be identified from the selected studies.

\subsubsection{Identify Relevant Studies}

To identify the studies for the meta-analysis, an exhaustive search using keywords and terms such as: financial constraints, financial frictions, capital constraints, financial constraints and firm performance, financial constraints and 
ROA, financial constraints and firm value, financial constraints and Tobin's Q, financial constraints and stock return, and financial constraints and market to book; was conducted in order to identify relevant studies in Google Scholar, Science Direct, Emerald, JSTOR, EBSCO, and the Victoria University of Wellington Library. Also, the reference lists of identified studies were used to obtain other relevant studies. Among the identified studies those that did not report on empirical studies were excluded. The following criteria were applied for each study to be included in the sample of studies:

I. The paper is not an earlier version of another paper included in the sample.

II. The samples in the reported study are of publicly listed firms. Restricting the scope of papers to publicly listed firms should increase the comparability of the impact of financial constraints on financial performance measures used across different countries.

III. The study has firm performance as the dependent variable.

IV. The study reports the relevant regression results.

This process yielded a sample of 26 primary studies 'published' from 2001 to 2018 with 189 independent usable regressions. The studies cover 11 jurisdictions (Australia, China, France, Germany, India, Japan, Latin America, UK, USA, Vietnam, and cross-country) and span the data years 1963-2016. The studies produce more than one regression result, by using different measures of firm performance or financial constraints, alternative model specifications, different years, different regions, or different control variables. This study did not apply 
any exclusion criteria based on the apparent quality of the primary studies; however, journal quality as a study characteristic was included in analysing the sources of heterogeneity in the effect sizes.

It is important to note that, three types of missing data have a potential effect on the paper selection process: (1) missing significance level, (2) missing sample size, and (3) omitted model parameters (Wang and Shailer, 2015). In this study, all the papers selected report the significance level of the results and sample size.

\subsubsection{Calculate Effect Size}

To calculate effect sizes (ES) and other statistics, the present study employs the procedures and models in Rosenthal (1991) and Lipsey and Wilson (2001). Effect size indicates the degree of association between the key variables and, in principle, is measured by the product moment correlation coefficient (r), which indicates both direction and magnitude of relations, as well as being scale-free (Lipsey and Wilson, 2001). However, the correlation coefficient is usually not reported and, therefore, the reported t-value, or z-statistic, or p-value is used to estimate the effect size. ${ }^{9}$

\footnotetext{
${ }^{9}$ To estimate effect size from the p-value, use can be made of a web-based effect-size calculator developed by Professor David. B. Wilson. This web-based calculator is based on the book "Practical Meta-Analysis" by Lipsey and Wilson (2001). Website: https://www.campbellcollaboration.org/escalc/html/EffectSizeCalculator-R7.php
} 
Given the $t$ value, the effect size is given by

$$
E S_{r}=\sqrt{\frac{t^{2}}{\left(t^{2}+d f\right)}}
$$

where, $d f$ is the degrees of freedom. If the study does not report $t$ values but reports parameter estimates and standard errors, the $t$ value is first calculated as follows:

$$
t=b / s
$$

where, $b$ is the parameter estimate and $s$ is the standard error.

If the $z$ statistic is given, the effect size is obtained from:

$$
E S_{r}=\sqrt{\frac{Z^{2}}{N}}
$$

where, $n$ is the number of observations in the study sample.

The correlation coefficient has problematic statistical properties and, thus, the Fisher $\mathrm{Z}$ transformation is applied to all the estimated effect sizes (Lipsey and Wilson 2001). 


\subsubsection{Estimate the Weighted Mean Effect Size and Standard}

\section{Error}

The weighted mean effect size and standard error are then calculated based on the random effects model (Borenstein, Hedges, and Rothstein, 2007). This assumption is particularly appropriate where the studies analysed vary in terms of the period studied and the countries studied; in that case, there will not be a common effect size, rather, the different studies will vary in terms of underlying true effect size. The random effects model assumes that, beyond sampling error, there is excess heterogeneity from differences in the effect size estimates. The variance of the effect sizes in a random effects model is given by $v_{i}+\tau^{2}$, where $v_{i}$ is the within-study variance associated with sampling error and $\tau^{2}$ is the estimate of the between-study variance.

Estimation of the weighted mean effect size and standard error for the random effects model starts with estimation of $\tau^{2}$ from the values estimated for the weights, and the $Q$-statistic. The Q statistic provides a test for identifying excess variance (that is, fixed effects) in a sample of effect sizes. The formulas for estimation of the weights and $Q$-statistic and the subsequent steps to obtain the mean effect size and standard error are shown in Table 2.2, Panel A, and Table 2.2, Panel B. 
Table 2.2 Panel A: Description of formulas for the meta-analysis assuming fixed effect model

\begin{tabular}{|c|c|c|}
\hline Name of formula & Calculation & Description \\
\hline $\begin{array}{l}\text { Effect size using } \\
\text { correlation }\end{array}$ & $E S_{r}=r$ & ES represents effect size and $\mathrm{r}$ is the product-moment correlation coefficient. \\
\hline $\begin{array}{l}\text { Effect size using t- } \\
\text { value }\end{array}$ & $E S_{r}=\sqrt{\frac{t^{2}}{\left(t^{2}+d f\right)}}$ & $t$ is t-value and $d f$ is the degrees of freedom given by $n-1$ where $\mathrm{n}$ is the sample size. \\
\hline $\begin{array}{l}\text { Effect size using z- } \\
\text { statistic }\end{array}$ & $E S_{r}=\sqrt{\frac{Z^{2}}{N}}$ & $Z$ is $z$-statistic and $N$ is the total sample size. \\
\hline Fisher Z & $Z_{r}=0.5 \log _{e}\left[\frac{1+E S_{r}}{1-E S_{r}}\right]$ & $E S_{z_{r}}$ is the Fisher z-transformed effect size. \\
\hline Standard error & $S E_{z_{r}}=\frac{1}{\sqrt{n_{i}-3}}$ & $\begin{array}{l}S E_{z_{r}} \text { is standard error for each calculated effect size and } n_{i} \text { is the sample size for each } \\
\text { study. }\end{array}$ \\
\hline Inverse variance & $w_{i}=\frac{1}{S E_{z_{r}}^{2}}$ & $w_{i}$ is the weight given to the sample size of each study. \\
\hline $\begin{array}{l}\text { Weighted mean } \\
\text { effect size }\end{array}$ & $\overline{E S}=\frac{\sum\left(w_{i} E S_{i}\right)}{\sum w_{i}}$ & $\begin{array}{l}\overline{E S} \text { is the mean effect size calculated for all effect sizes in the meta-analysis. This is the } \\
\text { main statistic of interest to capture the aggregate effect of the test variable on the } \\
\text { dependent variable. }\end{array}$ \\
\hline $\begin{array}{l}\text { Standard error of } \\
\text { the mean }\end{array}$ & $S E_{\overline{E S}}=\frac{1}{\sqrt{\sum w_{i}}}$ & $\begin{array}{l}S E_{\overline{E S}} \text { this is the standard error of the mean computed as the square root of the sum of } \\
\text { the inverse variance weights }\end{array}$ \\
\hline
\end{tabular}

***Sources: Lipsey and Wilson, (2001) and Opare et al. (2019) 
Table 2.2 Panel B: Description of formulas for the meta-analysis assuming random effect model

\begin{tabular}{|c|c|c|}
\hline Name of formula & Calculation & Description \\
\hline Chi-square statistic & $Q=\Sigma w_{i}\left(E S_{i}-\overline{E S}\right)^{2}$ & $\begin{array}{l}\text { This is for the homogeneity test based on the Q statistic, which is distributed as a chi- } \\
\text { square with k-1 degrees of freedom where } \mathrm{k} \text { is the number of effect sizes in the study. }\end{array}$ \\
\hline Tau squared & $\tau^{2}=\frac{Q-d f}{\sum w_{i}-\frac{\sum w_{i}^{2}}{\sum w_{i}}}$ & $\begin{array}{l}\text { This is an estimate of the between-study variance. Q is the Q-statistic and df is the degrees } \\
\text { of freedom. }\end{array}$ \\
\hline Weight & $w_{i}^{*}=\frac{1}{v_{i}^{*}}$ & This is the weight assigned to each study where $v_{i}^{*}$ the total variance for each study is. \\
\hline Total variance & $v_{i}^{*}=v_{i}+\tau^{2}$ & $\begin{array}{l}\text { The total variance includes the within-study variance for study i plus the between-studies } \\
\text { variance, tau-squared. }\end{array}$ \\
\hline $\begin{array}{l}\text { Weighted mean } \\
\text { effect size }\end{array}$ & $\overline{E S}^{*}=\frac{\sum\left(w_{i}^{*} E S_{i}\right)}{\sum w_{i}^{*}}$ & $\overline{E S}^{*}$ is the mean effect size calculated assuming a random effect model. \\
\hline $\begin{array}{l}\text { Variance of mean } \\
\text { effect size }\end{array}$ & $v^{*}=\frac{1}{\sum w_{i}^{*}}$ & This is the reciprocal of the sum of the weights \\
\hline $\begin{array}{l}\text { Standard error of } \\
\text { mean effect size }\end{array}$ & $S E_{\overline{E S}}^{*}=\sqrt{v^{*}}$ & $\begin{array}{l}S E_{\overline{E S}} \text { is the standard error of mean effect size computed as the square root of the variance } \\
\text { of mean effect size. }\end{array}$ \\
\hline Lower limit & $\overline{E S}_{l}^{*}=\overline{E S}^{*}-1.96\left(S E_{\overline{E S}}\right)$ & $\begin{array}{l}\overline{E S}_{l}^{*} \text { is the lower limit given by subtracting the product of the critical } \mathrm{z} \text {-value and the } \\
\text { desired confidence interval from the mean effect size. }\end{array}$ \\
\hline Upper limit & $\overline{E S}_{u}^{*}=\overline{E S}^{*}+1.96\left(S E_{\overline{E S}^{*}}\right)$ & $\begin{array}{l}\overline{E S}_{u}^{*} \text { is the upper limit given by adding the product of the critical z-value and the desired } \\
\text { confidence interval to the mean effect size. }\end{array}$ \\
\hline Z-statistic & $Z^{*}=\frac{\left|\overline{E S}^{*}\right|}{S E_{\overline{E S}}}$ & $\begin{array}{l}\text { This tests the significance of the mean effect size. }\left|\overline{E S}^{*}\right| \text { is the absolute value of the mean } \\
\text { effect size and } S E_{\overline{E S}} \text { is the standard error of the mean effect size. }\end{array}$ \\
\hline Fail-safe number & $\begin{aligned} X=(k / 2.706)[ & k\left(Z^{*}\right)^{2} \\
& -2.706]\end{aligned}$ & $\begin{array}{l}\text { This calculates the number of studies that would make significant results become } \\
\text { insignificant. } k \text { is the number of studies and } Z^{*} \text { is the } z \text {-statistic. }\end{array}$ \\
\hline
\end{tabular}

***Sources: Lipsey and Wilson, (2001) and Opare et al. (2019) 
Having obtained an estimate of $\tau^{2}$, the weights for the random effects model are set equal to the reciprocal of $\left(v_{i}+\tau^{2}\right)$. The weighted mean effect size for a given measure is then computed as the sum of the products of each effect size and its weight, scaled by the sum of the weights. The mean standard error is computed as the square root of the sum of the weights. A confidence interval for the weighted mean effect size can then be calculated and, to test the significance of the mean effect size, the $z$-statistic is computed by dividing the mean effect size by the mean standard error.

The fail safe number to identify the 'File Drawer' problem has also been calculated. This is a test to check for publication bias, following Rosenthal (1991). In this study, the 'fail safe number' is the number of studies that would be required to overturn a conclusion drawn from a significant relationship between financial constraints and firm performance.

\subsubsection{Examine the Heterogeneity of the Effect Sizes}

To examine the sources of heterogeneity in the meta-analysis results a metaregression has been conducted, as an extension to the standard meta-analysis. The relevant information on the study characteristics likely to be sources of the heterogeneity: measure choices, control variables, estimation method, and strength of reported results; were coded for the regression. 


\subsubsection{Measure Choices}

Variation in the measure choices employed is likely to be a key determinant of variation in reported results on the impact for financial constraints on firm performance.

The study includes 8 common measures of firm performance, and the frequency of use of these measures was as follows: ROA (55), ROE (18), Stock Return (39), Tobin's Q (35), MTB (39), and OTHER_FP (3). Here, ROA, ROE, and sales growth are the accounting performance measures, whereas, Stock Return, Tobin's Q, Market to book, and Market value are the market performance measures. The different measures were analysed separately and, as in Wang and Shailer (2018), the study also tests for the potential moderating effect of accounting or market performance measures, by including a dummy variable equal to 1 if the regression uses a market performance measure, and 0 otherwise. Cash flow (21), EXT_FIN the KZ (41), SA (3), Size (72), WW (18), and ACW (16) were used as the measures of financial constraints in the regression (with frequency of use shown in brackets).

2.3.4.2 Control Variables: A range of control variables were used in the regressions reported in the primary studies. Based on their similarities, the common firm-specific control variables were identified: size, leverage, growth, firm and year fixed effect, industry fixed effect, tangibility, research and development expenses, liquidity, market-based performance, country effect and corporate governance. 
2.3.4.3 Estimation Methods: The studies use a variety of statistical models, such as: firm fixed effects, year fixed effects, industry fixed effects, GMM, OLS, pooled OLS, clustered OLS, random effect cross-sectional regression, probit model, advanced panel regression, one-way sort, and neutralized sort.

2.3.4.4 Regional Difference: The studies focus on a particular region, or conduct a cross-country analysis. Different regional areas may have a significant impact on the relationship between financial constraints and firm performance owing to the differences in investors' behaviour or country laws. Therefore, the studies were divided into the different countries and were analysed separately for the impact of region on the relationship.

2.3.4.5 The Strength of Results: There are several additional factors that may affect the relationship between firm performance and financial constraints. These factors are indicators of the strength of the regression results reported in the studies included for the meta-analysis. The factors listed below were identified as other potential sources of heterogeneity:

2.3.4.5.1 Publication Bias: Publication bias is a major concern in meta-analysis literature. Some authors argue that studies that report statistically significant results, or findings that fit with the particular interest of the editors and reviewers, are more likely to be published than studies with non-significant 
results (Rosenthal, 1991; Duval and Tweedie, 2000; Scargle, 2000; Pomeroy and Thornton, 2008; and Wang and Shailer, 2015; Wang and Shailer, 2018). Some Meta studies exclude unpublished papers, because such paper lack a final review process that might have changed the results (Habib, 2012; Hay, Knechel, and Wong, 2006). To mitigate this publication bias, both published and unpublished papers were included in the study, as publication status may have a significant impact on the effect size estimates. The sample of 26 papers in this study includes two studies (Stikkelman, 2010; and Le, 2016) that had not been published in a journal, and one paper that had no journal ranking (Zhao, 2016).

2.3.4.5.2 Journal Quality: A dummy variable was included to control for the relative quality of the primary studies as indicated by journal ranking. Journal ranking is crucial, as it is likely to be a strong indicator of both the quality and the reliability of the effect size results. For coding, ABDC ranking was used, as issued by the Australian Business Deans Council. The ranking categories are; $\mathrm{A}^{*}, \mathrm{~A}, \mathrm{~B}$, and $\mathrm{C}$, where the highest quality is $\mathrm{A}^{*}$. Based on this ranking, the study has 135 effect sizes from 21 studies published in $\mathrm{A}^{*}$ or A ranked journals, and 54 effect sizes from 5 studies, either published in lower ranked journals or not published.

2.3.4.5.3 Year of Publication: In the regression, the year of publication was included to test whether the year of publication has any relationship with the reported results. It is more likely for studies on financial constraints to be 
published in later years, as more data has become available, and more researchers have developed an interest in this area of research.

2.3.4.5.4 Sample Size: The sample size in the studies ranges from 365 to 65,681 firm-year observations. The sample size is a significant part of meta-analysis as it gives weight to the effect size. The larger the sample size, the more representative the result would be expected to be. The studies that involve crosscountry analysis, or focus on US firms, have a larger sample size than do the other studies.

2.3.4.5.5 The Number of Years Covered: The sample period in the studies ranges from 2 to 44 years with an average of around 16 years. As with sample size, studies that cover longer periods would tend to be more representative.

\subsection{Meta-Regression Model}

The meta-regression model for examining sources of heterogeneity in the effect sizes, and testing the second Hypothesis $\left(H_{2}\right)$, is given below:

$$
\begin{gathered}
Z_{r}=\beta_{0}+\Sigma \beta_{1} \mathrm{FP}_{\mathrm{M}}+\Sigma \beta_{2} \mathrm{FC}_{\mathrm{M}}+\Sigma \beta_{3} \mathrm{CV}+\Sigma \beta_{4} \mathrm{SM}+\Sigma \beta_{5} R D+\Sigma \beta_{6} S R+ \\
\mu, \mu \sim N\left(0, v_{\iota}+\tau^{2}\right) \ldots \ldots(1)
\end{gathered}
$$

where, $Z_{r}$ is the Fisher transformed effect size for financial constraints on firm

performance. $F P_{M}$ is a vector of dummy variables for different measures of firm 
performance; $F C_{M}$ is a vector of dummy variables for different measures of financial constraints, $C V$ is a vector of dummy variables for the selected control variables (size, leverage, growth, tangibility, liquidity, research and development expenses, and cash flow); $S M$ is a vector of dummy variables representing the estimation methods (OLS, pooled OLS, clustered OLS, crosssectional regression, Probit model, GMM, advance panel regression, fixed effects, random effect, one way sort, and neutralized sort); RD is a vector of dummy variables representing the regional difference (Australia, Cross_Country, Europe, North_America, and Asia); SR is a vector of dummy variables which indicate strength of results ( publication status, journal quality, year of publication, sample size, and number of years covered). The variables are defined in Table 2.3. The $\beta$ are vectors of coefficients matching the vectors of variables.

To estimate the random-effects meta-regression model (REMR), the KnappHartung approach, which adjusts the standard error of the parameters, was used, to derive an unbiased estimator of the variance. For the robustness test, the REMR model was estimated by omitting variables with a few effect sizes. 
Table 2.3: Variable definitions

\begin{tabular}{|c|c|}
\hline Variable & Description \\
\hline \multicolumn{2}{|l|}{ Dependent variable } \\
\hline Fisher_Z & Fisher Z-transformed effect size. \\
\hline \multicolumn{2}{|l|}{ Independent variables } \\
\hline $\begin{array}{l}\text { Firm performance } \\
\text { measure }(F P) \text { : }\end{array}$ & Categorical variable based on different firm performance proxies. \\
\hline ROA & Dummy is 1 if the effect size estimate is based on ROA as a measure of firm performance \\
\hline ROE & Dummy is 1 if the effect size estimate is based on ROE as a measure of firm performance \\
\hline SR & $\begin{array}{l}\text { Dummy is } 1 \text { if the effect size estimate is based on Stock Return as a measure of firm } \\
\text { performance }\end{array}$ \\
\hline TOBINS_Q & $\begin{array}{l}\text { Dummy is } 1 \text { if the effect size estimate is based on Tobin's Q as a measure of firm } \\
\text { performance }\end{array}$ \\
\hline MTB & $\begin{array}{l}\text { Dummy is } 1 \text { if the effect size estimate is based on Market to Book as a measure of firm } \\
\text { performance }\end{array}$ \\
\hline OTHER_FP & $\begin{array}{l}\text { Dummy is } 1 \text { if the effect size estimate is based on Market Value or sales growth as a } \\
\text { measure of firm performance }\end{array}$ \\
\hline MRK_MEASURE & $\begin{array}{l}\text { Dummy is } 1 \text { if the effect size estimate is based on Market-based performance (Tobin's Q, } \\
\text { Stock Return, MTB, MV) }\end{array}$ \\
\hline $\begin{array}{l}\text { Financial constraints } \\
\text { measurement }(F C) \text { : }\end{array}$ & Categorical variable based on different financial constraint measures. \\
\hline $\mathrm{CF}$ & $\begin{array}{l}\text { Dummy is } 1 \text { if the effect size estimate is based on all cash flows (operating, financing and } \\
\text { investing) as a measure of financial constraints. }\end{array}$ \\
\hline EXT_FIN & $\begin{array}{l}\text { Dummy is } 1 \text { if the effect size estimate is based on other external finance indexes (External } \\
\text { finance index and ZFC index) as a measure of financial constraints }\end{array}$ \\
\hline
\end{tabular}




\begin{tabular}{|c|c|}
\hline KZ & $\begin{array}{l}\text { Dummy is } 1 \text { if the effect size estimate is based on } \mathrm{KZ} \text { index as a measure of financial } \\
\text { constraints }\end{array}$ \\
\hline SA & $\begin{array}{l}\text { Dummy is } 1 \text { if the effect size estimate is based on SA index as a measure of financial } \\
\text { constraints }\end{array}$ \\
\hline SIZE & $\begin{array}{l}\text { Dummy is } 1 \text { if the effect size estimate is based on firm size as a measure of financial } \\
\text { constraints }\end{array}$ \\
\hline WW & $\begin{array}{l}\text { Dummy is } 1 \text { if the effect size estimate is based on WW index as a measure of financial } \\
\text { constraints }\end{array}$ \\
\hline $\mathrm{ACW}$ & $\begin{array}{l}\text { Dummy is } 1 \text { if the effect size estimate is based on ACW index as a measure of financial } \\
\text { constraints }\end{array}$ \\
\hline E_MEASURE & $\begin{array}{l}\text { Dummy is } 1 \text { if the effect size estimate consider external financial constraints in the index } \\
\text { (SA, KZ, WW, External finance indexes, ACW) }\end{array}$ \\
\hline Estimation method: & Categorical variable based on different statistical model \\
\hline FE & Dummy is 1 if the primary study regression model uses firm fixed effects \\
\hline GMM & Dummy is 1 if the primary study regression model uses GMM method \\
\hline OLS & Dummy is 1 if the primary study regression model uses OLS method \\
\hline OTHER_EM & $\begin{array}{l}\text { Dummy is } 1 \text { if the primary study effect size is collected from correlation coefficient, } \mathrm{p}- \\
\text { value, probit model, one-way sort method, neutralized method or advance panel regression. }\end{array}$ \\
\hline $\mathrm{RE}$ & Dummy is 1 if the primary study regression model uses random effect model \\
\hline CROSS_REG & Dummy is 1 if the primary study regression model uses cross-sectional regression model \\
\hline Regional difference: & Categorical variable based on difference in country setting. \\
\hline AUSTRALIA & Dummy is 1 if the primary study's sample size is from Australia \\
\hline CROSS_COUNTRY & Dummy is 1 if the primary study's sample size is cross-country \\
\hline EUROPE & Dummy is 1 if the primary study's sample size is from Europe \\
\hline NORTH_AMERICA & Dummy is 1 if the primary study's sample size is from the USA and Canada \\
\hline ASIA & Dummy is 1 if the primary study's sample size is from Asia \\
\hline
\end{tabular}




\begin{tabular}{|c|c|}
\hline Control Variables: & \\
\hline C_SIZE & Dummy is 1 if the primary study includes a control variable for size of a firm \\
\hline LEV & Dummy is 1 if the primary study includes a control variable for leverage of a firm \\
\hline GROWTH & Dummy is 1 if the primary study includes a control variable for growth of a firm \\
\hline FIRM_FE & Dummy is 1 if the primary study includes a control variable for firm fixed effect \\
\hline YEAR_FE & Dummy is 1 if the primary study includes a control variable for year fixed effect \\
\hline INDUSTRY_FE & Dummy is 1 if the primary study includes a control variable for industry fixed effect \\
\hline TANGIBILITY & Dummy is 1 if the primary study includes a control variable for tangibility of a firm \\
\hline $\mathrm{RD}$ & $\begin{array}{l}\text { Dummy is } 1 \text { if the primary study includes a control variable for Research and development } \\
\text { expense of a firm }\end{array}$ \\
\hline LIQUIDITY & $\begin{array}{l}\text { Dummy is } 1 \text { if the primary study includes a control variable for cashflow and liquidity of a } \\
\text { firm }\end{array}$ \\
\hline M_PERFORMANCE & Dummy is 1 if the primary study regression controls for market to book or Tobin's Q. \\
\hline COUNTRY_EFFECT & Dummy is 1 if the primary study regression controls for country-based economic effect \\
\hline C_GOVERNANCE & $\begin{array}{l}\text { Dummy is } 1 \text { if the primary study regression controls for corporate governance elements } \\
\text { (ex. Stakeholder engagement) }\end{array}$ \\
\hline \multicolumn{2}{|l|}{ Strength of results: } \\
\hline S_SIZE & Log of sample size of the effect size estimate \\
\hline J_QUALITY & $\begin{array}{l}\text { Dummy is } 1 \text { if the primary study is published in a high-quality journal ( } \mathrm{A}^{*} \text { and A ranked } \\
\text { journal) }\end{array}$ \\
\hline PUB_YEAR & The year a paper published or written for unpublished paper \\
\hline PUB_STATUS & Dummy is 1 if the study is published in a journal \\
\hline Y_COVERED & Number of years in the sample window \\
\hline
\end{tabular}




\subsection{Results and Analysis}

In this section the summary statistics, the regression results and the robustness test results are discussed in detail.

\subsubsection{Summary of the Studies}

Table 2.4, Panels A and B summarise the sample of studies that were included in the meta-analysis.

Table 2.4, Panel A, provides a summary of all papers collected and their sources. It also shows that fourteen papers focused on the US, only one on Latin America, one on Australia, four on Asia, two on Europe, and four on multiple countries. Most of the papers were relatively recent.

Table 2.4, Panel A, also shows the journal quality of individual papers and the number of effect sizes collected from each of the papers. All the US based papers were publised in highly ranked journals (12 papers in $A^{*}$ ranked and 2 papers in A ranked journals). The result shows that the highest number of effect sizes came from Jin et al. (2018) and Nguyen et al. (2016) (35 and 32 repectively). 
Table 2.4 Panel A: Summary of studies included in the meta-analysis

\begin{tabular}{|c|c|c|c|c|c|}
\hline Author and year & Country & Sample period & Sample size (N) & Journal Ranking & No. of effect sizes \\
\hline Almeida \& Campello (2003) & USA & $1971-2000$ & 17880 & $\mathrm{~A}^{*}$ & 8 \\
\hline Alvarez et al. (2016) & Latin America & $1999-2013$ & 7239 & A & 1 \\
\hline Baker et al. (2003) & USA & 1980-1999 & 52101 & $A^{*}$ & 1 \\
\hline Billett \& Mauer (2003) & USA & $1990-1998$ & 4204 & $A^{*}$ & 6 \\
\hline Bodnaruk et al. (2015) & USA & $1997-2011$ & 51533 & $A^{*}$ & 3 \\
\hline Borisova et al. (2013) & USA & $1980-2009$ & 36923 & $A^{*}$ & 1 \\
\hline Caballero et al. (2014) & UK & 2001-2007 & 1606 & A & 6 \\
\hline Campello \& Chen (2010) & USA & $1963-2006$ & 65681 & $\mathrm{~A}^{*}$ & 8 \\
\hline Chan et al. (2010) & Australia & $1975-2004$ & 4470 & A & 3 \\
\hline Chen \& Wang (2012) & USA & $1968-1995$ & 4710 & $A^{*}$ & 9 \\
\hline Cleary (2006) & $\mathrm{CC}$ & $1987-1997$ & 365 & $A^{*}$ & 7 \\
\hline Haider et al. (2018) & $\mathrm{CC}$ & $1999-2000$ & 8232 & A & 1 \\
\hline Hennessy et al. (2007) & USA & $1968-2003$ & 1723 & $\mathrm{~A}^{*}$ & 4 \\
\hline Jin et al. (2018) & $\mathrm{CC}$ & $2000-2014$ & Varies & A & 35 \\
\hline Khatami et al. (2015) & USA & $1985-2013$ & Varies & A & 3 \\
\hline Lamont et al. (2001) & USA & 1968-1997 & 1056 & $A^{*}$ & 9 \\
\hline Le (2016) & USA & 1982-2009 & 13536 & Unpublished & 1 \\
\hline Li (2011) & USA & $1975-2007$ & Varies & $\mathrm{A}^{*}$ & 2 \\
\hline Martinez - Sola et al. (2013) & USA & $2001-2007$ & 3055 & A & 6 \\
\hline Maso et al. (2018) & $\mathrm{CC}$ & $2002-2014$ & Varies & A & 12 \\
\hline Nguyen et al. (2016) & Vietnam & $2008-2013$ & 1638 & $\mathrm{~B}$ & 32 \\
\hline Sasidharan et al. (2015) & India & $1991-2011$ & 5603 & B & 2 \\
\hline Stikkelman (2010) & France & 1999-2008 & Varies & Unpublished & 18 \\
\hline Whited \& Wu (2006) & USA & $1975-2001$ & 1390 & $\mathrm{~A}^{*}$ & 6 \\
\hline Zhao \& Xiao (2018) & China & $2010-2016$ & 11865 & A & 3 \\
\hline Zhao (2016) & China & 2002-2009 & 6515 & Not Ranked & 2 \\
\hline
\end{tabular}


Table 2.4, Panel B, shows the number of effect sizes collected from the different journals and their rankings. It demonstrates that the highest number of effect sizes, 34, came from the journal, 'International Review of Economics and Finance' (ABDC ranking A). The second highest number of effect sizes, 31, came from the journals, 'The Review of Financial Studies' (ABDC ranking A*) and 'Australian Economic Papers' (ABDC ranking B).

Table 2.4 Panel B: Journal quality rankings included in meta-analysis

\begin{tabular}{lcc}
\hline Journal & $\begin{array}{c}\text { No. of } \\
\text { effect } \\
\text { sizes }\end{array}$ & $\begin{array}{c}\text { ABDC } \\
\text { Ranking }\end{array}$ \\
\hline Emerging Markets Review & 1 & A \\
Applied Economics & 6 & A \\
Australian Economic Paper & 31 & B \\
International Review of Economics and Finance & 34 & A \\
International Review of Financial Analysis & 3 & A \\
Journal of Banking \& Finance & 8 & A* \\
Journal of Business Research & 6 & A \\
Journal of Environmental Management & 12 & A \\
Journal of Financial and Quantitative Analysis & 3 & A* \\
Journal of Financial Economics & 14 & A* \\
Journal of International Financial Markets, Institutions \& Money & 1 & A \\
Journal of Money, Credit and Banking & 8 & A* \\
Modern Economy & 2 & n/a \\
Pacific-Basin Finance Journal & 3 & A \\
The Journal of Finance & 4 & A* \\
The Quarterly Journal of Economics & 1 & A* \\
The Quarterly Review of Economics and Finance & 2 & B \\
The Review of Financial Studies & 31 & A* \\
Unpublished papers & 19 & n/a \\
\hline Total & 189 & \\
\hline
\end{tabular}




\subsubsection{Distribution of Effect Size Results by Primary Studies}

Table 2.5, Panel A, reports the distribution of effect size results for each of the primary studies, and summarises the effect size results for the relationship between financial constraints and firm performance. Here, the studies are listed in alphabetical order of the lead author for each dimension. Khatami, Marchica, and Mura (2015) and Baker at al. (2003) reported large mean (within study) effect sizes (mean $E S=0.163$ and mean $E S=0.153$ respectively). On the other hand, Campello and Chen (2010) reported the smallest mean effect size (mean $E S=-0.008)$. Overall, analysis of Table 2.5 Panel A shows that there are 7 negative effect sizes and 19 positive effect sizes with an overall mean effect size 0.037 and $p$-value 0.056 .

\subsubsection{Distribution of Effect Sizes by Firm Performance Measure}

Table 2.5, Panel B, reports effect sizes by firm performance measure. ROA produces the highest mean effect size of 0.050 and Market to Book produces the smallest mean effect size of 0.0265 .

\subsubsection{Distribution of Effect Size Results by Financial Constraints Measure}

Table 2.5, Panel C, provides effect size results by financial constraints measure. External Finance (Ext_Fin) produces the highest mean effect size of 0.110, whereas, the WW Index shows a small negative mean effect size. 


\subsubsection{Distribution of Effect Size Results by Statistical Model}

Table 2.5, panel D, shows that RE produces the highest mean effect size: 0.083 , whereas, OTHER_EM reports the lowest mean effect size: -0.0080 .

\subsubsection{Distribution of Effect Size Results by Different Regional Area}

Table 2.5, Panel E, reports a summary of effect sizes by different regional areas. Asia has the highest mean effect size: 0.054 , and Europe shows the smallest mean effect size: 0.009 .

\subsubsection{Count of Positive and Negative Effect Sizes by Subsections}

Table 5, Panel F, shows that, of the 189 effect sizes across the individual studies, 126 are positive while 63 are negative. Market-to-book (31) as a measure of firm performance, Size (45) as a measure of financial constraints, OLS (49) as an estimation method, and North America (47) as a regional area have the highest number of positive effect sizes in each subsection. ROA (26) as a measure of firm performance, Size (27) as a measure of financial constraints, OLS (32) as an estimation method, and Cross country (29) as a regional area, have the highest number of negative effect sizes in each subsection.

\subsubsection{Overall Summary of Effect Size Results (Using Random Effects)}

Table 2.5, Panel G, provides a summary of the effect size results (using Random effects), and also the results of the publication bias test. The overall mean effect size for the relationship between financial constraints and firm performance is 0.0034 , and it is significant at the $1 \%$ level $(Z$-statistic $=4.19)$. In consistent with 
$\mathrm{H}_{1}$, the results thus show that, overall, financial constraints have a positive and significant impact on firm performance. Therefore, the results support $\mathrm{H}_{1}$. However, there is clearly variation among the effect size results. The sources of this variation are investigated in the meta regression analysis.

Table 2.5 Panel A: Within study mean effect size by primary studies

\begin{tabular}{lc}
\hline & Mean \\
Authors & Effect \\
Size \\
\hline Almeida \& Campello (2007) & 0.0375 \\
Alvarez et al. (2016) & 0.0490 \\
Baker et al. (2003) & 0.1527 \\
Billett \& Mauer (2003) & 0.0161 \\
Bodnaruk et al. (2015) & 0.0058 \\
Borisova et al. (2013) & -0.0173 \\
Caballero et al. (2014) & -0.0171 \\
Campello \& Chen (2010) & -0.0078 \\
Chan et al. (2010) & 0.0359 \\
Chen \& Wang (2012) & 0.0549 \\
Cleary (2006) & -0.0517 \\
Haider et al. (2018) & -0.0453 \\
Hennessy et al. (2007) & -0.0122 \\
Jin et al. (2018) & 0.0622 \\
Khatami et al. (2015) & 0.1634 \\
Lamont et al. (2001) & 0.0940 \\
Le (2016) & 0.0356 \\
Li (2011) & 0.0239 \\
Martinez-Sola et al. (2013) & 0.0135 \\
Maso et al. (2018) & 0.0059 \\
Nguyen et al. (2016) & 0.0640 \\
Sasidharan et al. (2015) & 0.0044 \\
Stikkelman (2010) & 0.0351 \\
Whited \& Wu (2006) & -0.0500 \\
Zhao \& Xiao (2018) & 0.0445 \\
Zhao (2016) & 0.0703 \\
\hline & \\
\hline &
\end{tabular}


Table 2.5 Panels B to E: Summary of Effect size results by measurement of firm performance, financial constraints, statistical models, and regional difference

\begin{tabular}{lclclccc}
\hline \multicolumn{1}{c}{ Panel B } & \multicolumn{2}{c}{ Panel C } & \multicolumn{2}{c}{ Panel D } & Panel E \\
\hline $\begin{array}{l}\text { Measurement } \\
\text { of FP }\end{array}$ & $\begin{array}{c}\text { Mean } \\
\text { Effect Size }\end{array}$ & $\begin{array}{l}\text { Measurement } \\
\text { of FC }\end{array}$ & $\begin{array}{c}\text { Mean } \\
\text { Effect Size }\end{array}$ & $\begin{array}{l}\text { Estimation } \\
\text { methods }\end{array}$ & $\begin{array}{c}\text { Mean } \\
\text { Effect Size }\end{array}$ & $\begin{array}{l}\text { Regional difference } \\
\text { Effect Size }\end{array}$ \\
\hline ROA & 0.0503 & CF & 0.0469 & FE & 0.0461 & AUSTRALIA \\
ROE & 0.0322 & EXT_FIN & 0.1102 & GMM & 0.0752 & CROSS_COUNTRY & 0.0459 \\
SR & 0.0402 & KZ & 0.0565 & OLS & 0.0441 & EUROPE \\
TOBINS_Q & 0.0271 & SA & 0.0781 & OTHER_EM & -0.0080 & NORTH_AMERICA \\
MTB & 0.0265 & SIZE & 0.0195 & RE & 0.0828 & ASIA & 0.0313 \\
OTHER_FP & 0.0317 & WW & -0.0002 & CROSS_REG & 0.0061 & 0.0544 \\
& & ACW & 0.0010 & & & & \\
\hline
\end{tabular}

Table 2.5 Panel F: Count of positive and negative effect sizes (ES) by subsections

\begin{tabular}{|c|c|c|c|c|c|c|c|c|c|c|c|c|c|c|c|}
\hline Classification & $\begin{array}{c}+ \\
\text { ES }\end{array}$ & $\begin{array}{c}- \\
\text { ES }\end{array}$ & Total & Classification & $\begin{array}{c}+ \\
\mathrm{ES}\end{array}$ & $\begin{array}{c}- \\
\text { ES }\end{array}$ & Total & Classification & $\begin{array}{c}+ \\
\mathrm{ES}\end{array}$ & $\begin{array}{c}- \\
\text { ES }\end{array}$ & Total & Classification & $\begin{array}{c}+ \\
\mathrm{ES}\end{array}$ & $\begin{array}{c}- \\
\text { ES }\end{array}$ & Total \\
\hline $\begin{array}{l}\text { Measurement } \\
\text { of FP }\end{array}$ & & & & $\begin{array}{l}\text { Measurement } \\
\text { of FC }\end{array}$ & & & & $\begin{array}{l}\text { Estimation } \\
\text { methods }\end{array}$ & & & & Regional difference & & & \\
\hline ROA & 29 & 26 & 55 & $\mathrm{CF}$ & 19 & 2 & 21 & FE & 25 & 7 & 32 & AUSTRALIA & 1 & 3 & 4 \\
\hline ROE & 6 & 12 & 18 & EXT_FIN & 1 & 17 & 18 & GMM & 12 & 4 & 16 & CROSS_COUNTRY & 19 & 29 & 48 \\
\hline SR & 30 & 9 & 39 & $\mathrm{KZ}$ & 33 & 8 & 41 & OLS & 49 & 32 & 81 & EUROPE & 22 & 5 & 27 \\
\hline TOBINS Q & 27 & 8 & 35 & SA & 2 & 1 & 3 & OTHER_EM & 20 & 10 & 30 & NORTH AMERICA & 47 & 22 & 69 \\
\hline MTB & 31 & 8 & 39 & SIZE & 45 & 27 & 72 & $\mathrm{RE}$ & 9 & 1 & 10 & ASIA & 37 & 4 & 41 \\
\hline \multirow[t]{2}{*}{ OTHER_FP } & 3 & 0 & 3 & WW & 16 & 2 & 18 & CROSS_REG & 11 & 9 & 20 & & & & \\
\hline & & & & ACW & 10 & 6 & 16 & & & & & & & & \\
\hline
\end{tabular}


Table 2.5 Panel G: Summary of effect size results (using random effect calculation) and publication biased test

\begin{tabular}{lc}
\hline Particulars & Outcomes \\
\hline Mean ES & 0.0034 \\
SE (Mean ES) & 0.0008 \\
Z* stat & 4.1895 \\
p-value & 0.000028 \\
Fail-Safe number & 4358.77 \\
Tolerance Level & 140 \\
\hline
\end{tabular}

Table 2.5, Panel G, also reports the result of the test for publication bias. The fail safe number is 4359 , whereas, the tolerance level is only $140^{10}$. As the fail safe number is much greater than the reasonable tolerance level, publication bias can be eliminated.

\subsubsection{Meta-Regression Results}

The various sources of heterogeneity were examined using the random effects meta regression model, Equation (1) above. The set of dummy variables representing the choice of measures used is such that each observation scores on exactly one of the dummies and, therefore, estimation of the model runs into the problem of perfect multicollinearity. The usual approach to estimation is then to exclude one of the dummy variables, with the result that the coefficients obtained on the included dummy variables show the impact of those variables relative to the impact of the excluded variable. However, the results differ depending on which variable is excluded and, therefore, they are difficult to interpret. Hence,

${ }^{10}$ The tolerance level is calculated as $\mathrm{Y}=\left(5^{*} K\right)+10$, where $K$ is the number of studies. 
the approach introduced in Suits (1984) has been applied, which provides coefficients for all the dummy variables, and these indicate the effect of each variable relative to the mean effect of the set of variables. This technique is applied in the case of the measures of firm performance and financial constraints, estimation methods, and regional differences. The meta-regression results are reported in Tables 2.6 and 2.7 .

In Table 2.6, all the measures were used separately to analyse the impact of the choice of each measure on effect size. The adjusted R-squared reported in Table 6 shows that the variables explain $38.15 \%$ of the heterogeneity. The I-Square $(98.33 \%)$ is an indicator of the variability that is not attributable to sampling error (Ringquist, 2013, p.123)

\subsubsection{Choice of Measures}

Among the choice of measures of firm performance, ROA (coefficient $=-0.076$; $t$ value $=-3.243 ; p=0.001$ ), and $\operatorname{ROE}($ coefficient $=-0.067 ; t$ value $=-2.370 ; p=$ 0.019) both have a significant and negative impact on effect size relative to the mean impact on effect size. The impact of ROA is significant at the $1 \%$ level and ROE at the 5\% level. Stock return (SR) (coefficient $=0.087 ; t$ value=2.184; $p=0.030)$ and the set of other measures of firm performance (OTHER_FP) (coefficient $=0.114 ;$ value $=1.807 ; p=0.072)$ both have a positive impact relative to the mean impact on the effect size. The impact of stock return is significant at the 5\% level and the set of other measures at the $10 \%$ level. 
Among the choice of measures of financial constraints, external finance $($ EXT_FIN) $($ coefficient $=-0.069 ; t$ value $=-2.099 ; p=0.037)$ and Size $($ coefficient $=-0.049 ; t$ value $=-2.067 ; p=0.040)$ both have a significant and negative impact at the $5 \%$ level. On the other hand, the WW index (coefficient $=0.099 ; t$ value $=3.797 ; p=0.000)$ has a significant and positive impact at the $1 \%$ level relative to the mean impact on effect size. Therefore, in respect of the choice of measures, the results support $\mathrm{H}_{2}$.

\subsubsection{Estimation Methods}

None of the estimation methods have a significant impact relative to the mean impact of estimation methods on effect size. Therefore, in respect of the estimation methods, $\mathrm{H}_{2}$ is rejected.

\subsubsection{Regional Difference}

Regional differences could have a_significant impact on the variation in the findings, because of differing legal and institutional settings. The results show that cross-country $($ coefficient $=0.100 ; t$ value $=2.207 ; p=0.029)$ and Europe (coefficient $=0.096 ; t$ value $=2.540 ; p=0.012$ ) both have significant and

positive impacts relative to the mean at the $5 \%$ level. On the other hand, Asia has a significant but negative impact at the $1 \%$ level. Given the large number of studies that focus on the US it might seem surprising that they do not yield a 
significant coefficient. However, the finding that the coefficient is not significantly different from the mean impact, might have been expected. Therefore, in respect of the regional difference, the results support $\mathrm{H}_{2}$.

\subsubsection{Control Variables}

None of the control variables have an impact that is significantly different from the mean impact. Therefore, in respect of the control variables, $\mathrm{H}_{2}$ is rejected.

\subsubsection{Strength of Results}

Journal quality $($ coefficient $=-0.309 ; t$ value $=-4.83 ; p=0.000)$ and publication status $($ coefficient $=0.398 ; t$ value $=3.73 ; p=0.000)$ both have a significant impact relative to the mean impact. Journal quality has a negative impact and publication status a positive impact, both at the $1 \%$ level. Therefore, in respect of the strength of results, the results support $\mathrm{H}_{2}$. 
Table 2.6: Random effect Meta-regression (With Knapp-Hartung modification)

\begin{tabular}{|c|c|c|}
\hline Fisher_Z & Coefficient & $\mathrm{t}$-value \\
\hline \multicolumn{3}{|l|}{ Measurement of FP } \\
\hline ROA & $-0.076^{* * *}$ & 3.243 \\
\hline ROE & $-0.067^{* *}$ & 2.370 \\
\hline SR & $0.087^{* *}$ & 2.184 \\
\hline TOBINS_Q & -0.029 & -1.196 \\
\hline МТВ & -0.030 & -1.281 \\
\hline OTHER_FP & $0.114^{*}$ & 1.807 \\
\hline \multicolumn{3}{|l|}{ Measurement of FC } \\
\hline $\mathrm{CF}$ & 0.040 & 1.396 \\
\hline EXT_FIN & $-0.069^{* *}$ & -2.099 \\
\hline $\mathrm{KZ}^{-}$ & 0.034 & 1.439 \\
\hline SA & -0.054 & -1.112 \\
\hline SIZE & $-0.049^{* *}$ & -2.067 \\
\hline WW & $0.099^{* * * *}$ & 3.797 \\
\hline ACW & -0.001 & -0.021 \\
\hline \multicolumn{3}{|l|}{ Estimation methods } \\
\hline FE & 0.036 & 1.396 \\
\hline GMM & 0.039 & 1.465 \\
\hline OLS & 0.018 & 0.995 \\
\hline OTHER_EM & -0.038 & -1.538 \\
\hline RE & 0.014 & 0.489 \\
\hline CROSS_REG & -0.068 & -1.454 \\
\hline \multicolumn{3}{|l|}{ Regional difference } \\
\hline AUSTRALIA & -0.036 & -0.771 \\
\hline CROSS_COUNTRY & $0.100^{* *}$ & 2.207 \\
\hline EUROPE & $0.096^{* *}$ & 2.540 \\
\hline NORTH_AMERICA & -0.034 & -1.320 \\
\hline ASIA & $-0.126^{* * *}$ & -3.491 \\
\hline \multicolumn{3}{|l|}{ Control } \\
\hline C_SIZE & -0.046 & -1.310 \\
\hline LEV & -0.048 & -1.000 \\
\hline GROWTH & 0.000 & 0.000 \\
\hline FIRM_FE & 0.015 & 0.390 \\
\hline YEAR_FE & 0.012 & 0.320 \\
\hline INDUSTRY_FE & 0.027 & 0.700 \\
\hline TANGIBILIT̄Y & 0.047 & 1.140 \\
\hline $\mathrm{RD}$ & 0.026 & 0.510 \\
\hline LIQUIDITY & -0.015 & -0.420 \\
\hline M_PERFORMANCE & 0.007 & 0.150 \\
\hline COUNTRY_EFFECT & -0.014 & -0.430 \\
\hline C_GOVERNANCE & -0.085 & -1.070 \\
\hline \multicolumn{3}{|l|}{ Strength of result } \\
\hline S_SIZE & -0.014 & -0.650 \\
\hline J_QUALITY & $-0.309^{* * * *}$ & -4.830 \\
\hline PUB_YEAR & -0.002 & -0.680 \\
\hline PUB_STATUS & $0.398^{* * *}$ & 3.730 \\
\hline Y_CŌVERED & -0.002 & -0.980 \\
\hline CONNSTANT & 4.844 & 0.680 \\
\hline Number of ES & \multirow{2}{*}{\multicolumn{2}{|c|}{189}} \\
\hline tau-squared $\left(\tau^{2}\right)$ & & \\
\hline I-squared & \multirow{2}{*}{\multicolumn{2}{|c|}{$98.33 \%$}} \\
\hline Adj $R^{2}$ & & \\
\hline
\end{tabular}

Note: The Table reports regression analysis of sources of heterogeneity in the effect size for financial constraints on firm performance. The dependent variable is Fisher_Z. The variables are defined in Table 2.3. ${ }^{* * *} p<0.01$,

$* * \mathrm{p}<0.05, * \mathrm{p}<0.10$. 


\subsubsection{Robustness Test}

\subsubsection{Grouping the Measure Choice}

Table 2.7, shows the result of simplifying the coding of the set of measures for firm performance and for financial constraints. Following Wang and Shailer (2018), A dummy variable was included to divide the set of measures for performance into accounting-based and market-based performance and, similarly, the set of measures for constraints into external-based and internalbased financial constraints. The results are discussed below.

The R-squared reported in Table 2.7 shows that the variables explain $30.75 \%$ of the heterogeneity.

\subsubsection{Choice of Measures}

Among the choice of measures of firm performance, the set of market-based measures $($ coefficient $=-0.051, t$ value $=-1.71 p=0.089)$ has a negative impact on effect size relative to the accounting-based measures, but only at the $10 \%$ level of significance.

Among the choice of measures of financial constraints, the set of measures for external constraints (coefficient $=0.074 ; t$ value $=2.83 ; p=0.005)$ has a positive and highly significant (1\%) impact relative to the internal measures.

The results for the estimation methods, regional differences, controls, and strength of results are qualitatively similar to the results for the main test. 
Table 2.7: Robustness test

\begin{tabular}{|c|c|c|}
\hline Fisher_Z & Coefficient & t-value \\
\hline \multicolumn{3}{|l|}{ Measurement of FP } \\
\hline MRK_MEASURE & $-0.051^{*}$ & -1.710 \\
\hline \multicolumn{3}{|l|}{ Measurement of FC } \\
\hline E_MEASURE & $0.074^{* * *}$ & 2.830 \\
\hline \multicolumn{3}{|l|}{ Estimation methods } \\
\hline FE & 0.008 & 0.331 \\
\hline GMM & 0.039 & 1.435 \\
\hline OLS & $0.030^{*}$ & 1.707 \\
\hline OTHER_EM & -0.035 & -1.390 \\
\hline RE & 0.009 & 0.302 \\
\hline CROSS_REG & -0.051 & -1.135 \\
\hline \multicolumn{3}{|l|}{ Regional difference } \\
\hline AUSTRALIA & -0.029 & -0.598 \\
\hline CROSS_COUNTRY & $0.110^{* *}$ & 2.360 \\
\hline EUROPE & 0.028 & 0.751 \\
\hline NORTH_AMERICA & -0.005 & -0.208 \\
\hline ASIA & $-0.103^{* * * *}$ & -2.785 \\
\hline \multicolumn{3}{|l|}{ Control } \\
\hline C_SIZE & -0.023 & -1.030 \\
\hline LEV & $-0.076^{*}$ & -1.830 \\
\hline GROWTH & $0.108^{*}$ & 1.720 \\
\hline FIRM_FE & 0.019 & 0.500 \\
\hline YEAR_FE & 0.004 & 0.120 \\
\hline INDUSTRY_FE & -0.017 & -0.440 \\
\hline TANGIBILITY & 0.045 & 1.220 \\
\hline $\mathrm{RD}$ & $-0.089^{*}$ & -1.720 \\
\hline LIQUIDITY & -0.049 & -1.540 \\
\hline M_PERFORMANCE & 0.020 & 0.430 \\
\hline COUNTRY_EFFECT & -0.036 & -1.100 \\
\hline C_GOVERNANCE & -0.044 & -0.550 \\
\hline \multicolumn{3}{|l|}{ Strength of result } \\
\hline S_SIZE & -0.011 & -0.490 \\
\hline J_QUALITY & $-0.245^{* * *}$ & -4.020 \\
\hline PUB_YEAR & -0.003 & -0.900 \\
\hline PUB_STATUS & $0.195^{* *}$ & 2.080 \\
\hline Y_COVERED & -0.001 & -0.430 \\
\hline CONSTANT & 7.448 & 0.890 \\
\hline Number of ES & \multicolumn{2}{|c|}{189} \\
\hline tau-squared $\left(\tau^{2}\right)$ & \multicolumn{2}{|c|}{.0080} \\
\hline I-squared & \multicolumn{2}{|c|}{$98.58 \%$} \\
\hline Adj $R^{2}$ & \multicolumn{2}{|c|}{$30.75 \%$} \\
\hline
\end{tabular}

Note: The Table reports regression analysis of sources of heterogeneity in the effect size for financial constraints on firm performance. The dependent variable is Fisher_Z. The variables are defined in Table 2.3. $* * * \mathrm{p}<0.01, * * \mathrm{p}<0.05,{ }^{*} \mathrm{p}<0.10$. 


\subsection{Conclusion}

This study examines the impact of financial constraints on firm performance. The findings show that, on average, there is a positive relationship between financial constraints and firm performance. However, there is significant variation in effect size (both in sign and significance) for the relationship between financial constraints and firm performance.

The findings from the meta-regression analysis suggest that variation in the results found in empirical studies is attributable principally, to differences in the choice of measures for both firm performance and financial constraints, to regional differences, and to measures indicating the strength of the results. The robustness test of the main meta-regression results supports the main results.

From the choice of firm performance measures, only stock return has a significant positive impact on the relationship relative to the mean level of impact among the choice of measures. ROA and ROE have significant negative impacts on the relationship between financial constraints and firm performance relative to the mean level of impact. The study also shows that the set of market based measures of firm performance has a significant negative impact on the relationship compared with the set of accounting-based measures.

In terms of the measures for financial constraints, the WW index has a highly significant positive impact relative to the mean level, whereas external finance and size have a significant negative impact relative to the mean. The results also show that the measures of external financial constraints have a highly significant 
positive impact on the relationship relative to the measures of internal financial constraints.

The study does not show any significant impact on the variation in effect sizes as a result of either choice of estimation method or choice of controls used in the sample studies. However, among the different regional areas addressed in the sample studies, Asia, Europe, and the block of countries used in Cross-country studies, all show a significant impact on the variation in effect size relative to the mean. Among the factors affecting the strength of the results, journal quality and publication status demonstrate a significant impact: journal quality a negative impact; and publication status a positive impact.

The study has an important policy implication as it can help to understand the differences in the direction of the relationship between financial constraints and firm performance in different country settings, and the reason behind the conflicting results across the studies. A high proportion of this study sample examined US firms, and focused on relatively short sample periods. This suggests that future research should provide additional evidence on other countries to enable decisions to be made based on the evidence unique to a particular country setting. Therefore, it also suggests the need for additional studies using recent data and, if history repeats, new measures of financial constraints will continue to be developed. 


\section{CHAPTER THREE}

\section{IMPACT OF DUAL-CLASS SHARE STRUCTURE ON FINANCIAL CONSTRAINTS}

\subsection{Introduction}

This study examines the impact of dual-class share structures on financial constraints. Financial constraints have significant impact on firm performance, therefore it is important to investigate this topic. Share structure is measured by the existence of a dual-class structure and also by excess voting rights and the proximity of the superior class shareholders ${ }^{11}$ in such structures. Although dualclass share structures have been shown to be associated with financial constraints under normal economic conditions, an important issue is whether the same relationship exists during an economic crisis period. In the main tests, three different measures of financial constraints are used to address the question of the impact of a dual-class share structure on financial constraints, and the global financial crisis is used as a case study to examine the effect of economic conditions on the impact.

As noted earlier, financial constraints, refer to the accessibility of funding required to undertake desired investments. Financial constraints have a range of influences, such as in decisions on investment, financing, and dividend policy,

\footnotetext{
${ }^{11}$ Superior class shareholders have greater voting rights than cash flow rights and
} therefore have a disproportionate influence on the major decisions of the firm. 
and on corporate value (Chen, 2016), and these impacts are consistent with the level of attention that researchers have given to the topic of financial constraints. However, it is important to note that this study focuses on financial constraints, not financial distress. ${ }^{12}$

A dual-class share structure denotes a complex ownership structure that assigns unequal voting rights ${ }^{13}$ to holders of different common stock classes. This structure separates voting rights from cash flow rights ${ }^{14}$ and can facilitate control for particular groups. Some U.S. stock exchanges (AMEX) have a restriction to preserve voting rights within the 10:1 ratio (Bentel and Walter, 2016). Owing to the growing number of dual-class IPOs, the impact of dual-class structure on corporate governance and investor protection has become a common topic for research. ${ }^{15}$

Dual-class share structure firms vary in terms of the gap between voting rights and cash flow rights. The voting-cash flow rights gap is referred as the "wedge". The higher the voting divergence, the more severe the agency problem.

\footnotetext{
${ }^{12}$ Financial distress refers to the inability of a company to meet its financial obligations as they mature (Beaver, Correia, and McNichols, 2011), whereas financial constraints refers to the unavailability of funding for desired investment.

${ }^{13}$ Voting rights signify shareholder's right to vote on important corporate policies such as: electing boards of directors, issuing securities, initiating corporate actions, making changes in corporate operations.

${ }^{14}$ Cash flow rights are the right of shareholders to receive a portion of a company's earnings.

${ }^{15} \mathrm{https}$ ///www.cfainstitute.org/-/media/documents/survey/apac-dual-class-sharessurvey-report.ashx
} 
According to Junzheng (2016), an increase in the voting-cash flow rights wedge results in a decrease in firm value. Claessens, Djankov, and Lang (2002) also illustrate similar results and argue that agency problems increase with increase in the voting-cash flow rights wedge. Therefore, the impact of the voting wedge on financial constraints is analysed to observe the agency conflict.

In many cases, directors and managers use a dual-class share structure to hold more voting power and effectively control the firm. Giving more power to insiders reduces management's accountability and facilitates managerial entrenchment ${ }^{16}$ which, in turn, hurts general investors. Gompers, Ishii, and Metrick (2009) demonstrate empirically that the wedge between insiders' cashflow rights and voting rights influences firm value negatively. Therefore, it is important to examine the impact of the proximity of the superior shareholders in dual-class firms.

There is an ongoing debate on the impact of dual-class share structures and the effects of the global financial crisis. To a remarkable extent, the impact of financial crises can be attributed to failures and weaknesses in corporate governance arrangements. Friedman et al. (2003) show a positive behavioural change in controlling shareholders during a crisis, affecting firm performance. This suggests that the global financial crisis moderates the relationship between dual-class share structures and the level of financial constraints. Many

\footnotetext{
${ }^{16}$ Managerial entrenchment refers to opportunistic behaviour whereby managers use the resources of the firm for their own interests.
} 
researchers find that there was an overall negative impact from the crisis (Brunnermeier, 2009; Erkens et al., 2012; Moore and Mirzaei, 2016), but there remains the question of why some firms had better access to finance during the crisis than others, despite all these firms being exposed to the same negative shock.

The only study that has examined the impact of dual class share structures on financial constraints is Lin et al. (2011a), and that study examines the impact of insiders' excess control rights on firm's external financial constraints. The authors find that firms having insiders with large excess control rights are more financially constrained. In this study, the impact of dual-class share structure on financial constraints is examined, not just by proximity of the superior class shareholders, but also by the existence of a dual-class structure and by the effects of excess voting rights. Thus, in contrast with the earlier study, this study (i) compares the impact of a dual-class share structure on financial constraints using three indicators of dual-class, (ii) uses three different measures of financial constraints, the KZ, WW and SA indexes (Kaplan and Zingales, 1997; Whited and Wu, 2006; Hadlock and Pierce, 2010), and (iii) the study uses data from a more recent period that includes the financial crisis period and, thus, tests for the moderating effect of the financial crisis on the impact of dual-class share structures.

Furthermore, in supplementary tests, (i) the HM index (Hoberg and Maksimovic, 2014) is used to examine whether dual-class firms are liquidity constrained, 
equity constrained, or debt constrained, (ii) firm age is tested for a possible moderating effect on the impact of dual-class structures, and (iii) the BLM index, a text based measure of financial constraints, is tested as an alternative to the KZ, WW and SA indexes, which are all based on firm-level characteristics.

\subsection{Prior Research Evidence and Hypotheses}

This section reviews the literature related to the impact of dual-class share structures and also reviews the literature on the effects of the global financial crisis.

\subsubsection{Dual-class Share Structures}

The corporate governance literature provides evidence of both positive and negative aspects of dual-class share structures (Morck, Shleifer, and Vishny, 1988) but, aside from Lin et al. (2011a), the literature relates to the impact of dual-class structures on firm value. In a dual-class share structure, a group of shareholders collectively own disproportionate voting rights to cash flow rights. They have influence over the firm's major decisions without having an equivalent investment in its equity. Therefore, an important criticism of dualclass share structures is that a potential conflict exists between the superior class shareholders and other shareholders, since the superior class shareholders have both the incentive and ability to divert corporate resources for private benefits, while bearing a relatively lower proportion of the financial consequences (Ang, Cole, and Lin, 2000; Chen, Chen, and Wei, 2009; Djankov, La Porta, Lopez-de- 
Silanes, and Shleifer, 2008; Grossman and Hart, 1988; Shleifer and Vishny, 1997). On the positive side, shareholders with voting rights excess to cash-flow rights may have both the ability and incentive to monitor management more closely (Shleifer and Vishny, 1986; 1997), thus, reducing agency costs (Jensen and Meckling, 1976). In contrast, if shareholders with excess control rights are insiders, the entrenchment hypothesis suggests that the effect is negative, owing to insider expropriation (Shleifer and Vishny, 1997).

Managers prioritize their decision-making to shareholders with excess voting rights (Bentel and Walter, 2016). Superior class shareholders' moral hazard is a vital issue in the corporate governance literature. They can make important decisions and expropriate assets via tunnelling, transfer pricing, asset stripping, investor dilution, and outright theft (Hoi and Robin, 2010). In line with this concern, several studies show a negative relationship between dual-class share structures and firm value (Gardiol, Gibson-Asner, and Tuchschmid, 1997; Jog and Riding, 1986; Hoi and Robin, 2010). Bloch and Hege (2003) find that unevenly distributed ownership is more likely to reduce monitoring effectiveness, a finding that indicates a negative relationship between dual-class share structures and firm value.

A significant number of studies across a range of countries provide substantial empirical evidence that the presence of dual-class share structures increases the cost of debt and creates agency problems (Aslan and Kumar, 2009; Gardiol et al., 1997; Lin, Ma, Malatesta, and Xuan, 2011b). In particular, the cost of debt 
increases, owing to increased monitoring problems and increased credit risk (Lin et al., 2011b). This, in turn, increases the financial constraints of a firm.

The study, thus, begins by testing the following hypothesis:

$\boldsymbol{H}_{1}$ : The presence of dual-class share structures increases the financial constraints of a firm.

Not only may the presence of a dual-class share structure matter, but the difference between the proportion of voting rights and cash flow rights: the voting wedge; increases the agency problem, and the increased agency problem has a negative impact on firm performance (Gompers et al., 2009; Hong, Kim, and Welker, 2017; Lin et al., 2011a; Masulis, Wang, and Xie, 2009; Wei and Zhang, 2008). Consider, for instance, 'Firm A' with a superior-class shareholder who owns $40 \%$ of shareholder voting power and $4 \%$ of shareholder cash flow rights, that is, 'Firm $\mathrm{A}$ ' has a 10:1 voting-cash flow rights ratio. On the other hand, 'Firm B' with a superior-class shareholder who owns $90 \%$ of shareholder voting power and $5 \%$ of shareholder cash flow rights, that is, 'Firm B' has an 18:1 voting-cash flow rights ratio. The superior-class shareholder of 'Firm B' will have more opportunity than the superior-class shareholder of firm A to engage in self-dealing ${ }^{17}$ activities at the expense of the shareholders with more cash flow

17 Self-dealing activities include outright theft, transfer pricing, investor dilution, executive perquisite, expropriation of corporate opportunities, investment in unprofitable projects for self-interest, asset sales to insiders or affiliated corporations at favourable prices, loan guarantees using the firm's assets as collateral and other self-serving financial transactions (Djankov et al., 2008; La Porta et al., 2000; Lin et al., 2011a; Shleifer and Vishny, 1997; Hoi and Robin, 2010). 
rights, as the superior-class shareholder has greater influencing power. This increases the agency problem and will increase financial constraints. The study, thus, tests the following hypothesis:

$\boldsymbol{H}_{2}$ : The greater the excess of control rights over cash flow rights of a dual-class firm, the more severe are the firm's financial constraints.

Several studies question the impact of insiders' influence on corporate performance. In dual-class share structures, members of the board of directors and top executives (insiders) are often empowered by their voting rights in excess of cash-flow rights to control the key corporate decisions (Gompers et al., 2009; Masulis et al., 2009). Chaudhuri and Seo (2012) illustrate that the divergence between insider and outsider shareholders' interests can decrease the value of the firm through various self-dealing activities by the superior class shareholders. Gompers et al. (2009) demonstrate empirically that the wedge between insiders' cash-flow rights and voting rights influences firm value negatively. Smith, Amoako-Adu, and Kalimipalli (2009) support the findings of Gompers et al. (2009) for a sample of Canadian firms. According to Hoi and Robin (2010), superior class shareholders in dual-class firms who are close to the locus of management have a greater opportunity to gain personal benefits, thus, lowering firm value. A CEO with excess control rights has more opportunities to pursue personal benefit than boards of directors or outsiders with excess voting rights. The probability of getting involved in self-dealing activities is, thus, higher. 
Lin et al. (2011a) further extend the previous literature and investigate the impact of insider shareholders in dual-class structures on financial constraints, and propose financial constraints as the channel between dual-class share structure and firm value. The authors argue that the insiders' voting rights excess to cash flow rights, increases firms' financial constraints, which eventually decreases firm value by preventing firms from funding all desired investments. Owing to the agency conflict, outside investors (both shareholders and creditors) are less willing to invest in dual-class firms where insiders hold excess voting rights and, in particular, where outsider investors face the risk of expropriation (La Porta, Lopez-de-Silanes, Shleifer, and Vishny, 2000). The study therefore, tests the following hypothesis:

H3: Financial constraints increase with the proximity of the superior-class shareholders of dual-class share structure.

\subsubsection{Global Financial Crisis and Corporate Finance}

The 2007/09 global financial crisis is commonly regarded as having been the worst economic crisis since the Great Depression of the 1930s (Eichengreen and O'rourke, 2009; Eigner and Umlauft, 2015; Temin, 2010). It began in 2007 and quickly became a giant credit crisis with the collapse of Lehman Brothers in September 2008. According to the International Monetary Fund, big American banks, as well as European banks, lost more than $\$ 1$ trillion from toxic assets and bad loans from the beginning of 2007 until the end of 2009 (Kale et al., 
2017). By mid-2008, the US's subprime mortgage market crisis severely affected financial institutions worldwide.

According to some studies, firms that are dependent on external financing suffer more during financial crises (Braun and Larrain, 2005; Opler and Titman, 1994; Senbet and Wang, 2012). Thus, firms that were not financially constrained, or only moderately constrained, before a crisis might become severely financially constrained during a financial crisis period. It is consistent with the concept that firms can face financial constraints, not only for firm-specific reasons but also from macroeconomic factors such as the global financial crisis. Using a panel of US firms, Duchin, Ozbas, and Sensoy (2010) extend the earlier studies and find that the financial crisis affected corporate investments adversely by reducing the supply of external finance for non-financial firms. The authors also show that the negative impact was higher for more financially constrained firms (Duchin et al., 2010). Likewise, Mercatanti, Mäkinen, and Silvestrini (2017) show a similar result in a study on a sample of European firms.

However, Friedman et al. (2003) show that a tremendous negative shock (such as a financial crisis) may impact the behaviour of controlling shareholders in pyramidal ownership structures positively. The Friedman et al. (2003) view: the propping theory; argues that firms with controlling shareholders may undergo smaller stock price declines during a crisis, because the controlling shareholders provide support to the firm or, at least, postpone their opportunistic behaviour, to prevent the firm from financial distress. Saghi-Zedek and Tarazi (2015) 
strongly support the propping theory and show, in a European setting, that although the presence of a controlling shareholders had a negative impact on firm performance before and after the crisis period, it improved profitability and mitigated default risk during the financial crisis period.

Although the propping theory is based on the pyramidal ownership structure, it exemplifies the degree of separation in control-ownership, and the behavioural change of superior shareholders. Thus, a positive behavioural change by a superior class shareholder in dual-class share structures can be expected during a severe crisis such as the global financial crisis. Owing to this potential for supportive behavior by the superior class shareholder during the global financial crisis, potential shareholders and creditors might be more interested in investing in dual-class firms and, thus, decreasing a firm's financial constraints. The study thus tests the following hypotheses:

H4: The global financial crisis moderated the effects of dual-class share structures on financial constraints.

$\boldsymbol{H}_{5}$ : The global financial crisis moderated the effects of excess voting rights on financial constraints.

$\boldsymbol{H}_{6}$ : The global financial crisis moderated the effects of proximity of the superior class shareholders on financial constraints. 


\subsection{Research Design}

This section of the study discusses the research design used to test the hypotheses. It states the models applied, discusses the measures used for the different variables, and discusses the construction of the sample used for the study.

\subsubsection{Test Methods}

To test the hypotheses, the following regression models are employed.

Model 1: To test the impact of dual-class share structure on financial constraints $\left(\mathrm{H}_{1}\right)$

FIN_CONS $_{i t}=\beta_{o}+\beta_{1}$ DUAL_CLASS $i t+\sum$ Control $_{i t}+f e_{i t}+\mu_{i t}$

where,

$\begin{array}{lll}\text { FIN_CONS } & = & \text { Financial constraints (dependent } \\ & = & \text { variable) } \\ \text { DUAL_CLASS } & = & \text { Fual-class share structure (test } \\ & & \\ \text { Control } & = & \text { Fixed effects } \\ \mathrm{fe} & = & \text { Error term }\end{array}$


Model 2: To investigate the impact of excess voting rights over cash flow rights on financial constraints of a firm $\left(\mathrm{H}_{2}\right)$

FIN_CONS $_{i t}=\beta_{o}+\beta_{2} V_{-} W E D G E_{i t}+\sum$ Control $_{i t}+f e_{i t}+\mu_{i t}$

where,

V_WEDGE $\quad=\quad$ Divergence between cash flow rights and voting rights

The remaining variables are as defined in Model

1.

Model 3: To investigate whether proximity of the superior shareholders has an impact on the financial constraints of a firm $\left(\mathrm{H}_{3}\right)$

$F I N \_C O N S_{i t}=\beta_{o}+\beta_{3} I N S I D E R \_S H i t+\sum$ Control ${ }_{i t}+f e_{i t}+\mu_{i t}$

where,

INSIDER_SH = $\quad$ Proximity of superior-class shareholder

The remaining variables are as defined in

Model 1.

Model 4: To test the effect of the global financial crisis on the relationship between dual-class share structure and financial constraints $\left(\mathrm{H}_{4}\right)$

FIN_CONS $_{i t}=\beta_{o}+\beta_{1}$ DUAL_CLASS $S_{i t}+\beta_{2} G F C+\beta_{3} G F C * D U A L \_C L A S S_{i t}+$ $\sum$ Control $_{i t}+f e_{i t}+\mu_{i t}$ 
Model 5: To test the effect of the global financial crisis on the relationship between voting wedge and financial constraints $\left(\mathrm{H}_{5}\right)$

$F I N_{-} C O N S_{i t}=\beta_{o}+\beta_{1} V_{-} W E D G E_{i t}+\beta_{2} G F C+\beta_{3} G F C * V_{-} W E D G E_{i t}+\sum$ Control $_{i t}$ $+f e_{i t}+\mu_{i t}$

Model 6: To test the effect of the global financial crisis on the relationship between the proximity of superior class shareholders and financial constraints $\left(\mathrm{H}_{6}\right)$

$F I N \_C O N S_{i t}=\beta_{o}+\beta_{1} I N S I D E R \_S H_{i t}+\beta_{2} G F C+\beta_{3} G F C * I N S I D E R \_S H_{i t}+$ $\sum$ Control $_{i t}+f e_{i t}+\mu_{i t}$

where,

GFC $\quad=\quad$ Global financial crisis

Remaining variables are as defined in Models

1,2 , and 3 .

\subsubsection{Measures of the Variables}

This section discusses the measures used for the (i) dependent variable, (ii) test variable, and (iii) control variables.

\subsubsection{Dependent Variable}

The baseline tests use three different measures of financial constraints: the KZ, WW, and SA indexes. In the additional tests, the HM and BLM indexes are also 
used. The KZ, WW, and SA indexes are all based on firm-level characteristics whereas the HM and BLM indexes are text based.

The study uses continuous measures of financial constraints for the tests. Many of the papers that have examined the impact of financial constraints have used a dummy as the measure of financial constraints. However a dummy measure fails to reflect that some firms are highly constrained, some firms are somewhat constrained, and some firms might be deeply constrained. ${ }^{18}$

\section{(i) KZ Index as a Measure of Financial Constraints}

The KZ index (Kaplan-Zingale's index) is a relative measure of reliance on access to finance. Firms with higher $\mathrm{KZ}$ index scores are more financially constrained. Using five firm-level characteristics, the $\mathrm{KZ}$ index is calculated as follows:

KZ Index $=(-1.001909 \times$ Cash Flows $/ K)+0.2826389 x$ Tobins' $Q+3.139193$ x Debt / Total Capital + (-39.3678 x Dividends / K $)+(-1.314759$ x Cash / K $)$

\footnotetext{
${ }^{18}$ See Hoberg and Maksimovic (2015)
} 
where,

Cash $=$ Income before extraordinary items + Total

Flows depreciation and amortization

$\mathrm{K}$

$=$ One-year lagged property, plant \& equipment

Tobins'Q

$=\quad$ (Market capitalization + total shareholder's equity - Book value of common equity deferred tax assets)/Total shareholder's equity

Debt

$=\quad$ Total long-term debt + Notes payable + Current portion of long-term debt

Total

$=\quad$ Total Debt + total Equity (COMPUSTAT -

capital total invested capital)

Dividends

$=\quad$ Total cash dividends paid (common and preferred)

Cash

$=\quad$ Cash and short-term investments

(ii) WW Index as a Measure of Financial Constraints

The index was developed by Whited and Wu (2006). Whited and Wu (2006) argue that the firm level factors used in the $\mathrm{KZ}$ index do not represent financial constraints faithfully. They argue that the Tobin's Q variable in the KZ index, contains a great deal of measurement error. Also, Whited and Wu (2006) argue that firms categorized as more constrained by the $\mathrm{KZ}$ index have more analyst 
coverage, more bond ratings, higher sales growth, and lower industry sales growth than unconstrained firms and, hence, the index does not indicate properly the degree of external financial constraints of a firm. Whited and $\mathrm{Wu}$ (2006), thus, propose the following index, the 'WW index', which is calculated as follows:

$W W_{i t}=-0.091 C F_{i t}-0.062$ DIVPOS $_{i t}+0.021$ TLTD $_{i t}-0.044 L{ }^{2} T A_{i t}+0.102$ $I S G_{i t}-0.035 S G_{i t}$

where,

CF $\quad=\quad$ Cash flow divided by total assets

DIVPOS = $\quad$ A dummy variable equal to 1 if the firm pays

dividends and 0 otherwise

TLTD $=\quad$ Long-term debt divided by total assets

LNTA $\quad=\quad$ The natural log of total assets

ISG $\quad=\quad$ Firm's three-digit SIC code industry annual

sales growth, and

$S G \quad=\quad$ Firm's annual sales growth .

(iii) SA Index as a Measure of Financial Constraints

The SA index was developed by Hadlock and Pierce (2010) using firm size and age. A higher SA index indicates a higher degree of financial constraints. Hadlock and Pierce (2010) express doubt about all the factors considered in the KZ index and the WW index, and provide evidence that some of the factors 
included in the indexes are not significantly related to constraints. Although two of the factors, leverage, and cash flow, from the $\mathrm{KZ}$ and the $\mathrm{WW}$ indexes, are significantly related to financial constraints, these variables may lead to underdetection of the presence of constraints in firms with low leverage or low cash flow. ${ }^{19}$ The SA index is calculated as follows:

$$
S A_{i t}=-0.737 S I Z E_{i t}+0.043\left(S I Z E_{i t}\right)^{2}-0.040 A G E_{i t}
$$

where,

SIZE $\quad=\quad$ the natural log of inflation adjusted book assets, $A G E \quad=\quad$ the number of years the firm is listed in COMPUSTAT

Here, size is replaced with $\log (\$ 4.5$ billion) and age with thirty-seven years if the observed values exceed these thresholds.

\subsubsection{Test Variable}

The measure of the test variable for $\mathrm{H}_{1}$ is the existence of dual-class share structure. The variable DUAL_CLASS is a dummy variable equal to 1 if the firm has a dual-class share structure and else 0. Many of the earlier studies follow the approach of Gompers et al., (2009) to identify firms with dual-class share structures. This approach identified dual-class firms by using data from the SDC,

\footnotetext{
${ }^{19}$ See Hadlock and Pierce (2010) for more details.
} 
S\&P COMPUSTAT, CRSP, and IRRC (the Investor Responsibility Research Center) databases.

Howell (2010) finds sample selection problems with Gompers's sample selection approach. In particular, Howell (2010) argues that the Gompers et al. (2009) method would identify only $15 \%$ of firms with dual-class share structures and would identify the firms with the smallest difference between voting rights and cash-flow rights. Howell (2010) uses the COMPUSTAT class test, CRSP code test, SDC test, IPO test, CRSP/COMPUSTAT shares outstanding test to identify dual-class firms. Thus, in order to obtain a sample likely to be more representative of the actual population of dual-class firms, the data on dual-class firms were hand-collected from the primary source (form DEF 14A) and also drew on the COMPUSTAT database. A significant and positive coefficient on DUAL_CLASS in the test results would support $\mathrm{H}_{1}$.

To test $\mathrm{H}_{2}$, voting wedge, $\mathrm{V}_{-}$WEDGE, is the measure used for the test variable and is calculated as the difference between the voting rights and cash-flow rights in a dual-class share structure. If the test results show a significant and positive coefficient on $\mathrm{V}_{-}$WEDGE, that would support $\mathrm{H}_{2}$. To test $\mathrm{H}_{3}$, a dummy variable, INSIDER_SH, is used to indicate the proximity of superior class shareholders of firms in the sample of firms with dual-class share structure,. The dummy equals 1 if the superior shareholders are insiders (Directors or CEO) of the firm, else 0. A significant and positive coefficient on INSIDER_SH would provide support for $\mathrm{H}_{3}$. 
To test $\mathrm{H}_{4}, \mathrm{H}_{5}$ and $\mathrm{H}_{6}$ a dummy variable, GFC, is used to indicate the global financial crisis years. The NBER turning point dates for the U.S. economy is adopted and, thus, the period from 2007 to 2009 is considered as being the crisis period. $^{20}$ Thus, GFC equals 1 for the years 2007-2009 or else 0. A significant negative coefficient on the interaction for GFC with the measure of dual-class share structure would provide support for $\mathrm{H}_{4}, \mathrm{H}_{5}$, and $\mathrm{H}_{6}$.

\subsubsection{Control Variables}

The study includes a set of control variables that represent firm specific characteristics. These variables control for firm-level variation associated with changes in dual-class share structures and financial constraints. Key control variables are credit rating, $R \& D$ expenses, capital intensity, profitability, and industry. The choice of control variables is guided by relevant previous studies (for example, Lin et al., 2011a; Hoberg and Maksimovic, 2014; Hoi and Robin, 2010; Whited and $\mathrm{Wu}, 2006)$.

The presence of a credit rating reduces information asymmetry (Lin et al., 2011a) owing to the close monitoring and publication of detailed firm-level information in rating reports (Heller, 2015). Norden and Weber (2004) argue that equity investors are also sensitive to credit ratings as they provide signals to outsider investors. Therefore, the impact of CR_DUMMY on financial constraints would be expected to be negative as the existence of the credit rating of a firm is likely to result in lower financial constraints (Lin et al., 2011a). Following Lin et al.

\footnotetext{
${ }^{20} \mathrm{https}: / / \mathrm{www}$.nber.org/research/data/us-business-cycle-expansions-and-contractions
} 
(2011a), the study use credit rating dummy to capture the presence of credit rating of a firm.

The presence of R\&D expenditure (RD_DUMMY) indicates the potential growth of a firm. Therefore, the effect of RD_DUMMY is negative on financial constraints would be expected to be negative as more financially constrained firms are less likely to invest in $\mathrm{R} \& \mathrm{D}$ projects $(\mathrm{Li}, 2011) .{ }^{21}$ Following Limanl1 (2015), this study use R\&D dummy to capture the presence of R\&D expenditure.

Capital intensity is defined as the ratio of capital expenditure to net sales. Here, capital intensity represents potential investment opportunities, and a negative association between capital intensity and financial constraints is expected (Hoberg and Maksimovic, 2014) as more constrained firms are unable to invest owing to the lack of funding.

In the test results, MTB would be expected to have a positive coefficient ${ }^{22}$ and profitability (ROA) a negative coefficient, as growing firms and firms with lower profitability are likely to be more constrained. Sales growth is expected to have a negative impact on financial constraints as constrained firms tend to have lower sales growth (Whited and $\mathrm{Wu}, 2006$ ). Finally, the 'SIC code' is used to group and control for industry. The measures for all the variables are defined in Table 3.1.

${ }^{21}$ According to Li (2011), if a firm cannot raise enough funds to conduct the required research, it has to suspend/discontinue the project.

${ }^{22}$ According to Whited and $\mathrm{Wu}$ (2006) the BTM is higher for less constrained firms as value stocks are on average less likely to be financially constrained as compared to growth stocks. 
TABLE 3.1: Variable definition

\begin{tabular}{|c|c|c|c|}
\hline Variable & Description & Definition & $\begin{array}{l}\text { Data } \\
\text { source }\end{array}$ \\
\hline FIN_CONS & $\begin{array}{l}\text { Financial } \\
\text { constraints }\end{array}$ & $\begin{array}{l}\text { Financial constraints are measured by three indexes: } \\
\text { (1)KZ INDEX: } \\
\mathrm{KZ}_{\mathrm{it}}=(-1.001909 \times \mathrm{x} \text { Cash Flows / K })+0.2826389 \times \\
\text { Tobins' Q }+3.139193 \times \mathrm{x} \text {-bt / Total Capital }+(- \\
39.3678 \times \text { Dividends / K })+(-1.314759 \times \text { Cash / K }) \\
(2) W W \text { INDEX: } \\
\mathrm{WW}_{\mathrm{it}}=-0.091 * \mathrm{CF}_{\mathrm{it}}-0.062 * \mathrm{DIVPOS}_{\mathrm{it}}+0.021 \\
* \mathrm{TLTD}_{\mathrm{it}}-0.044 * \mathrm{LNTA}_{\mathrm{it}}+0.102 * \mathrm{ISG}_{\mathrm{it}}-0.035 * \mathrm{SG}_{\mathrm{it}} \\
\text { (3) SA INDEX: } \\
\mathrm{SA}_{\mathrm{it}}=-0.737 \mathrm{SIZE}_{\mathrm{it}}+0.043\left(\mathrm{SIZE}_{\mathrm{it}}\right)^{2}-0.040 \mathrm{AGE}_{\mathrm{it}}\end{array}$ & COMPUSTAT \\
\hline DUAL_CLASS & $\begin{array}{l}\text { Dual-class } \\
\text { share } \\
\text { structure }\end{array}$ & $\begin{array}{l}\text { A dummy variable that equals } 1 \text { if the firm has a dual- } \\
\text { class share structure and else } 0, \text { for firm } i \text { in year } t .\end{array}$ & $\begin{array}{l}\text { COMPUSTAT } \\
\text { CRSP, SEC } \\
\text { reporting }\end{array}$ \\
\hline V_WEDGE & $\begin{array}{l}\text { Voting-cash } \\
\text { flow rights } \\
\text { divergence } \\
\end{array}$ & $\begin{array}{l}\text { Log of the divergence between cash flow rights and } \\
\text { voting rights of firm i in year } t \text {. }\end{array}$ & $\begin{array}{l}\text { SEC report; } \\
\text { Form DEF 14A } \\
\text { - EDGAR }\end{array}$ \\
\hline INSIDER_SH & $\begin{array}{l}\text { The } \\
\text { proximity of } \\
\text { controlling } \\
\text { shareholders }\end{array}$ & $\begin{array}{l}\text { A dummy variable that equals } 1 \text { if the shareholders with } \\
\text { highest voting rights are insiders (i.e., director of CEO) } \\
\text { of the firm and else } 0 \text {, for firm } i \text { in year } t \text {. }\end{array}$ & $\begin{array}{l}\text { SEC report; } \\
\text { Form DEF 14A } \\
\text { - EDGAR }\end{array}$ \\
\hline CR_DUMMY & Credit rating & $\begin{array}{l}\text { A dummy variable that equals } 1 \text { if the firm has } S \& P \\
\text { credit rating in year } t \text { else } 0 \text {, for firm } i \text { in year } t \text {. }\end{array}$ & COMPUSTAT \\
\hline & & & \\
\hline
\end{tabular}




\begin{tabular}{|c|c|c|c|}
\hline Variable & Description & Definition & $\begin{array}{l}\text { Data } \\
\text { source }\end{array}$ \\
\hline RD_DUMMY & $\begin{array}{l}\text { Research and } \\
\text { Development } \\
\text { Expense }\end{array}$ & $\begin{array}{l}\text { A dummy variable that equals } 1 \text { if firm } i \text { in year } t \text { has } \\
R \& D \text { expense and else } 0 \text {, for firm } i \text { in year } t \text {. }\end{array}$ & COMPUSTAT \\
\hline CAPITAL_INT & $\begin{array}{l}\text { Capital } \\
\text { intensity }\end{array}$ & $\begin{array}{l}\text { The ratio of capital expenditure to net sales of firm } \mathrm{i} \text { in } \\
\text { year } \mathrm{t} \text {. }\end{array}$ & COMPUSTAT \\
\hline$R O A$ & $\begin{array}{l}\text { Return on } \\
\text { Asset }\end{array}$ & $\begin{array}{l}\text { The ratio of income before extraordinary items to total } \\
\text { assets of firm } i \text { in year } t \text {. }\end{array}$ & COMPUSTAT \\
\hline SALES_GROWTH & $\begin{array}{l}\text { Sales } \\
\text { Growth }\end{array}$ & $\begin{array}{l}\text { For firm } \mathrm{i} \text { in year } \mathrm{t} \text {, the change in sales from the } \\
\text { previous year }\end{array}$ & COMPUSTAT \\
\hline$M T B$ & $\begin{array}{l}\text { Market to } \\
\text { Book }\end{array}$ & $\begin{array}{l}\text { The ratio of Market value on equity to book value on } \\
\text { equity of firm i in year t }\end{array}$ & COMPUSTAT \\
\hline GFC & $\begin{array}{l}\text { Global } \\
\text { financial } \\
\text { crisis }\end{array}$ & $\begin{array}{l}\text { A dummy variable that equals } 1 \text { if the period is the crisis } \\
\text { period } 2007 \text { to } 2009 \text { and else } 0 \text {, for firm } i \text { in year } t \text {. }\end{array}$ & COMPUSTAT \\
\hline$I N D \_F E$ & $\begin{array}{l}\text { Industry } \\
\text { fixed effects }\end{array}$ & Industry (SIC) fixed effect. & COMPUSTAT \\
\hline$Y E A R \_F E$ & $\begin{array}{l}\text { Year fixed } \\
\text { effects }\end{array}$ & Year (t) fixed effect. & $\begin{array}{l}\text { COMPUSTAT } \\
\text { (Fiscal Year) }\end{array}$ \\
\hline$H M$ index & $\begin{array}{l}\text { Alternative } \\
\text { measure of } \\
\text { financial } \\
\text { constraints }\end{array}$ & $\begin{array}{l}\text { For an additional test: } \\
H M \text { INDEX: A text based measure of financial } \\
\text { constraints, which contains four scores: "Delay } \\
\text { Investment Score (D_INV_SC)," "Equity Focus Delay } \\
\text { Investment Score (E_D_INV_SC)," "Debt Focus Delay } \\
\text { Investment Score (D_D_INV_SC)" and the "Private } \\
\text { Placement Focus Delay Investment Score }\end{array}$ & $\begin{array}{l}\text { Authors' } \\
\text { website }\end{array}$ \\
\hline
\end{tabular}




\begin{tabular}{|c|l|l|c|}
\hline & & $\begin{array}{l}\text { (PP_D_INV_SC)". Each of the scores is used seperately } \\
\text { to analyse the dimensions of financial constraints. }\end{array}$ & \\
\hline BLM_INDEX: & $\begin{array}{l}\text { Alternative } \\
\text { measure of } \\
\text { financial } \\
\text { constraints }\end{array}$ & $\begin{array}{l}\text { For an additional test: } \\
\text { BLM INDEX: A text based measure calculated as: } \\
\text { BLM } \\
\text { of wordsit }\end{array}$ & $\begin{array}{l}\text { Authors' } \\
\text { website }\end{array}$ \\
\hline
\end{tabular}

Note: Table 3.1 gives detailed definitions of the variables. 


\subsubsection{Data}

This section describes the sample for the study which covers US non-financial publicly traded firms over the period 2002-2018. In order to avoid the dotcom crisis period, which effected US market in 2001, the study includes data from 2002. Also, Lin et al. (2011a) paper analyses the sample period from 1994-2002. As this study extends Lin et al. (2011a), the sample period begins from 2002.

The data is collected from a number of different sources.

\subsubsection{Sample selection}

The data for calculation of the $\mathrm{KZ}, \mathrm{WW}$, and $\mathrm{SA}$ indexes is collected from COMPUSTAT. The values of the text-based HM and BLM indexes were obtained from the publicly available data provided by the authors on their website. ${ }^{23}$

The initial test variable data set was obtained as follows:

- The first step was to identify from the EDGAR database (website ${ }^{24}$ ) the firms that filed an annual proxy statement (Form DEF 14A) during the period 2002

${ }^{23} \mathrm{http} / / /$ www-bcf.usc.edu/ hoberg/MaxDataSite/index.html and https://sraf.nd.edu/data/

${ }^{24}$ See https://www.sec.gov/Archives/edgar/full-index/ 
to 2018. The forms were downloaded and the company name and CIK were recorded. After removing duplicates, there were 15,772 firms.

- Delisted and inactive firms, foreign-owned firms, and financial firms (SIC code between 6000-6799) were removed, resulting in a reduced sample of 4,025 firms.

- The sample was then checked against the DEF 14A forms until 2017 and after deleting firms that actually had a single class of shares and also firms that had more than two classes ('multiple classes') of shares, this left 251 dual-class firms.

- This reduced sample of 251 was then merged with the set of firms in COMPUSTAT with the terms "Class A" or "Class B" at the end of the firm name. This resulted in an additional 130 firms. However, when checked against firm information in EDGAR, this additional set reduced by 72 for being single class or with a missing form DEF 14A, and further reduced by 58 for having multiple class share structures, thus, finally yielding 51 dualclass firms. There was, therefore, in total, 302 dual-class firms and over the period 2002 to 2018 and this provided 1,939 firm-year observations.

- For each firm-year observation, the voting wedge was calculated and recorded together with the proximity of the superior shareholders (insider vs external). 
Data on the firm-level control variables; CR_DUMMY ${ }^{25}$, RD_DUMMY, CAP_INTENSITY, ROA, SALES_GROWH, and MTB were collected from COMPUSTAT.

The steps in the process of constructing the final sample for the baseline tests are detailed in Table 3.2, Panel A. The process began by merging the datasets for the $\mathrm{KZ}$ index, WW index, SA index, and BLM index ${ }^{26}$, the test variable dataset, and the control variables, and) from 2002-2018. This produced 223,856 firmyear observations. After dropping missing values for the KZ, WW, SA and BLM indexes, firm-year observations on financial institutions, and missing values on the measures of the control variables, the sample reduced to 38,666 firm year observations. After applying the STATA PSM procedure on firm size and the control variables this produced a final test sample of 2,466 firm year observations comprising 1,233 firm- year observations on dual class firms and 1,233 matched firm year observations.

To avoid the undesirable influence of outliers, the dependent and control variables were winsorized for the extreme $1 \%$ of their distributions (except

${ }^{25}$ Credit rating data for 2018 was collected from S\&P Capital IQ as COMPUSTAT data for 2018 was not updated.

${ }^{26}$ Data on the BLM index was available for the whole of the test period, 2002-2018, and therefore for the sake of comparability of the test results using the BLM index vs the KZ, WW and SA indexes, the BLM index was included in the filtering of the dataset. In contrast, data on the HM index was available only to 2015 and, therefore, the test sample for the HM tests was constructed by repeat of the process described in Table 3.2, Panel A but with HM as a filter rather than other indexes. 
dummy variables). However, because of extreme dispersion for sales growth and ROA, those variables were winsorized at $5 \%$ of their distributions.

Table 3.2 Panel A: Sample selection procedure

Selection process

After merging all the dataset for the period 2002-2018

(drop) duplicates

Remaining sample

(drop) Missing KZ index

Remaining Sample

(drop) Missing WW index

Remaining Sample

(drop) Missing SA index

Remaining Sample

(drop) Missing BLM index

Remaining Sample

(drop) financial institutions (SIC 6000-6999)

Remaining Sample

(drop) Missing control variable observations

Sample for the use of PSM

After Using PSM:

Dual-class firm-year observations

Non-dual-class firm-year observations
No of Firm-year observations 223,856

$(74,796)$

$\underline{149,060}$

$(91,177)$

$\underline{57,883}$

$(7,114)$

$\underline{50,769}$

$\underline{50,740}$

$\underline{43,149}$

$\underline{38,666}$

1,233

1,233

Final sample for the baseline analysis 


\subsubsection{Description of the Sample}

Table 3.2, Panel B, shows the distribution of the sample observations over the sample period, 2002-2018. The year 2018 has the highest number of firm-year observations (200) and 2003 the lowest number of observations (32).

Table 3.2 Panel B: Distribution by year

\begin{tabular}{ccc}
\hline Year & $\begin{array}{c}\text { No. of firm- } \\
\text { year } \\
\text { observations }\end{array}$ & $\begin{array}{c}\text { Percentage } \\
(\%)\end{array}$ \\
\hline 2002 & 33 & 1.34 \\
2003 & 32 & 1.30 \\
2004 & 72 & 2.92 \\
2005 & 98 & 3.97 \\
2006 & 117 & 4.74 \\
2007 & 128 & 5.19 \\
2008 & 133 & 5.39 \\
2009 & 197 & 7.99 \\
2010 & 183 & 7.42 \\
2012 & 156 & 6.33 \\
2013 & 168 & 6.81 \\
2014 & 194 & 7.87 \\
2015 & 172 & 6.97 \\
2016 & 197 & 7.99 \\
2017 & 193 & 7.83 \\
2018 & 193 & 7.83 \\
Total & 200 & 8.11 \\
\hline
\end{tabular}

Notes: Table 3.2, Panel B, shows the sample distribution by year.

Table 3.2, Panel C, shows that the firm-year observations come from a variety of industries, with the largest number of observations from the services industry (840, $34 \%)$. 
Table 3.2 Panel C: Distribution by industry

\begin{tabular}{lcc}
\hline Industry Group & $\begin{array}{c}\text { No. of firm- } \\
\text { year } \\
\text { observations }\end{array}$ & $\begin{array}{c}\text { Percentage } \\
(\%)\end{array}$ \\
\hline Agriculture, Forestry & 4 & 0.16 \\
and Fishing & 37 & 1.50 \\
Mining & 8 & 0.32 \\
Construction & 712 & 28.87 \\
Manufacturing & 401 & 16.26 \\
Transportation and & 160 & 6.49 \\
Communications group & 294 & 11.92 \\
Wholesale Trade & 840 & 34.06 \\
Retail Trade & 10 & 0.41 \\
Services & $\mathbf{2 , 4 6 6}$ & $\mathbf{1 0 0 . 0 0}$ \\
Non-classifiable &
\end{tabular}

Notes: Table 3.2, Panel C, shows the sample distribution by industry.

\subsection{Result and Discussion}

This section provides descriptive statistics on the sample data and discusses the test results and implications for the hypotheses.

\subsubsection{Descriptive Statistics and Correlation Analysis}

Descriptive statistics on the sample are reported in panel D and Panel E of Table 3.2. There are 2,466 firm-year observations over the study period from 2002 to 2018. The mean (median) of the KZ, WW, and SA Indexes are -10.98 (-1.699), $-0.392(-0.378)$, and $-1.241(-2.637)$. The mean of DUAL_CLASS for the sample is 0.5 as there are 1,233 firm-year observations in the sample with a dual-class share structure. The mean of voting wedge is 7.93 (thus 15.86 in the dual-class structure component of the sample), and indicates that the voting wedge on 
average is not very high, which is expected in the US market owing to its high level of investor protection. The mean of INSIDER_SH for the sample is 0.401(thus, 0.802 in the dual-class structure component of the sample) and indicates that 988 observations in the sample were on firms with insiders as the superior shareholders. ${ }^{27}$

The mean of CR_DUMMY indicates that almost 695 observations are on firms with an S\&P credit rating. The mean of RD_DUMMY indicates that almost 974 observations are on firms that engage in R\&D. Mean (median) of CAPITAL_INT is 0.029 (0.033), which indicates that on average the observations in the sample have low capital intensity. ROA has a mean (median) of $-0.019(0.035)$, which indicates that a high number of the firms in the sample are loss making. SALES_GROWTH has a mean (median) of 0.088 (.054) and MTB a mean (median) of 1.01 (1) which, together, suggest that most of the observations in the sample are on growing firms with reasonable prospects.

\footnotetext{
${ }^{27}$ The largest superior class shareholder is the insider group.
} 
TABLE 3.2 Panel D: Summary statistics

\begin{tabular}{|c|c|c|c|c|c|c|}
\hline Variable & $\mathrm{N}$ & Mean & Median & SD & Min & $\operatorname{Max}$ \\
\hline$\overline{\text { KZ_INDEX }}$ & 2466 & -10.98 & -1.699 & 44.451 & -358.88 & 259.329 \\
\hline WW_INDEX & 2466 & -.392 & -.378 & .201 & -1.264 & 1.1 \\
\hline SA_INDEX & 2466 & -1.241 & -2.637 & 5.289 & -4.475 & 20.395 \\
\hline DUAL_CLASS & 2466 & .5 & 0 & .5 & 0 & 1 \\
\hline V_WEDGE & 2466 & 7.93 & 0 & 8.011 & 0 & 21.698 \\
\hline INSIDER_SH & 2466 & .401 & 0 & .49 & 0 & 1 \\
\hline CR_DUMMY & 2466 & .282 & 0 & .449 & 0 & 1 \\
\hline RD_DUMMY & 2466 & .395 & 0 & .489 & 0 & 1 \\
\hline CAPITAL_INT & 2466 & .029 & .033 & .106 & 0 & 2.46 \\
\hline ROA & 2466 & -.019 & .035 & .212 & -1.183 & .169 \\
\hline $\begin{array}{l}\text { SALES_GROWT } \\
\mathrm{H}\end{array}$ & 2466 & .088 & .054 & .247 & -.392 & 1 \\
\hline MTB & 2466 & 1.01 & 1 & .15 & .578 & 2.108 \\
\hline GFC & 2466 & .186 & 0 & .389 & 0 & 1 \\
\hline
\end{tabular}

Note: KZ, WW, and SA indexes are the measures for financial constraints (winsorized at 1\%). Capital intensity, and sales growth are in millions of dollars. Refer to Table 3.1 for detailed definitions of the variables. 
TABLE 3.2 Panel E: Summary statistics by dual-class share structure

\section{Non-Dual-Class share structure}

\begin{tabular}{lrrrrr}
\hline & $\mathrm{N}$ & Mean & SD & Min & Max \\
\hline KZ_INDEX & 1233 & -13.063 & 51.096 & -358.88 & 259.329 \\
WW_INDEX & 1233 & -.401 & .235 & -1.264 & 1.1 \\
SA_INDEX & 1233 & -1.03 & 5.633 & -4.475 & 20.395 \\
CR_DUMMY & 1233 & .273 & .445 & 0 & 1 \\
RD_DUMMY & 1233 & .423 & .494 & 0 & 1 \\
CAPITAL_INT & 1233 & .052 & .112 & 0 & 2.46 \\
ROA & 1233 & -.018 & .225 & -1.183 & .169 \\
SALES_GROWT & 1233 & .092 & .264 & -.392 & 1 \\
H & 1233 & 1.009 & .159 & .578 & 2.108 \\
MTB & & & & & \\
& & & &
\end{tabular}

Dual-class share structure

\begin{tabular}{lccccr}
\hline & $\mathrm{N}$ & Mean & SD & Min & Max \\
\hline KZ_INDEX & 1233 & -8.896 & 36.521 & -358.88 & 259.329 \\
WW_INDEX & 1233 & -.383 & .16 & -1.264 & 1.1 \\
SA_INDEX & 1233 & -1.453 & 4.915 & -4.475 & 20.395 \\
CR_DUMMY & 1233 & .291 & .454 & 0 & 1 \\
RD_DUMMY & 1233 & .368 & .483 & 0 & 1 \\
CAPITAL_INT & 1233 & .055 & .099 & 0 & 1.492 \\
ROA & 1233 & -.02 & .199 & -1.183 & .169 \\
SALES_GROWT & 1233 & .083 & .228 & -.392 & 1 \\
H & 1233 & 1.012 & .141 & .578 & 2.108 \\
MTB & & & & & 109 \\
\hline
\end{tabular}

Note: KZ, WW, and SA indexes are the measures for financial constraints (winsorized at 1\%). Capital intensity, and sales growth are in millions of dollars. Refer to Table 3.1 for detailed definitions of the variables. 
TABLE 3.3: Pearson correlation matrix

\begin{tabular}{|c|c|c|c|c|c|c|c|c|c|c|}
\hline Variables & (1) & (2) & (3) & (4) & (5) & (6) & (7) & (8) & (9) & (10) \\
\hline (1) KZ_INDEX & 1.000 & & & & & & & & & \\
\hline (2) WW_INDEX & $0.081^{* * *}$ & 1.000 & & & & & & & & \\
\hline (3) SA_INDEX & $0.036^{*}$ & $-0.049^{* *}$ & 1.000 & & & & & & & \\
\hline (4) DUAL_CLASS & $0.047^{* *}$ & $0.043^{* *}$ & $-0.040^{* *}$ & 1.000 & & & & & & \\
\hline (5) V_WEDGE & $0.048^{* *}$ & 0.027 & $-0.035^{*}$ & $0.990^{* * * *}$ & 1.000 & & & & & \\
\hline (6) INSIDER_SH & 0.019 & $0.045^{* *}$ & $-0.043^{* *}$ & $0.818^{* * * *}$ & $0.787^{* * *}$ & 1.000 & & & & \\
\hline (7) CAPITAL_INT & $0.055^{* * *}$ & $-0.132^{* * *}$ & -0.017 & 0.014 & 0.019 & $-0.042^{* *}$ & 1.000 & & & \\
\hline (8) $\mathrm{ROA}$ & $-0.160^{* * *}$ & $-0.319^{* * * *}$ & $0.041^{* *}$ & -0.004 & -0.005 & $0.063^{* * *}$ & $-0.118^{* * *}$ & 1.000 & & \\
\hline (9) SALES_GROWTH & -0.020 & $0.168^{* * * *}$ & $-0.124^{* * *}$ & -0.018 & -0.007 & -0.015 & $0.079^{* * * *}$ & $0.040^{* *}$ & 1.000 & \\
\hline (10) MTB & -0.004 & 0.026 & $-0.047^{* *}$ & 0.010 & 0.010 & 0.007 & -0.018 & $-0.057^{* * *}$ & -0.017 & 1.000 \\
\hline
\end{tabular}

$* * *, * *$ and $*$ represent significance levels of $1 \%, 5 \%$ and $10 \%$, respectively 
Table 3.3 presents the correlation results. The KZ_INDEX and WW_INDEX are correlated significantly and positively with the test variable DUAL_CLASS (correlation $=0.047, p<0.05 ;$ correlation $=0.043, p<0.05$, respectively $)$. However, the SA index is correlated significantly and negatively with the test variables DUAL CLASS, V_WEDGE and INSIDER_SH ( correlation $=-0.040$, $p<0.05 ;$ correlation $=-0.035, \quad p<0.10 ;$ correlation $=-0.043, \quad p<0.05$ respectively). DUAL_CLASS is correlated significantly and positively with V_WEDGE $($ correlation $=0.990, p<0.01)$ and with INSIDER_SH $($ correlation $=0.818, p<0.01)$, as these variables are aspects of DUAL_CLASS. It should be noted that the reported correlations are indicative only of bivariate relationships, while the key tests are of the impact of dual-class on financial constraints in a multivariate context.

\subsubsection{Regression Results for the Tests of $\mathrm{H}_{1}, \mathrm{H}_{2}$, And $\mathrm{H}_{3}$}

This section reports and discusses the tests of hypotheses $\mathrm{H}_{1}, \mathrm{H}_{2}$, and $\mathrm{H}_{3}$. The results are given in Tables 3.4, 3.5, and 3.6 where, in each case, the regressions with the KZ, WW, and SA indexes, as measures for financial constraints, are reported in columns 1 to 3 respectively. The regressions include year and industry fixed effects to control for unobservable year and industry characteristics associated with the dual-class share structure and financial constraints, but the coefficients are not reported. To minimize any issues 
concerning heterogeneity and lack of normality, t-values using robust standard errors are calculated. ${ }^{28}$

\section{i. $\quad$ Impact of the Existence of Dual-Class Share Structure $\left(\mathbf{H}_{\mathbf{1}}\right)$}

Table 3.4 shows that the coefficient on DUAL_CLASS is significant and positive, where financial constraints is measured by the $\mathrm{KZ}$ index (coefficient $=$ $3.448 ;$-value $=1.93 ; p<0.1), \mathrm{WW}$ index $($ coefficient $=0.022 ; t$-value $=2.81$; $p<0.01)$ and the SA index $($ coefficient $=0.127 ; t$-value $=2.88 ; p<0.01)$. Thus, the results support $\mathrm{H}_{1}$.

The coefficients on the control variables are mixed. The coefficient on CR_DUMMY is significant and negative (as expected) in the WW regression, but positive and significant in the $\mathrm{KZ}$ and $\mathrm{SA}$ regressions. In the case of the $\mathrm{KZ}$ and WW regressions the coefficients on RD_DUMMY and ROA are consistently significant and negative. However, the SA regression shows the opposite result for RD_DUMMY and ROA. The coefficient on CAPITAL_INT is significant and negative in the WW regression (as expected), but weakly significant and positive in the SA regression. The coefficient on SALES_GROWTH is significant and positive in both the $\mathrm{KZ}$ regression and the SA regression. SALES_GROWTH is not included in the WW regression as sales growth is a component in the computation of the WW index. Finally, the coefficient on MTB is negative but not significant for any of the indexes.

\footnotetext{
${ }^{28}$ Estimating the standard errors using the Huber-White sandwich estimators.
} 
Therefore, overall, there is significant variation in the degree of alignment of control variable coefficients with expectations.

\section{ii. $\quad$ Impact of Voting Divergence $\left(\mathbf{H}_{\mathbf{2}}\right)$}

Table 3.5 shows that the coefficient on V_WEDGE is significant and positive where financial constraints is measured by the KZ index (coefficient $=0.226$; $t$ value $=2.00 ; p<0.05)$, the WW index $($ coefficient $=0.001 ; t$-value $=2.25 ; p$ $<0.05)$, and the SA index (coefficient $=0.012 ; t$-value $=4.20 ; p<0.01)$. Thus, the results support $\mathrm{H}_{2}$.

The coefficients on the control variables are qualitatively similar to the results reported in Table 3.4 .

\section{iii. Impact of the Proximity of Superior Shareholders $\left(\mathbf{H}_{\mathbf{3}}\right)$}

Table 3.6 shows that the coefficient on INSIDER_SH is significant and positive where financial constraints is measured by the WW index (coefficient $=0.027$; $t$-value $=3.80 ; p<0.01)$. However, the coefficient is not significant where financial constraints is measured by the $\mathrm{KZ}$ or $\mathrm{SA}$ indexes. Thus the results support $\mathrm{H}_{3}$, but only where financial constraints are measured by the WW index.

The coefficients on the control variables reported in Table 3.6, are also qualitatively similar to the results reported in Table 3.4. 
Thus, overall, the results support the hypotheses, $\mathrm{H}_{1}, \mathrm{H}_{2}$, and $\mathrm{H}_{3}$ and therefore reinforce the view that dual-class firms are more constrained. However, the results are strongest for voting wedge as a measure of dual-class. 
TABLE 3.4: Results for dual-class share structure on financial constraints (hypothesis 1)

\begin{tabular}{|c|c|c|c|}
\hline FIN_CONS & $\begin{array}{c}\text { KZ_INDEX } \\
\text { Coef. } \\
\text { (t-value) }\end{array}$ & $\begin{array}{c}\text { WW_INDEX } \\
\text { Coef. } \\
\text { (t-value) }\end{array}$ & $\begin{array}{c}\text { SA_INDEX } \\
\text { Coef. } \\
\text { (t-value) }\end{array}$ \\
\hline DUAL_CLASS & $\begin{array}{c}3.448^{*} \\
(1.93)\end{array}$ & $\begin{array}{c}0.022^{* * * *} \\
(2.81)\end{array}$ & $\begin{array}{c}0.127^{* * * *} \\
(2.88)\end{array}$ \\
\hline CR_DUMMY & $\begin{array}{l}8.295^{* * * *} \\
(5.04)\end{array}$ & $\begin{array}{l}-0.080^{* * *} \\
(-9.62)\end{array}$ & $\begin{array}{l}0.920^{* * * *} \\
(19.52)\end{array}$ \\
\hline RD_DUMMY & $\begin{array}{c}-12.928^{* * * *} \\
(-5.20)\end{array}$ & $\begin{array}{c}-0.054^{* * *} \\
(-5.81)\end{array}$ & $\begin{array}{l}0.097^{*} \\
(1.71)\end{array}$ \\
\hline CAPITAL_INT & $\begin{array}{l}6.877 \\
(0.64)\end{array}$ & $\begin{array}{l}-0.271^{* * *} \\
(-6.45)\end{array}$ & $\begin{array}{l}0.551^{*} \\
(1.75)\end{array}$ \\
\hline ROA & $\begin{array}{c}-39.775^{* * *} \\
(-5.62)\end{array}$ & $\begin{array}{l}-0.298^{* * * *} \\
(-10.37)\end{array}$ & $\begin{array}{c}1.097^{* * * *} \\
(6.55)\end{array}$ \\
\hline SALES_GROWTH & $\begin{array}{l}1.432 \\
(0.29)\end{array}$ & - & $\begin{array}{l}0.078 \\
(0.60)\end{array}$ \\
\hline MTB & $\begin{array}{l}-0.343 \\
(-0.07)\end{array}$ & $\begin{array}{l}-0.002 \\
(-0.09)\end{array}$ & $\begin{array}{l}-0.082 \\
(-0.61)\end{array}$ \\
\hline Constant & $\begin{array}{l}5.396 \\
(0.80)\end{array}$ & $\begin{array}{l}-0.313^{* * *} \\
(-5.54)\end{array}$ & $\begin{array}{l}-2.128^{* * *} \\
(-2.86)\end{array}$ \\
\hline $\mathrm{R}^{2}$ & 7.9 & 20.7 & 95.9 \\
\hline $\mathrm{N}$ & 2,466 & 2,466 & 2,466 \\
\hline IND_FE & YES & YES & YES \\
\hline YEAR_FE & YES & YES & YES \\
\hline
\end{tabular}


TABLE 3.5: Results for the impact of voting wedge on financial constraints (hypothesis 2)

\begin{tabular}{|c|c|c|c|}
\hline FIN_CONS & $\begin{array}{c}\text { KZ_INDEX } \\
\text { Coef. } \\
\text { (t-value) }\end{array}$ & $\begin{array}{c}\text { WW_INDEX } \\
\text { Coef. } \\
\text { (t-value) }\end{array}$ & $\begin{array}{c}\text { SA_INDEX } \\
\text { Coef. } \\
\text { (t-value) }\end{array}$ \\
\hline V_WEDGE & $\begin{array}{l}0.226^{* *} \\
(2.00)\end{array}$ & $\begin{array}{c}0.001^{* *} \\
(2.25)\end{array}$ & $\begin{array}{c}0.012^{* * * *} \\
(4.20)\end{array}$ \\
\hline CR_DUMMY & $\begin{array}{l}8.210^{* * * *} \\
(5.00)\end{array}$ & $\begin{array}{c}-0.081^{* * * *} \\
(-9.71)\end{array}$ & $\begin{array}{l}0.917^{* * * *} \\
(19.55)\end{array}$ \\
\hline RD_DUMMY & $\begin{array}{c}-12.969^{* * * *} \\
(-5.22)\end{array}$ & $\begin{array}{c}-0.055^{* * * *} \\
(-5.84)\end{array}$ & $\begin{array}{l}0.095^{*} \\
(1.68)\end{array}$ \\
\hline CAPITAL_INT & $\begin{array}{l}6.817 \\
(0.64)\end{array}$ & $\begin{array}{c}-0.271^{* * *} \\
(-6.46)\end{array}$ & $\begin{array}{l}0.550^{*} \\
(1.77)\end{array}$ \\
\hline ROA & $\begin{array}{c}-39.747^{* * *} \\
(-5.61)\end{array}$ & $\begin{array}{c}-0.298^{* * * *} \\
(-10.38)\end{array}$ & $\begin{array}{c}1.100^{* * * *} \\
(6.58)\end{array}$ \\
\hline SALES_GROWTH & $\begin{array}{l}1.351 \\
(0.27)\end{array}$ & - & $\begin{array}{l}0.077 \\
(0.59)\end{array}$ \\
\hline MTB & $\begin{array}{l}-0.360 \\
(-0.07)\end{array}$ & $\begin{array}{l}-0.002 \\
(-0.09)\end{array}$ & $\begin{array}{l}-0.084 \\
(-0.63)\end{array}$ \\
\hline Constant & $\begin{array}{l}5.461 \\
(0.81)\end{array}$ & $\begin{array}{c}-0.312^{* * * *} \\
(-5.53)\end{array}$ & $\begin{array}{c}-2.130^{* * * *} \\
(-2.86)\end{array}$ \\
\hline $\mathrm{R}^{2}$ & 7.9 & 20.6 & 95.9 \\
\hline $\mathrm{N}$ & 2,466 & 2,466 & 2,466 \\
\hline IND_FE & YES & YES & YES \\
\hline YEAR_FE & YES & YES & YES \\
\hline
\end{tabular}

Table 3.5 shows the OLS regression results for the impact of voting wedge on financial constraints from 2002 to 2018. The test variable is V_WEDGE. Variable definitions are provided in Table 3.1.t-values are shown in parentheses (robust $\mathrm{SE}) . * *, * *$ and $*$ represent significance levels of $1 \%, 5 \%$ and $10 \%$, respectively. 
TABLE 3.6: Results for the impact of the proximity of superior class shareholder on financial constraints (hypothesis 3 )

\begin{tabular}{|c|c|c|c|}
\hline FIN_CONS & $\begin{array}{c}\text { KZ_INDEX } \\
\text { Coef. } \\
\text { (t-value) }\end{array}$ & $\begin{array}{c}\text { WW_INDEX } \\
\text { Coef. } \\
\text { ( t-value })\end{array}$ & $\begin{array}{c}\text { SA_INDEX } \\
\text { Coef. } \\
\text { (t-value) }\end{array}$ \\
\hline INSIDER_SH & $\begin{array}{l}1.963 \\
(1.17)\end{array}$ & $\begin{array}{c}0.027^{* * * *} \\
(3.80)\end{array}$ & $\begin{array}{l}-0.049 \\
(-1.17)\end{array}$ \\
\hline CR_DUMMY & $\begin{array}{l}8.271^{* * * *} \\
(5.02)\end{array}$ & $\begin{array}{c}-0.080^{* * * *} \\
(-9.53)\end{array}$ & $\begin{array}{c}0.913^{* * *} \\
(19.34)\end{array}$ \\
\hline RD_DUMMY & $\begin{array}{c}-12.898^{* * * *} \\
(-5.17)\end{array}$ & $\begin{array}{c}-0.054^{* * * *} \\
(-5.76)\end{array}$ & $\begin{array}{l}0.095^{*} \\
(1.67)\end{array}$ \\
\hline CAPITAL_INT & $\begin{array}{l}7.209 \\
(0.68)\end{array}$ & $\begin{array}{c}-0.265^{* * *} \\
(-6.18)\end{array}$ & $\begin{array}{l}0.537^{*} \\
(1.68)\end{array}$ \\
\hline ROA & $\begin{array}{c}-40.093^{* * *} \\
(-5.70)\end{array}$ & $\begin{array}{c}-0.301^{* * *} \\
(-10.52)\end{array}$ & $\begin{array}{c}1.098^{* * * *} \\
(6.54)\end{array}$ \\
\hline SALES_GROWTH & $\begin{array}{l}1.343 \\
(0.27)\end{array}$ & - & $\begin{array}{l}0.070 \\
(0.53)\end{array}$ \\
\hline MTB & $\begin{array}{l}-0.308 \\
(-0.06)\end{array}$ & $\begin{array}{l}-0.002 \\
(-0.10)\end{array}$ & $\begin{array}{l}-0.077 \\
(-0.58)\end{array}$ \\
\hline Constant & $\begin{array}{l}5.674 \\
(0.84)\end{array}$ & $\begin{array}{c}-0.312^{* * * *} \\
(-5.53)\end{array}$ & $\begin{array}{c}-2.110^{* * * *} \\
(-2.82)\end{array}$ \\
\hline $\mathrm{R}^{2}$ & 7.8 & 20.8 & 95.9 \\
\hline $\mathrm{N}$ & 2,466 & 2,466 & 2,466 \\
\hline IND_FE & YES & YES & YES \\
\hline YEAR_FE & YES & YES & YES \\
\hline
\end{tabular}

Table 3.6 shows the OLS regression results for the impact of the proximity of superior shareholder on financial constraints from 2002 to 2018. The test variable is INSIDER_SH. Variable definitions are provided in Table 3.1. t-values are shown in parentheses (robust SE). ***, ** and * represent significance levels of $1 \%, 5 \%$ and $10 \%$, respectively. 


\subsubsection{Regression Results for the Tests of $\mathrm{H}_{4}, \mathrm{H}_{5}$, and $\mathrm{H}_{6}$}

Table 3.7- Table 3.9 reports the results of the tests of hypotheses $\mathrm{H}_{4}, \mathrm{H}_{5}$, and $\mathrm{H}_{6}$ on the effect of the global financial crisis on the association between dualclass share structures and financial constraints. The impact of the global financial crisis on the association is indicated by the coefficient on the interaction variables DUAL_CLASS*GFC, V_WEDGE*GFC, and INSIDER_SH*GFC in Tables 3.7, 3.8 and 3.9 respectively. There is no significant impact on financial constraints as measured by the $\mathrm{KZ}$ index. In the regressions with financial constraints measured by the WW index, the coefficients on the interaction variables are marginally significant and negative for DUAL_CLASS, V_WEDGE and INSIDER_SH (coefficient $=-0.028 ;$-value $=-1.79 ; p<0.1$; coefficient $=-0.002 ;$-value $=-1.66 ; p<0.1 ;$ and coefficient $=-0.025 ;$-value $=$ -1.66; $p<0.1$; respectively).

Thus, with financial constraints measured by the WW index, there is weak support for the propping theory: that, during the GFC years, existence of dualclass structures had a weaker impact on financial constraints than in other years. This is particularly evident when combining the interaction variable coefficients with the coefficient on the WW index. However, with financial constraints measured by the SA index the coefficient on the interaction variables is significant and positive for DUAL_CLASS and V_WEDGE (coefficient = $0.530 ; t$-value $=2.89 ; p<0.01 ;$ and coefficient $=0.038 ;$-value $=3.34 ; p<$ 0.01; respectively). However, for INSIDER_SH the coefficient is not significant. Thus, in contrast to the results for the WW index, the results for the SA index suggest an increase in constraints during the GFC years and this is 
particularly evident when combining the interaction variable coefficients with the coefficient on the SA index. Overall, the results for the tests of $\mathrm{H}_{4}, \mathrm{H}_{5}$, and $\mathrm{H}_{6}$ can at best be described as mixed. 
TABLE 3.7: Results for the impact of the global financial crisis (hypothesis 4)

\begin{tabular}{|c|c|c|c|}
\hline FIN_CONS & $\begin{array}{c}\text { KZ_INDEX } \\
\text { Coef. } \\
\text { (t-value) }\end{array}$ & $\begin{array}{c}\text { WW_INDEX } \\
\text { Coef. } \\
\text { ( t-value) }\end{array}$ & $\begin{array}{c}\text { SA_INDEX } \\
\text { Coef. } \\
\text { (t-value) }\end{array}$ \\
\hline DUAL_CLASS & $\begin{array}{l}2.329 \\
(1.11)\end{array}$ & $\begin{array}{c}0.027^{* * * *} \\
(3.07)\end{array}$ & $\begin{array}{c}0.027^{* * *} \\
(0.86)\end{array}$ \\
\hline GFC & $\begin{array}{l}-4.349 \\
(-1.47)\end{array}$ & $\begin{array}{l}0.078^{* *} \\
(2.56)\end{array}$ & $\begin{array}{c}18.744^{* * *} \\
(67.85)\end{array}$ \\
\hline DUAL_CLASS*GFC & $\begin{array}{l}5.956 \\
(1.64)\end{array}$ & $\begin{array}{l}-0.028^{*} \\
(-1.79)\end{array}$ & $\begin{array}{l}0.530^{* * * *} \\
(2.89)\end{array}$ \\
\hline CR_DUMMY & $\begin{array}{c}8.251^{* * *} \\
(5.02)\end{array}$ & $\begin{array}{c}-0.080^{* * * *} \\
(-9.58)\end{array}$ & $\begin{array}{l}0.916^{* * *} \\
(19.56)\end{array}$ \\
\hline RD_DUMMY & $\begin{array}{c}-12.901^{* * *} \\
(-5.19)\end{array}$ & $\begin{array}{c}-0.055^{* * * *} \\
(-5.82)\end{array}$ & $\begin{array}{l}0.099^{*} \\
(1.76)\end{array}$ \\
\hline CAPITAL_INT & $\begin{array}{l}7.092 \\
(0.66)\end{array}$ & $\begin{array}{c}-0.272^{* * *} \\
(-6.51)\end{array}$ & $\begin{array}{l}0.570^{*} \\
(1.79)\end{array}$ \\
\hline ROA & $\begin{array}{c}-39.711^{* * *} \\
(-5.63)\end{array}$ & $\begin{array}{c}-0.298^{* * * *} \\
(-10.38)\end{array}$ & $\begin{array}{l}1.103^{* * * *} \\
(6.70)\end{array}$ \\
\hline SALES_GROWTH & $\begin{array}{l}1.542 \\
(0.31)\end{array}$ & - & $\begin{array}{l}0.088 \\
(0.69)\end{array}$ \\
\hline MTB & $\begin{array}{l}-0.092 \\
(-0.02)\end{array}$ & $\begin{array}{l}-0.003 \\
(-0.14)\end{array}$ & $\begin{array}{l}-0.060 \\
(-0.44)\end{array}$ \\
\hline Constant & $\begin{array}{l}5.811 \\
(0.89)\end{array}$ & $\begin{array}{c}-0.315^{* * * *} \\
(-5.47)\end{array}$ & $\begin{array}{c}-2.091^{* * *} \\
(-2.64)\end{array}$ \\
\hline $\mathrm{R}^{2}$ & 8.0 & 20.7 & 95.9 \\
\hline $\mathrm{N}$ & 2,466 & 2,466 & 2,466 \\
\hline $\begin{array}{l}\text { IND_FE } \\
\text { YEAR_FE }\end{array}$ & $\begin{array}{l}\text { YES } \\
\text { YES }\end{array}$ & $\begin{array}{l}\text { YES } \\
\text { YES }\end{array}$ & $\begin{array}{l}\text { YES } \\
\text { YES }\end{array}$ \\
\hline
\end{tabular}

Table 3.7 shows the OLS regression results for the impact of the global financial crisis on the relationship between dualclass share structure and financial constraints from 2002 to 2018. The test variable is DUAL-CLASS. Variable definitions are provided in Table 3.1. t-values are shown in parentheses (robust SE). ***, ** and * represent significance levels of $1 \%, 5 \%$ and $10 \%$, respectively. 
TABLE 3.8: Results for the impact of the global financial crisis (hypothesis 5)

\begin{tabular}{|c|c|c|c|}
\hline FIN_CONS & $\begin{array}{c}\text { KZ_INDEX } \\
\text { Coef. } \\
\text { (t-value) }\end{array}$ & $\begin{array}{c}\text { WW_INDEX } \\
\text { Coef. } \\
\text { ( t-value) }\end{array}$ & $\begin{array}{c}\text { SA_INDEX } \\
\text { Coef. } \\
\text { (t-value) }\end{array}$ \\
\hline V_WEDGE & $\begin{array}{l}0.157 \\
(1.19)\end{array}$ & $\begin{array}{c}0.001^{* *} \\
(2.53)\end{array}$ & $\begin{array}{c}0.005^{* * *} \\
(2.25)\end{array}$ \\
\hline GFC & $\begin{array}{l}-4.299 \\
(-1.45)\end{array}$ & $\begin{array}{c}0.077^{* * *} \\
(2.51)\end{array}$ & $\begin{array}{c}18.726^{* * * *} \\
(67.93)\end{array}$ \\
\hline V_WEDGE* GFC & $\begin{array}{l}0.374 \\
(1.62)\end{array}$ & $\begin{array}{l}-0.002^{*} \\
(-1.66)\end{array}$ & $\begin{array}{c}0.038^{* * *} \\
(3.34)\end{array}$ \\
\hline CR_DUMMY & $\begin{array}{c}8.148^{* * *} \\
(4.97)\end{array}$ & $\begin{array}{c}-0.080^{* * * *} \\
(-9.67)\end{array}$ & $\begin{array}{l}0.911^{\text {**** }} \\
(19.57)\end{array}$ \\
\hline RD_DUMMY & $\begin{array}{c}-12.933^{* * *} \\
(-5.21)\end{array}$ & $\begin{array}{c}-0.055^{* * *} \\
(-5.86)\end{array}$ & $\begin{array}{l}0.198^{*} \\
(1.76)\end{array}$ \\
\hline CAPITAL_INT & $\begin{array}{l}7.020 \\
(0.66)\end{array}$ & $\begin{array}{c}-0.272^{* * * *} \\
(-6.52)\end{array}$ & $\begin{array}{l}0.570^{*} \\
(1.80)\end{array}$ \\
\hline ROA & $\begin{array}{c}-39.680^{* * * *} \\
(-5.62)\end{array}$ & $\begin{array}{c}-0.298^{* * *} \\
(-10.39)\end{array}$ & $\begin{array}{c}1.107^{* * * *} \\
(6.76)\end{array}$ \\
\hline SALES_GROWTH & $\begin{array}{l}1.430 \\
(0.29)\end{array}$ & - & $\begin{array}{l}0.085 \\
(0.66)\end{array}$ \\
\hline MTB & $\begin{array}{l}-0.093 \\
(-0.02)\end{array}$ & $\begin{array}{l}-0.003 \\
(-0.14)\end{array}$ & $\begin{array}{l}-0.057 \\
(-0.42)\end{array}$ \\
\hline Constant & $\begin{array}{l}5.879 \\
(0.90)\end{array}$ & $\begin{array}{c}-0.314^{* * *} \\
(-5.46)\end{array}$ & $\begin{array}{c}-2.088^{* * *} \\
(-2.62)\end{array}$ \\
\hline $\mathrm{R}^{2}$ & 8.0 & 20.6 & 96.0 \\
\hline $\mathrm{N}$ & 2,466 & 2,466 & 2,466 \\
\hline IND_FE & YES & YES & YES \\
\hline YEAR_FE & YES & YES & YES \\
\hline
\end{tabular}

Table 3.8 shows the OLS regression results for the impact of the global financial crisis on the relationship between voting wedge and financial constraints from 2002 to 2018. The test variable is V_WEDGE. Variable definitions are provided in Table 3.1.t-values are shown in parentheses (robust SE). $* * * * *$ and $*$ represent significance levels of $1 \%, 5 \%$ and $10 \%$, respectively. 
TABLE 3.9: Results for the impact of global financial crisis (hypothesis 6)

\begin{tabular}{|c|c|c|c|}
\hline FIN_CONS & $\begin{array}{c}\text { KZ_INDEX } \\
\text { Coef. } \\
\text { ( } \mathrm{t} \text {-value) }\end{array}$ & $\begin{array}{c}\text { WW_INDEX } \\
\text { Coef. } \\
\text { (t-value) }\end{array}$ & $\begin{array}{l}\text { SA_INDEX } \\
\text { Coef. } \\
\text { (t-value) }\end{array}$ \\
\hline INSIDER_SH & $\begin{array}{l}1.562 \\
(0.80)\end{array}$ & $\begin{array}{c}0.031^{* * *} \\
(3.91)\end{array}$ & $\begin{array}{c}-0.088^{* * *} \\
(-2.76)\end{array}$ \\
\hline GFC & $\begin{array}{l}-2.931 \\
(-1.10)\end{array}$ & $\begin{array}{l}0.074^{* *} \\
(2.45)\end{array}$ & $\begin{array}{c}18.871^{* * *} \\
(69.31)\end{array}$ \\
\hline INSIDER_SH $*$ GFC & $\begin{array}{l}2.219 \\
(0.68)\end{array}$ & $\begin{array}{l}-0.025^{*} \\
(-1.66)\end{array}$ & $\begin{array}{l}0.220 \\
(1.21)\end{array}$ \\
\hline CR_DUMMY & $\begin{array}{c}8.280^{* * * *} \\
(5.02)\end{array}$ & $\begin{array}{c}-0.080^{* * * *} \\
(-9.54)\end{array}$ & $\begin{array}{l}0.914^{* * * *} \\
(19.35)\end{array}$ \\
\hline RD_DUMMY & $\begin{array}{c}-12.886^{* * * *} \\
(-5.17)\end{array}$ & $\begin{array}{c}-0.054^{* * * *} \\
(-5.78)\end{array}$ & $\begin{array}{l}0.096^{*} \\
(1.70)\end{array}$ \\
\hline CAPITAL_INT & $\begin{array}{l}7.161 \\
(0.67)\end{array}$ & $\begin{array}{c}-0.265^{* * *} \\
(-6.17)\end{array}$ & $\begin{array}{l}0.532^{*} \\
(1.66)\end{array}$ \\
\hline ROA & $\begin{array}{c}-40.022^{* * *} \\
(-5.69)\end{array}$ & $\begin{array}{c}-0.302^{* * * *} \\
(-10.55)\end{array}$ & $\begin{array}{l}1.105^{* * *} \\
(6.59)\end{array}$ \\
\hline SALES_GROWTH & $\begin{array}{l}1.383 \\
(0.28)\end{array}$ & - & $\begin{array}{l}0.074 \\
(0.56)\end{array}$ \\
\hline МТВ & $\begin{array}{l}-0.256 \\
(-0.05)\end{array}$ & $\begin{array}{l}-0.003 \\
(-0.12)\end{array}$ & $\begin{array}{l}-0.072 \\
(-0.54)\end{array}$ \\
\hline Constant & $\begin{array}{l}5.797 \\
(0.87)\end{array}$ & $\begin{array}{c}-0.314^{* * * *} \\
(-5.48)\end{array}$ & $\begin{array}{c}-2.098^{* * *} \\
(-2.75)\end{array}$ \\
\hline $\mathrm{R}^{2}$ & 7.8 & 20.9 & 95.9 \\
\hline $\mathrm{N}$ & 2,466 & 2,466 & 2,466 \\
\hline IND_FE & YES & YES & YES \\
\hline YEAR_FE & YES & YES & YES \\
\hline
\end{tabular}

Table 3.9 shows the OLS regression results for the impact of the global financial crisis on the relationship between the proximity of superior shareholder and financial constraints from 2002 to 2018. The test variable is INSIDER_SH. Variable definitions are provided in Table 3.1. t-values are shown in parentheses (robust SE). ***,** and * represent significance levels of $1 \%, 5 \%$ and $10 \%$, respectively. 


\subsubsection{Additional Tests}

As additional tests for the impact of dual-class share structures on financial constraints, the HM index as a measure of financial constraints is used and the effect of firm age as moderating effect of dual-class on financial constraints is tested. Hypotheses 1-6 are also tested using the BLM index as the measure of financial constraints.

\subsubsection{HM Index as a Measure of Financial Constraints}

The Hoberg and Maksimovic (2014) text based index (the HM Index) is used to examine the different dimensions of access to finance: in particular, whether dual-class firms are more liquidity constrained, equity constrained, or debt constrained. The authors consider that the use of words such as 'delay,' 'abandon,' 'curtail' and 'construction,' in the 10-K Liquidity and Capital Resources subsection of the Management Discussion and Analysis section, indicates the presence of financial constraints. In this particular subsection, firms disclose their concerns regarding financial liquidity and the firm's intention regarding access to the capital market. This section is context-sensitive. When managers indicate the possible need to delay investment, the potential investor's intended conclusion is that the firm is investing less than what might be optimal owing to challenges to its liquidity.

Hoberg and Maksimovic (2014) argue that the earlier measures of financial constraints are unidimensional, and do not distinguish between the different types of constraint situations, such as equity-focused, debt-focused or private 
placement focused constraints. ${ }^{29}$ They argue that equity, debt, and private placement focused constraints have unique characteristics, and these may not be identified systematically using overall firm financial characteristics. The authors, thus, construct four scores based on four different dimensions for each firm, which are "Delay Investment Score" (D_INV_SC), "Equity Focus Delay Investment Score" (E_D_INV_SC) "Debt Focus Delay Investment Score" (D_D_INV_SC), and the "Private Placement Focus Delay Investment Score" (PP_INV_SC). The authors score the delayed investment by the average vocabulary (the list of words mentioned above) used by firms while controlling for the presence of standard text. The authors use the percentage of these words to measure the degree of financial constraint.

Data on the index is available from the Hoberg and Maksimovic's website ${ }^{30}$ but has been developed only to $2015 .{ }^{31}$ Thus, as noted at footnote above, the dataset for the HM tests was constructed by following the procedure described in Table 3.2, Panel A, but with the HM index replacing the other indexes. The procedure yielded 45,126 firm-year observations which, after application of the STATA PSM procedure, resulted in a sample of 2,290 firm-year observations comprising 1,145 observations on dual-class firms and 1,145 matching observations.

\footnotetext{
${ }^{29}$ According to the authors, existing constraint measures are built on comparatively small samples using accounting ratios, and then applied to different populations of firms. Therefore they do not represents the financial constraint situation properly.

${ }^{30}$ Data source: http://www-bcf.usc.edu/ hoberg/MaxDataSite/index.html

31 The mean of D_INV_SC, E_D_INV_SC, D_D_INV_SC, and PP_INV_SC are $1.966,-2.40,1.03$, and -1.84 respectively. D_INV_SC is correlated positively and strongly with E_D_INV_SC and correlated negatively with D_D_INV_SC. As expected, E_D_INV_SC is correlated positively and strongly with PP_D_INV_SC (both represent equity constraints).
} 
Tables 3.10, 3.11, and 3.12 report the results of tests of the impact of dual-class share structure on financial constraints as measured by each of the four HM index scores. The regression results are based on the sample of 2,290 firm-year observations over the period 2002-2015.

The results in columns 1- 4 of Table 3.10 show that dual-class has a significant and positive impact on financial constraints as measured by the debt score D_D_INV_SC $($ coefficient $=0.563 ; t$-value $=2.46 ; p<0.05)$, but there is no significant impact on financial constraints when measured by the other scores. Table 3.11 reports similar results for V_WEDGE $($ coefficient $=0.031$; $t$-value $=$ 2.15; $p$ <0.05). Likewise for INSIDER_SH in Table 3.12, D_D_INV_SC (coefficient $=0.405 ;$-value $=1.72 ; p<0.1)$ is significant and positive.

The results, thus, suggest that dual-class firms are more constrained in respect of access to debt. A possible interpretation of the results is that dual-class firms could have higher cost of debt owing to agency conflict between shareholders, which generates debt-focused constraints. In line with Hoberg and Maksimovic (2014), it is assumed that a high existing debt burden could be a material factor regarding debt market constraints and debt constrained firms find it difficult to fund their investment opportunities because of excess liabilities. This raises a red 
flag for dual-class firms as, according to Hoberg and Maksimovic (2014) ${ }^{32}$, debtconstrained firms usually struggle to meet their contractual obligations.

32 This is in line with the finding of Hoberg and Maksimovic (2014) that, debt-focused constrained firms have higher leverage, and they are positively related to the covenant violation. 
TABLE 3.10: Results for the association between the dual-class share structure and financial constraints using HM Index (hypothesis 1)

\begin{tabular}{|c|c|c|c|c|}
\hline HM_INDEX & $\begin{array}{c}\text { D_INV_SC } \\
\text { Coef. } \\
\text { ( t-value) }\end{array}$ & $\begin{array}{c}\text { E_D_INV_SC } \\
\text { Coef. } \\
\text { ( t-value })\end{array}$ & $\begin{array}{c}\text { D_D_INV_SC } \\
\text { Coef. } \\
\text { ( t-value) }\end{array}$ & $\begin{array}{c}\text { PP_D_INV_SC } \\
\text { Coef. } \\
\text { (t-value })\end{array}$ \\
\hline DUAL_CLASS & $\begin{array}{l}-0.451 \\
(-1.20)\end{array}$ & $\begin{array}{l}-0.177 \\
(-0.52)\end{array}$ & $\begin{array}{c}0.563^{* *} \\
(2.46)\end{array}$ & $\begin{array}{l}-0.196 \\
(-0.64)\end{array}$ \\
\hline CR_DUMMY & $\begin{array}{c}2.306^{* * * *} \\
(5.46)\end{array}$ & $\begin{array}{c}1.062^{* * * *} \\
(2.83)\end{array}$ & $\begin{array}{c}1.993^{* * * *} \\
(7.92)\end{array}$ & $\begin{array}{c}-1.087^{* * *} \\
(-3.30)\end{array}$ \\
\hline RD_DUMMY & $\begin{array}{l}0.942^{* *} \\
(2.09)\end{array}$ & $\begin{array}{c}1.390^{* * *} \\
(3.40)\end{array}$ & $\begin{array}{c}-2.689^{* * * *} \\
(-9.42)\end{array}$ & $\begin{array}{l}2.455^{* * * *} \\
(6.52)\end{array}$ \\
\hline CAPITAL_INT & $\begin{array}{l}7.227^{* * * *} \\
(2.61)\end{array}$ & $\begin{array}{l}6.174^{* *} \\
(2.41)\end{array}$ & $\begin{array}{l}-2.915^{* *} \\
(-2.31)\end{array}$ & $\begin{array}{c}6.356^{* * *} \\
(3.31)\end{array}$ \\
\hline ROA & $\begin{array}{c}-8.038^{* * *} \\
(-5.10)\end{array}$ & $\begin{array}{c}-12.493^{* * * *} \\
(-8.03)\end{array}$ & $\begin{array}{l}1.012 \\
(1.15)\end{array}$ & $\begin{array}{c}-11.764^{* * *} \\
(-8.32)\end{array}$ \\
\hline SALES_GROWTH & $\begin{array}{l}4.450^{* * * *} \\
(3.95)\end{array}$ & $\begin{array}{l}5.516^{* * * *} \\
(5.07)\end{array}$ & $\begin{array}{l}-0.169 \\
(-0.26)\end{array}$ & $\begin{array}{c}4.651^{* * * *} \\
(5.00)\end{array}$ \\
\hline MTB & $\begin{array}{l}1.007 \\
(1.02)\end{array}$ & $\begin{array}{l}1.713^{*} \\
(1.69)\end{array}$ & $\begin{array}{l}0.798 \\
(1.33)\end{array}$ & $\begin{array}{l}0.661 \\
(0.58)\end{array}$ \\
\hline Constant & $\begin{array}{c}-12.122^{* * *} \\
(-6.54)\end{array}$ & $\begin{array}{c}-14.965^{* * *} \\
(-9.17)\end{array}$ & $\begin{array}{l}5.954^{*} \\
(1.89)\end{array}$ & $\begin{array}{c}-16.930^{* * *} \\
(-11.66)\end{array}$ \\
\hline $\mathrm{R}^{2}$ & 6.7 & 8.1 & 10.9 & 10.8 \\
\hline $\mathrm{N}$ & 2,290 & 2,290 & 2,290 & 2,290 \\
\hline IND_FE & YES & YES & YES & YES \\
\hline YEAR_FE & YES & YES & YES & YES \\
\hline
\end{tabular}

Table 3.10 shows the OLS regression results for the association between the dual-class share structure and financial constraints from 2002 to 2015. Dependent variable is financial constraints (HM-INDEX) and the test variable is DUAL_CLASS. Variable definitions are provided in the Table 3.1. t-values are shown in parentheses(robust SE). $* * *, * *$ and $*$ represent significance levels of $1 \%, 5 \%$ and $10 \%$, respectively. 
TABLE 3.11: Results for the association between the voting wedge and financial constraints using HM Index (hypothesis 2)

\begin{tabular}{|c|c|c|c|c|}
\hline HM_INDEX & $\begin{array}{c}\text { D_INV_SC } \\
\text { Coef. } \\
\text { ( t-value) }\end{array}$ & $\begin{array}{c}\text { E_D_INV_SC } \\
\text { Coef. } \\
\text { ( t-value) }\end{array}$ & $\begin{array}{c}\text { D_D_INV_SC } \\
\text { Coef. } \\
\text { ( t-value) }\end{array}$ & $\begin{array}{c}\text { PP_D_INV_SC } \\
\text { Coef. } \\
\text { (t-value })\end{array}$ \\
\hline V_WEDGE & $\begin{array}{l}-0.012 \\
(-0.52)\end{array}$ & $\begin{array}{l}0.006 \\
(0.28)\end{array}$ & $\begin{array}{c}0.031^{* *} \\
(2.15)\end{array}$ & $\begin{array}{l}0.005 \\
(0.26)\end{array}$ \\
\hline CR_DUMMY & $\begin{array}{c}2.330^{* * *} \\
(5.54)\end{array}$ & $\begin{array}{c}1.079^{* * *} \\
(2.88)\end{array}$ & $\begin{array}{c}1.974^{* * *} \\
(7.85)\end{array}$ & $\begin{array}{c}-1.070^{* * *} \\
(-3.25)\end{array}$ \\
\hline RD_DUMMY & $\begin{array}{c}0.964^{* *} \\
(2.14)\end{array}$ & $\begin{array}{c}1.411^{* * *} \\
(3.45)\end{array}$ & $\begin{array}{c}-2.697^{\text {*** }} \\
(-9.45)\end{array}$ & $\begin{array}{c}2.476^{* * *} \\
(6.57)\end{array}$ \\
\hline CAPITAL_INT & $\begin{array}{c}7.333^{* * * *} \\
(2.64)\end{array}$ & $\begin{array}{c}6.269^{* *} \\
(2.44)\end{array}$ & $\begin{array}{c}-2.972^{* *} \\
(-2.36)\end{array}$ & $\begin{array}{c}6.453^{* * *} \\
(3.35)\end{array}$ \\
\hline ROA & $\begin{array}{c}-8.054^{* * *} \\
(-5.10)\end{array}$ & $\begin{array}{c}-12.493^{* * *} \\
(-8.03)\end{array}$ & $\begin{array}{l}1.041 \\
(1.18)\end{array}$ & $\begin{array}{c}-11.765^{* * *} \\
(-8.32)\end{array}$ \\
\hline SALES_GROWTH & $\begin{array}{c}4.467^{* * *} \\
(3.96)\end{array}$ & $\begin{array}{c}5.524^{* * * *} \\
(5.08)\end{array}$ & $\begin{array}{l}-0.188 \\
(-0.29)\end{array}$ & $\begin{array}{c}4.660^{* * *} \\
(5.01)\end{array}$ \\
\hline MTB & $\begin{array}{l}1.017 \\
(1.03)\end{array}$ & $\begin{array}{l}1.725^{*} \\
(1.70)\end{array}$ & $\begin{array}{l}0.798 \\
(1.33)\end{array}$ & $\begin{array}{l}0.673 \\
(0.59)\end{array}$ \\
\hline Constant & $\begin{array}{c}-12.420^{* * * *} \\
(-6.73)\end{array}$ & $\begin{array}{c}-15.241^{* * *} \\
(-9.39)\end{array}$ & $\begin{array}{l}6.095^{*} \\
(1.94)\end{array}$ & $\begin{array}{c}-17.209^{* * *} \\
(-11.94)\end{array}$ \\
\hline $\mathrm{R}^{2}$ & 6.6 & 8.1 & 10.8 & 10.8 \\
\hline $\mathrm{N}$ & 2,290 & 2,290 & 2,290 & 2,290 \\
\hline IND_FE & YES & YES & YES & YES \\
\hline YEAR_FE & YES & YES & YES & YES \\
\hline
\end{tabular}

Table 3.11 the OLS regression results for the association between voting wedge and financial constraints from 2002 to 2015 . Dependent variable is financial constraints (HM-INDEX) and the test variable is V_WEDGE. Variable definitions are provided in the Table 3.1. $\mathrm{t}$-values are shown in parentheses(robust SE). $* * *, * *$ and $*$ represent significance levels of $1 \%, 5 \%$ and $10 \%$, respectively. 
TABLE 3.12: Results for the association between the proximity of superior-class shareholder and financial constraints using HM Index (hypothesis 3)

\begin{tabular}{|c|c|c|c|c|}
\hline HM_INDEX & $\begin{array}{c}\text { D_INV_SC } \\
\text { Coef. } \\
\text { ( t-value) }\end{array}$ & $\begin{array}{c}\text { E_D_INV_SC } \\
\text { Coef. } \\
\text { ( t-value) }\end{array}$ & $\begin{array}{c}\text { D_D_INV_SC } \\
\text { Coef. } \\
\text { (t-value) }\end{array}$ & $\begin{array}{c}\text { PP_D_INV_SC } \\
\text { Coef. } \\
\text { (t-value) }\end{array}$ \\
\hline INSIDER_SH & $\begin{array}{l}0.053 \\
(0.14)\end{array}$ & $\begin{array}{l}-0.091 \\
(-0.27)\end{array}$ & $\begin{array}{l}0.405^{*} \\
(1.72)\end{array}$ & $\begin{array}{l}-0.407 \\
(-1.31)\end{array}$ \\
\hline CR_DUMMY & $\begin{array}{c}2.343^{* * * *} \\
(5.54)\end{array}$ & $\begin{array}{c}1.067^{* * *} \\
(2.83)\end{array}$ & $\begin{array}{c}1.989^{* * *} \\
(7.88)\end{array}$ & $\begin{array}{c}-1.109^{* * *} \\
(-3.35)\end{array}$ \\
\hline RD_DUMMY & $\begin{array}{c}0.982^{* *} \\
(2.17)\end{array}$ & $\begin{array}{c}1.396^{* * * *} \\
(3.41)\end{array}$ & $\begin{array}{c}-2.699^{* * *} \\
(-9.46)\end{array}$ & $\begin{array}{c}2.435^{* * *} \\
(6.47)\end{array}$ \\
\hline CAPITAL_INT & $\begin{array}{c}7.426^{* * * *} \\
(2.65)\end{array}$ & $\begin{array}{l}6.182^{* *} \\
(2.40)\end{array}$ & $\begin{array}{c}-2.867^{* *} \\
(-2.27)\end{array}$ & $\begin{array}{c}6.172^{* * * *} \\
(3.19)\end{array}$ \\
\hline ROA & $\begin{array}{c}-8.057^{* * *} \\
(-5.08)\end{array}$ & $\begin{array}{c}-12.478^{* * * *} \\
(-8.01)\end{array}$ & $\begin{array}{c}0.944 \\
(1.07)\end{array}$ & $\begin{array}{c}-11.689^{* * *} \\
(-8.27)\end{array}$ \\
\hline SALES_GROWTH & $\begin{array}{c}4.474^{* * * *} \\
(3.96)\end{array}$ & $\begin{array}{c}5.514^{* * * *} \\
(5.07)\end{array}$ & $\begin{array}{l}-0.150 \\
(-0.23)\end{array}$ & $\begin{array}{c}4.617^{\text {**** }} \\
(4.96)\end{array}$ \\
\hline MTB & $\begin{array}{l}1.027 \\
(1.04)\end{array}$ & $\begin{array}{l}1.718^{*} \\
(1.70)\end{array}$ & $\begin{array}{l}0.785 \\
(1.31)\end{array}$ & $\begin{array}{l}0.659 \\
(0.58)\end{array}$ \\
\hline Constant & $\begin{array}{c}-12.657^{* * * *} \\
(-6.80)\end{array}$ & $\begin{array}{c}-15.054^{* * *} \\
(-9.21)\end{array}$ & $\begin{array}{l}6.110^{*} \\
(1.94)\end{array}$ & $\begin{array}{c}-16.696^{* * * *} \\
(-11.57)\end{array}$ \\
\hline $\mathrm{R}^{2}$ & 6.6 & 8.1 & 10.7 & 10.9 \\
\hline $\mathrm{N}$ & 2,290 & 2,290 & 2,290 & 2,290 \\
\hline IND_FE & YES & YES & YES & YES \\
\hline YEAR_FE & YES & YES & YES & YES \\
\hline
\end{tabular}

Table 3.12 shows the OLS regression results for the association between the proximity of superior shareholder and financial constraints from 2002 to 2015. Dependent variable is financial constraints (HM-INDEX) and the test variable is INSIDER_SH. Variable definitions are provided in the Table 3.1. t-values are shown in parentheses (robust SE). $* * * * *$ and $*$ represent significance levels of $1 \%, 5 \%$ and $10 \%$, respectively. 


\subsubsection{Moderating Impact of Firm Age}

Some firms have a perpetual dual-class structure, while other firms adopt sunset provisions ${ }^{33}$. Bebchuk and Kastiel (2017) argue that dual-class firms agency cost tend to increase over time and, thus, performance declines with firms' age. Therefore, it is appropriate to analyse the moderating effect of firm age, $\mathrm{AGE}^{34}$, on the impact of dual-class share structure on financial constraints.

Tables 3.13-3.15 report the results of tests for the moderating effect of age as indicated by the coefficient on the interaction variables: DUAL_CLASS*AGE, V_WEDGE*AGE, and INSIDER_SH*AGE. The coefficients on DUAL_CLASS*AGE, V_WEDGE*AGE and INSIDER_SH are not significant for the $\mathrm{KZ}$ index as the measure of financial constraints. However, the coefficients on DUAL_CLASS*AGE, V_WEDGE*AGE and INSIDER_SH are significant and positive where the WW index is the measure of financial constraints $($ coefficient $=0.002 ; t$-value $=2.66 ; p<0.01 ;$ coefficient $=0.000 ; t$ value $=2.35 ; p<0.05 ;$ and coefficient $=0.002 ; t$-value $=3.00 ; p<0.01 ;$ respectively).

The evidence thus points to at a moderating impact of age on the association between dual-class share structure and financial constraints and supports

\footnotetext{
${ }^{33}$ Sunset provision allows the superior class shareholders to convert to single class share structure (one share one vote) after a certain period.

${ }^{34}$ AGE refers to the years a firm is listed on COMPUSTAT.
} 
Bebchuk and Kastiel (2017)'s findings where financial constraints are measured by the WW index. The regression for the effect of age is not tested where financial constraints are measured by the SA index, as age is included in the calculation of the index. 
TABLE 3.13: Results for the moderating impact of firm age

\begin{tabular}{|c|c|c|}
\hline FIN_CONS & $\begin{array}{c}\text { KZ_INDEX } \\
\text { Coef. } \\
\text { (t-value) }\end{array}$ & $\begin{array}{c}\text { WW_INDEX } \\
\text { Coef. } \\
\text { (t-value })\end{array}$ \\
\hline DUAL_CLASS & $\begin{array}{l}\text { 7.613* } \\
(1.70)\end{array}$ & $\begin{array}{l}-0.011 \\
(-0.64)\end{array}$ \\
\hline AGE & $\begin{array}{l}0.299^{* *} \\
(2.22)\end{array}$ & $\begin{array}{c}-0.001^{* * *} \\
(-3.09)\end{array}$ \\
\hline $\begin{array}{l}\text { DUAL_CLASS } \\
\text { *AGE }\end{array}$ & $\begin{array}{l}-0.213 \\
(-1.26)\end{array}$ & $\begin{array}{c}0.002^{* * *} \\
(2.66)\end{array}$ \\
\hline CR_DUMMY & $\begin{array}{c}7.161^{* * * *} \\
(4.51)\end{array}$ & $\begin{array}{c}-0.075^{* * *} \\
(-9.19)\end{array}$ \\
\hline RD_DUMMY & $\begin{array}{c}-12.734^{* * *} \\
(-5.12)\end{array}$ & $\begin{array}{c}-0.055^{* * *} \\
(-5.84)\end{array}$ \\
\hline CAPITAL_INT & $\begin{array}{l}6.934 \\
(0.65)\end{array}$ & $\begin{array}{c}-0.269^{* * *} \\
(-6.58)\end{array}$ \\
\hline ROA & $\begin{array}{c}-41.504^{* * * *} \\
(-5.81)\end{array}$ & $\begin{array}{c}-0.291^{* * *} \\
(-10.36)\end{array}$ \\
\hline SALES_GROWTH & $\begin{array}{l}3.158 \\
(0.62)\end{array}$ & - \\
\hline MTB & $\begin{array}{l}-0.357 \\
(-0.07)\end{array}$ & $\begin{array}{l}-0.001 \\
(-0.07)\end{array}$ \\
\hline Constant & $\begin{array}{l}-0.296 \\
(-0.04)\end{array}$ & $\begin{array}{c}-0.290^{* * * *} \\
(-5.42)\end{array}$ \\
\hline $\mathrm{R}^{2}(\%)$ & 8.2 & 21.0 \\
\hline $\mathrm{N}$ & 2,466 & 2,466 \\
\hline IND_FE & YES & YES \\
\hline YEAR_FE & YES & YES \\
\hline
\end{tabular}

Table 3.13 shows the OLS regression results for the moderating impact of firm age on the relationship between dual-class share structure and financial constraints from 2002 to 2018. The test variable is DUAL-CLASS. Variable definitions are provided in Table 3.1. t-values are shown in parentheses (robust SE). ***,** and * represent significance levels of $1 \%, 5 \%$ and $10 \%$, respectively. 
TABLE 3.14: Results for the moderating impact of firm age

\begin{tabular}{|c|c|c|}
\hline FIN_CONS & $\begin{array}{c}\text { KZ_INDEX } \\
\text { Coef. } \\
\text { ( t-value })\end{array}$ & $\begin{array}{c}\text { WW_INDEX } \\
\text { Coef. } \\
\text { ( t-value })\end{array}$ \\
\hline V_WEDGE & $\begin{array}{l}0.505^{*} \\
(1.84)\end{array}$ & $\begin{array}{l}-0.001 \\
(-0.66)\end{array}$ \\
\hline AGE & $\begin{array}{l}0.308^{* *} \\
(2.32)\end{array}$ & $\begin{array}{c}-0.001^{* * *} \\
(-2.84)\end{array}$ \\
\hline V_WEDGE $*$ AGE & $\begin{array}{l}-0.014 \\
(-1.37)\end{array}$ & $\begin{array}{l}0.000^{* *} \\
(2.35)\end{array}$ \\
\hline CR_DUMMY & $\begin{array}{c}7.105^{* * *} \\
(4.48)\end{array}$ & $\begin{array}{c}-0.076^{* * *} \\
(-9.37)\end{array}$ \\
\hline RD_DUMMY & $\begin{array}{c}-12.798^{* * * *} \\
(-5.16)\end{array}$ & $\begin{array}{c}-0.055^{* * *} \\
(-5.86)\end{array}$ \\
\hline CAPITAL_INT & $\begin{array}{l}6.852 \\
(0.64)\end{array}$ & $\begin{array}{c}-0.270^{* * *} \\
(-6.59)\end{array}$ \\
\hline ROA & $\begin{array}{c}-41.557^{* * * *} \\
(-5.82)\end{array}$ & $\begin{array}{c}-0.291^{* * *} \\
(-10.37)\end{array}$ \\
\hline SALES_GROWTH & $\begin{array}{l}3.109 \\
(0.61)\end{array}$ & - \\
\hline MTB & $\begin{array}{l}-0.378 \\
(-0.08)\end{array}$ & $\begin{array}{c}0.001 \\
(-0.07)\end{array}$ \\
\hline Constant & $\begin{array}{l}-0.400 \\
(-0.05)\end{array}$ & $\begin{array}{c}-0.291^{* * * *} \\
(-5.42)\end{array}$ \\
\hline $\mathrm{R}^{2}(\%)$ & 8.2 & 20.8 \\
\hline $\mathrm{N}$ & 2,466 & 2,466 \\
\hline IND_FE & YES & YES \\
\hline YEAR_FE & YES & YES \\
\hline
\end{tabular}

Table 3.14 shows the OLS regression results for moderating impact of firm age on the relationship between voting wedge and financial constraints from 2002 to 2018 . The test variable is V_WEDGE. Variable definitions are provided in Table 3.1.t-values are shown in parentheses (robust SE). $* * *, * *$ and $*$ represent significance levels of $1 \%, 5 \%$ and $10 \%$, respectively. 
TABLE 3.15: Results for the moderating impact of firm age

\begin{tabular}{|c|c|c|}
\hline FIN_CONS & $\begin{array}{c}\text { KZ_INDEX } \\
\text { Coef. } \\
\text { ( t-value) }\end{array}$ & $\begin{array}{c}\text { WW_INDEX } \\
\text { Coef. } \\
\text { ( t-value) }\end{array}$ \\
\hline INSIDER_SH & $\begin{array}{l}5.181 \\
(1.17)\end{array}$ & $\begin{array}{l}-0.010 \\
(-0.60)\end{array}$ \\
\hline AGE & $\begin{array}{c}0.263^{* * *} \\
(2.21)\end{array}$ & $\begin{array}{c}-0.001^{* * * *} \\
(-3.39)\end{array}$ \\
\hline INSIDER_SH*AGE & $\begin{array}{l}-0.172 \\
(-1.02)\end{array}$ & $\begin{array}{c}0.002^{* * * *} \\
(3.00)\end{array}$ \\
\hline CR_DUMMY & $\begin{array}{c}7.068^{* * *} \\
(4.41)\end{array}$ & $\begin{array}{c}-0.073^{* * *} \\
(-8.96)\end{array}$ \\
\hline RD_DUMMY & $\begin{array}{c}-12.620^{* * *} \\
(-5.05)\end{array}$ & $\begin{array}{c}-0.055^{* * *} \\
(-5.86)\end{array}$ \\
\hline CAPITAL_INT & $\begin{array}{l}7.968 \\
(0.76)\end{array}$ & $\begin{array}{c}-0.270^{* * *} \\
(-6.56)\end{array}$ \\
\hline ROA & $\begin{array}{c}-41.806^{* * *} \\
(-5.89)\end{array}$ & $\begin{array}{c}-0.294^{* * *} \\
(-10.47)\end{array}$ \\
\hline SALES_GROWTH & $\begin{array}{l}2.954 \\
(0.58)\end{array}$ & - \\
\hline MTB & $\begin{array}{l}-0.275 \\
(-0.06)\end{array}$ & $\begin{array}{l}-0.002 \\
(-0.09)\end{array}$ \\
\hline Constant & $\begin{array}{l}0.335 \\
(0.04)\end{array}$ & $\begin{array}{c}-0.287^{* * * *} \\
(-5.33)\end{array}$ \\
\hline $\mathrm{R}^{2}(\%)$ & 8.10 & 21.2 \\
\hline $\mathrm{N}$ & 2,466 & 2,466 \\
\hline IND_FE & YES & YES \\
\hline YEAR_FE & YES & YES \\
\hline
\end{tabular}

Table 3.15 shows the OLS regression results for the moderating impact of firm age on the relationship between the proximity of superior shareholder and financial constraints from 2002 to 2018. The test variable is INSIDER_SH. Variable definitions are provided in Table 3.1. t-values are shown in parentheses (robust SE). ***, ** and * represent significance levels of $1 \%, 5 \%$ and $10 \%$, respectively. 


\subsubsection{The BLM Index as a Measure of Financial Constraints}

Hypotheses 1-6 were also tested using the BLM index as the measure of financial constraints.

Bodnaruk et al. (2015) argue that the more managers are concerned about future financial constraints, the more they will disclose this concern through text in the 10-K. To compile a list of 184 constraint-related words from all 10-K filings, Bodnaruk et al. (2015), therefore, propose a different method from the previous indexes ${ }^{35}$ through a text-based approach, the BLM index, which uses words such as: required, obligations, impairment, covenants, etc. These 184 words, were considered by examining all words appearing in at least $5 \%$ of all 10-Ks studied, and the words were judged to be relevant to constraints if, in the majority of cases, the words indicate a constraint meaning in the context of the $10 \mathrm{~K}$.

The authors argue that this textual-analysis-based measure indicates when a particular company might suddenly face financial constraints attributable to different financial shocks and, thus, have greater explanatory power than the previous measures used in the literature, which are all based on firms' observable characteristics. The authors demonstrate that the frequency of use of these words explains subsequent liquidity events, such as dividend omissions, equity recycling, and underfunded pensions. The index reflects the proportion of constraint-related words in the $10-\mathrm{K}$ filing. The values of the index are obtained

\footnotetext{
${ }^{35} \mathrm{KZ}$, WW and SA indexes, which used firm-level characteristics to determine financial constraints.
} 
from the author's website. ${ }^{36}$ The sample selection process was discussed in Section 3.3.2 above.

The results (not reported) of testing hypotheses 1 to 3 , with financial constraints measured by the BLM index, show that the coefficients on the measures of dualclass share structure were not significant. Similarly, for the tests of hypotheses 4 to 6 , the coefficients on the interaction variables were not significant and, thus, there was no evidence to support a moderating role for the GFC.

\subsection{Conclusion}

The study examines the impact of share structure, in particular dual-class, on financial constraints for US firms over the period 2002 to 2018 . The study finds that if financial constraints are measured by the KZ, WW and SA indexes, then whether dual class structure is measured by the existence of dual-class itself or by voting wedge, the results show that, consistent with $\mathrm{H}_{1}$ and $\mathrm{H}_{2}$, dual-class share structure increases financial constraints. However, where proximity of the superior class shareholders is used as the measure of dual class, then only the results for the WW index supports $\mathrm{H}_{3}$ that financial constraints increase with a dual-class structure. These findings, overall, support the expectation that dualclass firms are more constrained than other firms.

Consistent with $\mathrm{H}_{4}$ to $\mathrm{H}_{6}$, where financial constraints are measured by the WW index, the study finds that the impact on constraints is less during the years of the financial crisis, thus, providing support for the propping theory proposed by

\footnotetext{
${ }^{36}$ https://sraf.nd.edu/data/
} 
Friedman et al., (2003). However, where financial constraints are measured by the SA index, the findings show that the impact on constraints is stronger during the GFC years. Therefore, the results for $\mathrm{H}_{4}$ to $\mathrm{H}_{6}$ can be described as mixed.

In the additional tests, the HM index scores were used to analyse variation in the impact of dual class structures according to the type of financial constraints, and the findings show that the impact on financial constraints appears to be driven by the effect on debt constraints. The study finds evidence for firm age having a moderating impact on the impact of dual class share structures if financial constraints are measured by the WW index. However, there was no evidence of a moderating effect of firm age if financial constraints are measured by the $\mathrm{KZ}$ index. The study also tested for an impact of dual class structures if financial constraints are measured by the BLM index but there was no evidence of a significant impact.

The study contributes to an emerging body of research. This study also has broader practical implications, as it could help an understanding of the effect of the potential for conflict between superior class shareholders and other shareholders in a typical economic environment, as well as during a period of a financial crisis. Furthermore, the hand-collected dataset on dual-class firms and the values of their voting wedge and the proximity of superior class shareholders, may be useful to other researchers in their examination of the topics explored here and in related topics. 
Several limitations of the study are acknowledged. The sample used for the study included only US firms, and the results can, therefore, be generalized only to similar country settings, that is, developed countries with high investor protection. Future research could consider the moderating impact of corporate governance on the association between dual-class share structure and financial constraints. Also, future research could consider the impact of multiple class share structures. 


\section{CHAPTER FOUR}

\section{CONCLUSION TO THE THESIS}

\subsection{Introduction}

This thesis addresses two aspects of financial constraints, firstly, the impact of financial constraints on firm performance and, secondly, the impact of dual-class share structure on financial constraints. In the first study, discussed in Chapter 2, meta-analysis is used to analyse the impact of financial constraints on firm performance. The second study, discussed in Chapter 3, examines the impact of dual-class share structure on financial constraints, where the share structure is measured by the existence of a dual-class share structure and also by excess voting rights and the proximity of superior class shareholders in dual-class structures.

This final chapter of the thesis proceeds as follows. Section 4.2 provides a summary of the research findings. Section 4.3 discusses the contributions of the study and Section 4.4 outlines the limitations of the study. Section 4.5 concludes the chapter with discussion of opportunities for future research.

\subsection{Summary of Research Findings}

This section provides a brief summary of the research questions and results for the studies discussed in chapters 2 and 3. 


\subsubsection{Chapter 2 Research Question}

In chapter 2 , the study addresses the research question,

"What is the overall impact of financial constraints on firm performance?"

The study uses meta-analysis to address this research question, and also uses meta-regression to examine the possible factors that cause inconsistencies in empirical studies. The results from analysing 26 empirical studies with 189 effect sizes show that, overall, there is a positive relationship between financial constraints and firm performance. In addition, the study finds that the mixed results in empirical studies appear to be attributable to the measure choice, regional difference, journal quality, and publication status. The study shows that the set of market-based measures of firm performance has a significant negative impact on the relationship compared with the set of accounting-based measures. In terms of the financial constraints measure, the external financial constraints measure has a significant positive impact on the relationship.

\subsubsection{Chapter 3: Research Question}

In chapter 3, the study addresses the research questions:

"What is the overall impact of dual-class share structures on financial constraints? Does the impact change during the global financial crisis period?"

The study examines a sample of non-financial US firms from the period 2002 to 2018. The study finds that if financial constraints are measured by the KZ, 
WW and SA indexes, then whether measured by the existence of dual-class share structure or the voting wedge, the result illustrates that dual-class share structure increases financial constraints. Regarding the proximity of the superior class shareholder, only WW index supports that financial constraints increase with the proximity of the superior class shareholders of dual-class firms. These findings support the expectation that dual-class firms are more constrained than other firms.

Additionally, if financial constraints are measured by the WW index, the study finds that the impact on constraints is less during the years of the financial crisis, thus, providing support for the propping theory proposed by Friedman et al., (2003). However, if financial constraints are measured by the SA index the findings show that the impact on constraints is stronger during the GFC years. Therefore, the impact of financial crisis shows mixed results for different measurement choices.

In the additional tests, where the HM index is used to test the different dimensions of financial constraints, the findings show that the impact on financial constraints appears to be driven by the effect on debt constraints. The study also shows that firm age has a moderating role in the impact of dual-class share structure on financial constraints where financial constraints are measured by the WW index, which supports the findings of Bebchuk and Kastiel (2017) that dual-class firms tend to increase agency costs over time. The study also includes the test for an impact of dual-class structures on financial constraints if 
financial constraints are measured by BLM index, but no evidence of an impact is found.

\subsection{Contribution and Implications of the Thesis}

Financial constraints are a relatively growing area of research. Thus, the thesis makes contributions in several aspects. The contributions are explained below in two different sections for the two studies:

For the first study, the meta-analysis offers comprehensive evidence on the impact of financial constraints on firm performance. It provides an objective summary measure. The meta-analysis provides evidence for researchers wishing to understand the importance of access to finance. The study also contribute to the meta-analysis literature by providing a further application of methodology that is still relatively uncommon in accounting and finance. Overall, the study provides information to regulators on the impact of financial constraints on performance.

The study of the relationship between complex ownership structures and financial constraints has, to date, received little attention by researchers. The study, thus, contributes to an emerging body of research. The study also has a broader implication, as it could help researchers and practitioners to understand the conflict between superior class shareholders and other shareholders, and the effect of this conflict in a typical economic environment, as well as during a period of financial crisis. These insights also contributing to an understanding of the severity of the separation of cash flow and control rights, and the size of the excess voting rights. Furthermore, the hand-collected dataset on dual-class firms 
and the values of their voting wedge and proximity of superior class shareholders, may be useful to other researchers in their examination of the topics explored here and other related topics.

Overall, the thesis contributes to the general literature and debates on financial constraints.

\subsection{Limitations of the Study}

The limitations of this study steam from three sources. First, the use of metaanalysis is subject to criticism for combining apples and oranges as it combines results from different empirical studies which use different measures and research designs and test different hypotheses. This limitation is mitigated by using the meta-regression to test the heterogeneity and focusing on only the impact of financial constraints on firm performance. The meta-analysis study also uses random effects rather than fixed effects and includes controls for factors that may cause the empirical studies to differ. A second limitation of meta-analysis is that it combines results from studies that differ in quality, as indicated by the quality of the journals in which the studies were published. However, excluding some studies, because they were published in lower ranked journals, increases the 'file drawer' problem, detracts from the objectivity of meta-analysis, and adds to difficulties in replication. It is also important to notice that a high proportion of the sample studies examined US firms, and focused on a relatively small number of papers. However, this could not be mitigated as the studies could be collected only if publicly available. 
Lastly, the research on the impact of dual-class share structure only focused on US listed firms, and the result can be generalized to similar country settings only (developed countries with stronger investor protection). In addition, the study uses only the popular and more recent index measures of financial constraints, whereas other indexes could be used for comparison. Multiple class share structures and financial institutions were excluded from this study, which could be an interesting addition for future research.

\subsection{Future Research}

Additional studies focusing on recent evidence on financial constraints are needed as new indexes have been introduced for their measurement. It is noted that a high proportion of the sample studies examined US firms, and focused on relatively short sample periods. Future research should provide additional evidence from different countries to enable decisions to be made based on the evidence unique to a particular country setting. Furthermore, given the importance of financial constraints, further study on the different dimensions of financial constraints is necessary. Future research could also be conducted to look into the moderating impact of corporate governance on the association between dual-class share structure and access to finance. It will also be interesting to analyse multiple class share structure and financial institutions separately to investigate the impact.

The conclusion from the first study is that, overall, financial constraints have a positive impact on firm performance. The conclusion from the second study is that, overall, dual-class share structures have a positive impact on financial 
constraints. Therefore, future research could address the question of whether there are links between dual-class share structure and firm performance, with financial constraints as a possible intervening variable. 


\section{REFERENCES}

Aghion, P., Fally, T., \& Scarpetta, S. (2007). Credit constraints as a barrier to the entry and post-entry growth of firms. Economic policy, 22(52), 732779.

Ahmed, K., \& Courtis, J. (1999). Associations between corporate characteristics and disclosure levels in annual reports: A meta-analysis, The British Accounting Review, 31(1), 35-61.

Ahmed, K., Chalmers, K., \& Khlif, H. (2013). A Meta-analysis of IFRS Adoption Effects, The International Journal of Accounting, 48(2), 173217.

Almeida, H., \& Campello, M. (2007). Financial constraints, asset tangibility, and corporate investment. The Review of Financial Studies, 20(5), 1429-1460.

Almeida, H., Campello, M., \& Weisbach, M. S. (2004). The cash flow sensitivity of cash. The journal of finance, 59(4), 1777-1804.

Álvarez, R., \& Bertin, M. J. (2016). Banking competition and firm-level financial constraints in Latin America. Emerging Markets Review, 28, 89104.

Ang, J. S., Cole, R. A., and Lin, J. W. (2000). Agency costs and ownership structure. The Journal of Finance, 55(1), 81-106.

Aslan, H., \& Kumar, P. (2009). Controlling shareholders and the agency cost of debt: Evidence from syndicated loans. In EFA 2009 Bergen Meeting. DOI10.2139/ssrn.1334886 
Baker, M., Stein, J. C., \& Wurgler, J. (2003). When does the market matter? Stock prices and the investment of equity-dependent firms. The Quarterly Journal of Economics, 118(3), 969-1005.

Baños-Caballero, S., García-Teruel, P. J., \& Martínez-Solano, P. (2014). Working capital management, corporate performance, and financial constraints. Journal of Business Research, 67(3), 332-338.

Bavarsad, B., Sinaei, H., \& Delavaripour, J. (2013). Study on the relationship between financial constraints and stock return in tehran stock exchange. International Journal of Economy, Management and Social Sciences, 2(5), 166-183.

Beaver, W. H., Correia, M., \& McNichols, M. F. (2011). Financial statement analysis and the prediction of financial distress. Foundations and Trends in Accounting, 5(2), 99-173.

Bebchuk, L. A., \& Kastiel, K. (2017). The untenable case for perpetual dualclass stock. Va. L. Rev., 103, 585.

Becchetti, L., \& Trovato, G. (2002). The determinants of growth for small and medium sized firms. The role of the availability of external finance. Small business economics, 19(4), 291-306.

Bentel, K., \& Walter, G. (2016). Dual Class Shares. Comparative Corporate Governance and Financial Regulation, Seminar Paper 2, Presented at Penn Law: Legal Scholarship Repository. Retrieve from http://scholarship.law.upenn.edu/fisch_2016/2 
Billett, M. T., \& Mauer, D. C. (2003). Cross-subsidies, external financing constraints, and the contribution of the internal capital market to firm value. The Review of Financial Studies, 16(4), 1167-1201.

Bloch, F., \& Hege, U. (2003). Multiple shareholders and control contests. Available at SSRN 2273211.

Bodnaruk, A., Loughran, T., \& McDonald, B. (2015). Using 10-k text to gauge financial constraints. Journal of Financial and Quantitative Analysis, 50(4), 623-646.

Bond, S. R., \& Söderbom, M. (2013). Conditional investment-cash flow sensitivities and financing constraints. Journal of the European Economic Association, 11(1), 112-136.

Borenstein, M., Hedges, L., \& Rothstein, H. (2007). Meta-analysis: Fixed effect vs. random effects. Meta-analysis.com.

Borisova, G., \& Brown, J. R. (2013). R\&D sensitivity to asset sale proceeds: New evidence on financing constraints and intangible investment. Journal of Banking \& Finance, 37(1), 159-173.

Braun, M., \& Larrain, B. (2005). Finance and the business cycle: international, inter-industry evidence. The Journal of Finance, 60(3), 1097-1128.

Brunnermeier, M. K., (2009). Deciphering the Liquidity and Credit Crunch 2007-2008. Journal of Economic Perspectives, 23(1), 77-100.

Buehlmaier, M. M., \& Whited, T. M. (2018). Are financial constraints priced? Evidence from textual analysis. The Review of Financial Studies, 31(7), 2693-2728. 
Campello, M., \& Chen, L. (2010). Are financial constraints priced? Evidence from firm fundamentals and stock returns. Journal of Money, Credit and Banking, 42(6), 1185-1198.

Carpenter, R. E., \& Petersen, B. C. (2002). Is the growth of small firms constrained by internal finance? Review of Economics and statistics, 84(2), 298-309.

Chan, H., Chang, X., Faff, R., \& Wong, G. (2010). Financial constraints and stock returns-Evidence from Australia. Pacific-Basin Finance Journal, 18(3), 306-318.

Chari, A., Chen, W., \& Dominguez, K. M. (2012). Foreign ownership and firm performance: Emerging market acquisitions in the United States. IMF Economic Review, 60(1), 1-42.

Chaudhuri, R., \& Seo, H. (2012). An agency theory explanation of SEO underperformance: Evidence from dual-class firms. Journal of International Financial Markets, Institutions, and Money, 22(3), 575-588.

Chen, I. (2016). Literature Review for Firm's Financial Constraints. Retrieve from http://asiair.asia.edu.tw/ir/handle/310904400/96954

Chen, K. C., Chen, Z., and Wei, K. J. (2009). Legal protection of investors, corporate governance, and the cost of equity capital. Journal of Corporate Finance, 15(3), 273-289.

Chen, S. S., \& Wang, Y. (2012). Financial constraints and share repurchases. Journal of Financial Economics, 105(2), 311-331. 
Chen, Y., Hua, X., \& Boateng, A. (2017). Effects of foreign acquisitions on financial constraints, productivity and investment in R\&D of target firms in China. International Business Review, 26(4), 640-651.

Cheng, B., Ioannou, I., \& Serafeim, G. (2014). Corporate social responsibility and access to finance. Strategic Management Journal, 35(1), 1-23.

Chirinko, R. S., \& Schaller, H. (1995). Why does liquidity matter in investment equations?. Journal of Money, Credit and Banking, 27(2), 527-548.

Claessens, S., Djankov, S., \& Lang, L. H. (2000). The separation of ownership and control in East Asian corporations. Journal of Financial Economics, 58(1), 81-112.

Cleary, S. (1999). The relationship between firm investment and financial status. The Journal of Finance, 54(2), 673-692.

Cleary, S. (2006). International corporate investment and the relationships between financial constraint measures. Journal of Banking \& Finance, 30(5), 1559-1580.

Cleary, S., Povel, P., \& Raith, M. (2007). The U-shaped investment curve: Theory and Evidence. Journal of Financial and Quantitative Analysis, 42(1), 1-39.

Cooper, R., \& Ejarque, J. (2003). Financial frictions and investment: requiem in q. Review of Economic Dynamics, 6(4), 710-728.

Dal Maso, L., Mazzi, F., Soscia, M., \& Terzani, S. (2018). The moderating role of stakeholder management and societal characteristics in the relationship 
between corporate environmental and financial performance. Journal of Environmental Management, 218, 322-332.

Demsetz, H., \& Villalonga, B. (2001). Ownership structure and corporate performance. Journal of corporate finance, 7(3), 209-233.

Denis, D. J., \& Sibilkov, V. (2010). Financial constraints, investment, and the value of cash holdings. The Review of Financial Studies, 23(1), 247-269.

Devereux, M., \& Schiantarelli, F. (1990). Investment, financial factors, and cash flow: Evidence from UK panel data. In Asymmetric information, corporate finance, and investment (pp. 279-306). University of Chicago Press.

Djankov, S., La Porta, R., Lopez-de-Silanes, F., \& Shleifer, A. (2008). The law and economics of self-dealing. Journal of Financial Economics, 88(3), 430-465.

Duchin, R., Ozbas, O., \& Sensoy, B. A. (2010). Costly external finance, corporate investment, and the subprime mortgage credit crisis. Journal of Financial Economics, 97(3), 418-435.

Duval, S., \& Tweedie, R. (2000). A nonparametric "trim and fill" method of accounting for publication bias in meta-analysis, Journal of the American Statistical Association, 95(449), 89-98.

Eichengreen, B., \& O'rourke, K. H. (2009). A tale of two depressions. VoxEU. org, 1 .

Eigner, P., \& Umlauft, T. S. (2015). The Great Depression (s) of 1929-1933 and 2007-2009? Parallels, Differences and Policy Lessons. Parallels, 
Differences and Policy Lessons (July 1, 2015). Hungarian Academy of Science MTA-ELTE Crisis History Working Paper, (2).

Erickson, T., \& Whited, T. M. (2000). Measurement error and the relationship between investment and q. Journal of political economy, 108(5), 10271057.

Erkens, D. H., Hung, M., \& Matos, P. (2012). Corporate governance in the 20072008 financial crisis: Evidence from financial institutions worldwide. Journal of Corporate Finance, 18(2), 389-411.

Farre-Mensa, J., \& Ljungqvist, A. (2016). Do measures of financial constraints measure financial constraints?. The Review of Financial Studies, 29(2), 271-308.

Fazzari, S. M., Hubbard, R. G., Petersen, B. C., Blinder, A. S., \& Poterba, J. M. (1988). Financing constraints and corporate investment. Brookings Papers on Economic Activity, 1(1), 141-206.

Firth, M., Fung, P. M., \& Rui, O. M. (2006). Firm performance, governance structure, and top management turnover in a transitional economy. Journal of Management Studies, 43(6), 1289-1330.

Friedman, E., Johnson, S., \& Mitton, T. (2003). Propping and tunneling. Journal of Comparative Economics, 31(4), 732-750.

Gardiol, L., Gibson-Asner, R., \& Tuchschmid, N. S. (1997). Are liquidity and corporate control priced by shareholders? Empirical evidence from Swiss dual class shares. Journal of Corporate Finance, 3(4), 299-323. 
Gertler, M., \& Gilchrist, S. (1994). Monetary policy, business cycles, and the behavior of small manufacturing firms. The Quarterly Journal of Economics, 109(2), 309-340.

Gilchrist, S., \& Himmelberg, C. P. (1995). Evidence on the role of cash flow for investment. Journal of Monetary Economics, 36(3), 541-572.

Gompers, P. A., Ishii, J., \& Metrick, A. (2009). Extreme governance: An analysis of dual-class firms in the United States. The Review of Financial Studies, 23(3), 1051-1088.

Grossman, S. J., \& Hart, O. D. (1988). One share-one vote and the market for corporate control. Journal of Financial Economics, 20, 175-202.

Habib, A. (2012). Non-audit service fees and financial reporting quality: A meta-analysis. Abacus, 48(2), 214-248.

Hadlock, C. J., \& Pierce, J. R. (2010). New evidence on measuring financial constraints: Moving beyond the $\mathrm{KZ}$ index. The Review of Financial Studies, 23(5), 1909-1940.

Hahn, J., \& Lee, H. (2009). Financial constraints, debt capacity, and the crosssection of stock returns. The Journal of Finance, 64(2), 891-921.

Haider, Z. A., Liu, M., Wang, Y., \& Zhang, Y. (2018). Government ownership, financial constraint, corruption, and corporate performance: International evidence. Journal of International Financial Markets, Institutions and Money, 53, 76-93. 
Hay, D. C., \& Knechel, W. R. (2017). Meta-regression in auditing research: Evaluating the evidence on the Big $\mathrm{N}$ audit firm premium. Auditing: A Journal of Practice \& Theory, 36(2), 133-159.

Hay, D. C., Knechel, R. W., \& Wong, N. (2006). Audit fees: a meta-analysis of the effect of supply and demand attributes. Contemporary Accounting Research, 23(1), 141-191.

Heller, S. (2015). Financial Constraints and Corporate Credit Ratings: Essays in Corporate Finance and Risk Management (Doctoral dissertation, Staats-und Universitätsbibliothek Hamburg Carl von Ossietzky).

Hennessy, C. A., \& Whited, T. M. (2007). How costly is external financing? Evidence from a structural estimation. The Journal of Finance, 62(4), $1705-1745$.

Hennessy, C. A., Levy, A., \& Whited, T. M. (2007). Testing Q theory with financing frictions. Journal of Financial Economics, 83(3), 691-717.

Higgins, J. P. T., Thompson, S. G., Deeks, J. J., \& Altman, D. G. (2003). Measuring inconsistency in meta-analyses. BMJ: British Medical Journal, $327(7414), 557-560$.

Hoberg, G., \& Maksimovic, V. (2014). Redefining financial constraints: A textbased analysis. The Review of Financial Studies, 28(5), 1312-1352.

Hoi, C. K., \& Robin, A. (2010). Agency conflicts, controlling owner proximity, and firm value: An analysis of dual-class firms in the United States. Corporate Governance: An International Review, 18(2), 124-135. 
Hong, H. A., Kim, J. B., \& Welker, M. (2017). Divergence of cash flow and voting rights, opacity, and stock price crash risk: international evidence. Journal of Accounting Research, 55(5), 1167-1212.

Howell, J. W. (2010). The dual class stock structure in the United States (Doctoral dissertation, uga).

Jensen, M. C., and Meckling, W. H. (1976). Theory of the firm: Managerial behavior, agency costs and ownership structure. Journal of Financial Economics, 3(4), 305-360.

Jin, Y., Luo, M., \& Wan, C. (2018). Financial constraints, macro-financing environment and post-crisis recovery of firms. International Review of Economics \& Finance, 55, 54-67.

Jog, V. M., \& Riding, A. L. (1986). Price effects of dual-class shares. Financial Analysts Journal, 42(1), 58-67.

Junzheng, S. (2016). The Anatomy of Dual Class Share Structures: A Comparative Perspective. Hong Kong LJ, 46, 477.

Kadapakkam, P. R., Kumar, P. C., \& Riddick, L. A. (1998). The impact of cash flows and firm size on investment: The international evidence. Journal of Banking \& Finance, 22(3), 293-320.

Kale, A., Maigari, B., \& Haruna, H. (2017). Economic Recession in Nigeria: Implications for Nursing Education and Practice. IOSR Journal of Nursing and Health Science, 6(02), 54-62. 
Kaplan, S. N., \& Zingales, L. (1997). Do investment-cash flow sensitivities provide useful measures of financing constraints?. The Quarterly Journal of Economics, 112(1), 169-215.

Khatami, S. H., Marchica, M. T., \& Mura, R. (2015). Corporate acquisitions and financial constraints. International Review of Financial Analysis, 40, 107121.

Khlif, H., \& Chalmers, K. (2015). A review of meta-analytic research in accounting. Journal of Accounting Literature, 35, 1-27.

Kim, H. J., \& Yoon, S. S. (2007). Corporate governance and firm performance in Korea. Management \& Accounting Review (MAR), 6(2), 1-16.

Knapp, G., \& Hartung, J. (2003). Improved tests for a random effects metaregression with a single covariate. Statistics in Medicine, 22(17), 26932710.

La Porta, R., Lopez-de-Silanes, F., Shleifer, A., \& Vishny, R. (2000). Investor protection and corporate governance. Journal of Financial Economics, 58(1-2), 3-27.

La Porta, R., Lopez-de-Silanes, F., Shleifer, A., \& Vishny, R. W. (1998). Law and finance. Journal of Political Economy, 106(6), 1113-1155.

Lamont, O., Polk, C., \& Saaá-Requejo, J. (2001). Financial constraints and stock returns. The Review of Financial Studies, 14(2), 529-554.

Le, N. (2016). When More is Less: The Impact of Large Cash Holdings on the Recovery of Firms' Performance. Available at SSRN 2150645. 
Li, D. (2011). Financial constraints, R\&D investment, and stock returns. The Review of Financial Studies, 24(9), 2974-3007.

Li, X., \& Luo, D. (2019). Financial constraints, stock liquidity, and stock returns. Journal of International Financial Markets, Institutions and Money, 63, 101139.

Limanl,, Ö. (2015). Determinants of R\&D investment decision in Turkey. Procedia-Social and Behavioral Sciences, 195, 759-767.

Lin, C., Ma, Y., \& Xuan, Y. (2011a). Ownership structure and financial constraints: Evidence from a structural estimation. Journal of Financial Economics, 102(2), 416-431.

Lin, C., Ma, Y., Malatesta, P., \& Xuan, Y. (2011b). Ownership structure and the cost of corporate borrowing. Journal of Financial Economics, 100(1), 123.

Lin, Y. F., Liao, Y. C., \& Chang, K. C. (2011c). Firm performance, corporate governance and executive compensation in high-tech businesses. Total Quality Management \& Business Excellence, 22(2), 159-172.

Lipsey, M. W., \& Wilson, D. B. (2001). Practical meta-analysis. SAGE publications, Inc.

Livdan, D., Sapriza, H., \& Zhang, L. (2009). Financially constrained stock returns. The Journal of Finance, 64(4), 1827-1862.

Martínez-Sola, C., García-Teruel, P. J., \& Martínez-Solano, P. (2013). Corporate cash holding and firm value. Applied Economics, 45(2), 161-170. 
Masulis, R. W., Wang, C., \& Xie, F. (2009). Agency problems at dual-class companies. The Journal of Finance, 64(4), 1697-1727.

McConnell, J. J., \& Servaes, H. (1995). Equity ownership and the two faces of debt. Journal of Financial Economics, 39(1), 131-157.

Mercatanti, A., Mäkinen, T., \& Silvestrini, A. (2017). Investment decisions by

European firms and financing constraints (Working Paper No. 1148).

Bank of Italy

Economic Research Department. Retrieved from

http://dx.doi.org/10.2139/ssrn.3066770

Moore, T., \& Mirzaei, A. (2016). The impact of the global financial crisis on industry growth. The Manchester School, 84(2), 159-180.

Morck, R., Shleifer, A. \& Vishny, R. W. (1988). Management ownership and market valuation: An empirical analysis. Journal of Financial Economics, 20, 293-315.

Musso, P., \& Schiavo, S. (2008). The impact of financial constraints on firm survival and growth. Journal of Evolutionary Economics, 18(2), 135-149.

Myers, S. C. \& Majluf, N. S. (1984). Corporate financing and investment decisions when firms have information that investors do not have. Journal of Financial Economics, 13(2), 187-221.

Nguyen, T. L. H., Nguyen, L. N. T., \& Le, T. P. V. (2016). Firm value, corporate cash holdings and financial constraint: A study from a developing market. Australian Economic Papers, 55(4), 368-385. 
Norden, L., \& Weber, M. (2004). Informational efficiency of credit default swap and stock markets: The impact of credit rating announcements. Journal of Banking \& Finance, 28(11), 2813-2843.

O'connell, V., \& Cramer, N. (2010). The relationship between firm performance and board characteristics in Ireland. European management journal, 28(5), 387-399.

Oliveira, B., \& Fortunato, A. (2006). Firm growth and liquidity constraints: A dynamic analysis. Small Business Economics, 27(2), 139-156.

Opare, S., Houqe, N., \& van Zijl, T. (2019). Meta-Analysis of the Impact of Adoption of IFRS on Financial Reporting Comparability, Market Liquidity, and Cost of Capital. In 2019 Financial Markets \& Corporate Governance Conference.

Opler, T. C. \& Titman, S. (1994). Financial distress and corporate performance. The Journal of Finance, 49(3), 1015-1040.

Orlitzky, M., Schmidt, F. L., \& Rynes, S. L. (2003). Corporate social and financial performance: A meta-analysis. Organization Studies, 24(3), 403441.

Pellicani, A. \& Moccellin, J. (2010). The Impact of Corporate Governance on Financial Constraint: Evidence from Brazilian Firms. International Conference on Applied Economics, 389-395.

Pomeroy, B., \& Thornton, D. B. (2008). Meta-analysis and the accounting literature: The case of audit committee independence and financial reporting quality. European Accounting Review, 17(2), 305-330. 
Ringquist, E. (2013). Meta-analysis for public management and policy. John Wiley \& Sons.

Rosenthal, R. (1991). Meta-analytic procedures for social research. Applied Social Research Methods Series. Newbury Park: SAGE Publication.

Saghi-Zedek, N. \& Tarazi, A. (2015). Excess control rights, financial crisis and bank profitability and risk. Journal of Banking \& Finance, 55, 361-379.

Sasidharan, S., Lukose, P. J., \& Komera, S. (2015). Financing constraints and investments in R\&D: Evidence from Indian manufacturing firms. The Quarterly Review of Economics and Finance, 55, 28-39.

Scargle, J. D. (2000). Publication bias: The "file-drawer" problem in scientific inference. Journal of Scientific Exploration, 14(1), 91-106.

Senbet, L. W. \& Wang, T. Y. (2012). Corporate financial distress and bankruptcy: A survey. Foundations and Trends in Finance, 5(4), 243-335.

Shleifer, A. \& Vishny, R. W. (1986). Large shareholders and corporate control. Journal of Political Economy, 94(3, Part 1), 461-488.

Shleifer, A. \& Vishny, R. W. (1997). A survey of corporate governance. The Journal of Finance, 52(2), 737-783.

Smith, B. F., Amoako-Adu, B., \& Kalimipalli, M. (2009). Concentrated control and corporate value: a comparative analysis of single and dual class structures in Canada. Applied Financial Economics, 19(12), 955-974.

Stein, J. C. (2003). Agency, information and corporate investment. Handbook of the Economics of Finance, 1, 111-165. 
Stikkelman, C. (2010). The Effect of Financial Constraints on The Firm's Value of Non-Financial Publicly Traded Companies in France (Bachelor thesis). Amsterdam School of Economics, University of Amsterdam, Netherlands.

Suits, D. B. (1984). Dummy variables: Mechanics v. interpretation. The Review of Economics and Statistics, 177-180.

Temin, P. (2010). The Great Recession \& the Great Depression. Daedalus, 139(4), 115-124.

Ting, H. I. (2008). Does corporate disclosure quality help? International Research Journal of Finance and Economics, 21(21), 150-157.

Tobin, J. (1969). A general equilibrium approach to monetary theory. Journal of Money, Credit and Banking, 1(1), 15-29.

van Essen, M., Carney, M., Gedajlovic, E. R., \& Heugens, P. P. (2015). How does family control influence firm strategy and performance? A metaanalysis of US publicly listed firms. Corporate Governance: An International Review, 23(1), 3-24.

Wang, K. \& Shailer, G. (2015). Ownership concentration and firm performance in emerging markets: A meta-analysis. Journal of Economic Surveys, 29(2), 199-229.

Wang, K. T., \& Shailer, G. (2018). Does ownership identity matter? A metaanalysis of research on firm financial performance in relation to government versus private ownership. Abacus, 54(1), 1-35.

Wei, G. (2007). Ownership structure, corporate governance and company performance in China. Asia Pacific Business Review, 13(4), 519-545. 
Wei, K. J. \& Zhang, Y. (2008). Ownership structure, cash flow, and capital investment: Evidence from East Asian economies before the financial crisis. Journal of Corporate Finance, 14(2), 118-132.

Whited, T. M. \& Wu, G. (2006). Financial constraints risk. The Review of Financial Studies, 19(2), 531-559.

Whited, T. M. (1992). Debt, liquidity constraints, and corporate investment: Evidence from panel data. The Journal of Finance, 47(4), 1425-1460.

Whited, T. M. (2006). External finance constraints and the intertemporal pattern of intermittent investment. Journal of Financial Economics, 81(3), 467502.

Winker, P. (1999). Causes and effects of financing constraints at the firm level. Small Business Economics, 12(2), 169-181.

Xu, L. C., Zhu, T., \& Lin, Y. (2005). Politician control, agency problems and ownership reform: Evidence from China. Economics of Transition, 13(1), $1-24$.

Zhao, T., \& Xiao, X. (2019). The impact of corporate social responsibility on financial constraints: Does the life cycle stage of a firm matter? International Review of Economics \& Finance, 63, 76-93.

Zhao, W. (2016). Corporate Governance, Financial Constraint, and Value of Cash Holdings: Research from the Perspective of Ultimate Controllers. Modern Economy, 7(10), 1096-1119. DOI: 10.4236/me.2016.710111 